Prepared in cooperation with the Washington State Department of Ecology and Kittitas County

\title{
Hydrogeologic Framework and Groundwater/Surface-Water Interactions of the Upper Yakima River Basin, Kittitas County, Central Washington
}

Scientific Investigations Report 2014-5119 
Cover: View of upper Yakima River Basin from South Cle Elum Ridge, south of Roslyn, Washington, looking northwest; Cle Elum and Kachess Lakes in background. Photograph taken by James D. Patterson, U.S. Geological Survey, June 25, 2014. 


\section{Hydrogeologic Framework and Groundwater/Surface-Water Interactions of the Upper Yakima River Basin, Kittitas County, Central Washington}

By Andrew S. Gendaszek, D. Matthew Ely, Stephen R. Hinkle, Sue C. Kahle, and Wendy B. Welch

Prepared in cooperation with the Washington State Department of Ecology and Kittitas County

Scientific Investigations Report 2014-5119 


\title{
U.S. Department of the Interior SALLY JEWELL, Secretary
}

\section{U.S. Geological Survey Suzette M. Kimball, Acting Director}

\author{
U.S. Geological Survey, Reston, Virginia: 2014
}

For more information on the USGS - the Federal source for science about the Earth, its natural and living resources, natural hazards, and the environment, visit http://www.usgs.gov or call 1-888-ASK-USGS.

For an overview of USGS information products, including maps, imagery, and publications, visit http://www.usgs.gov/pubprod

To order this and other USGS information products, visit http://store.usgs.gov

Any use of trade, firm, or product names is for descriptive purposes only and does not imply endorsement by the U.S. Government.

Although this information product, for the most part, is in the public domain, it also may contain copyrighted materials as noted in the text. Permission to reproduce copyrighted items must be secured from the copyright owner.

Suggested citation:

Gendaszek, A.S., Ely, D.M., Hinkle, S.R., Kahle, S.C., and Welch, W.B., 2014, Hydrogeologic framework and groundwater/surface-water interactions of the upper Yakima River Basin, Kittitas County, central Washington: U.S. Geological Survey Scientific Investigations Report 2014-5119, 66 p., http://dx.doi.org/10.3133/sir20145119.

ISSN 2328-0328 (online) 


\section{Contents}

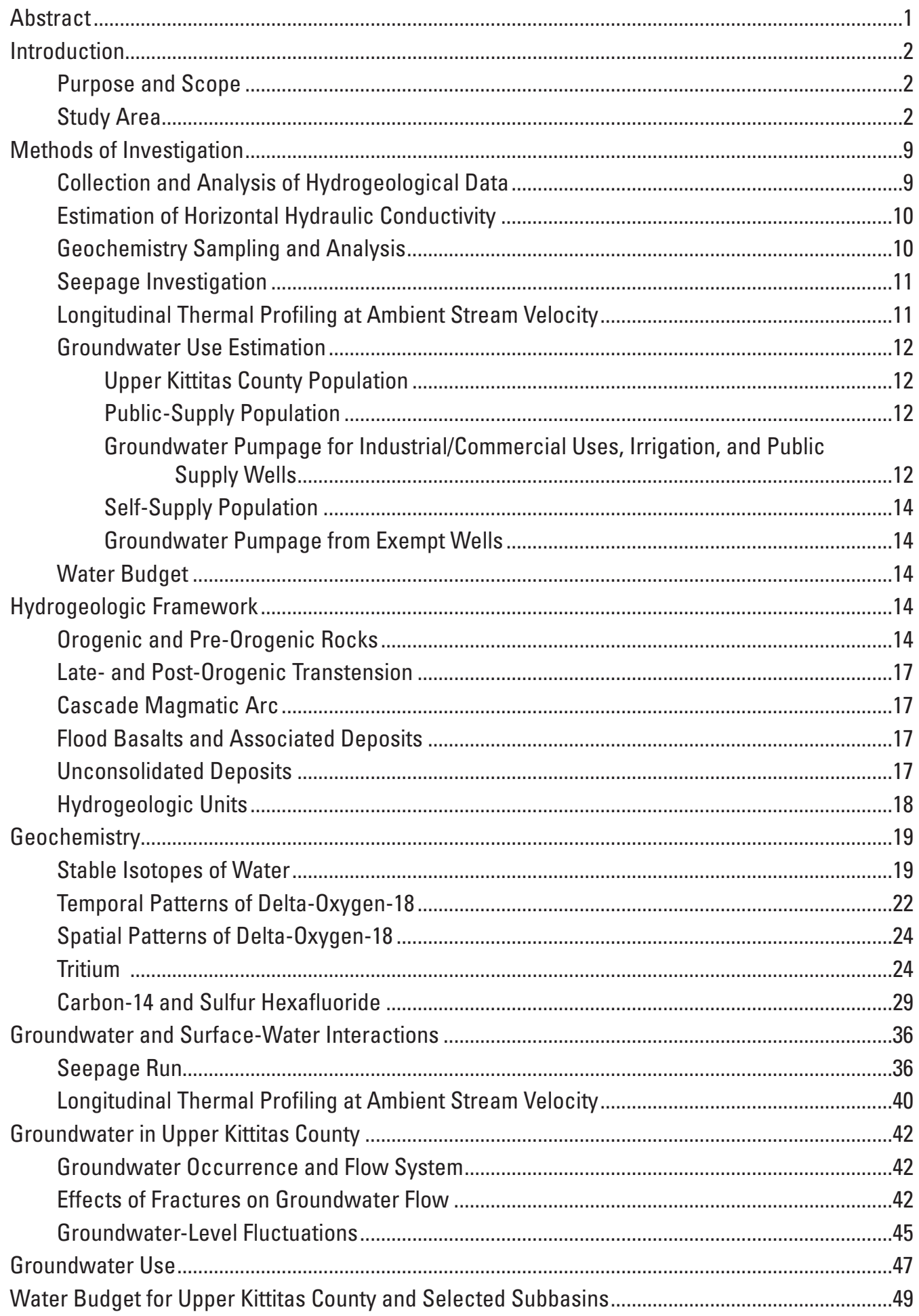




\section{Contents-Continued}

Potential Effects of Groundwater Withdrawals on Surface-Water Features...................................52

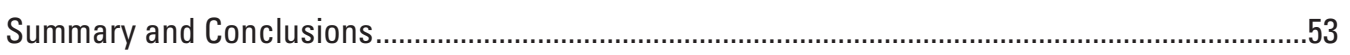

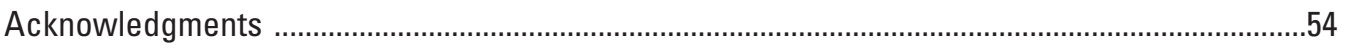

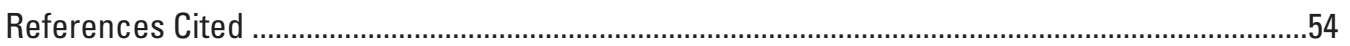

Glossary

\section{Plates}

[Available for download as a PDF at http://pubs.usgs.gov/sir/2014/5119]

1. Geologic map and location of project wells and springs in upper Yakima River Basin, Kittitas County, central Washington.

2. Hydrogeologic unit map and cross sections in the upper Yakima River Basin, Kittitas County, central Washington.

\section{Figures}

1. Map showing study area in upper Yakima River Basin, Kittitas County, central Washington .3

2. Map showing upper Yakima River Basin, Kittitas County, central Washington .4

3. Graphs showing mean monthly streamflow for Yakima River at Cle Elum and Teanaway River near Cle Elum, upper Yakima River Basin, Kittitas County, central Washington, water years 1995-2013.

4. Graphs showing mean monthly streamflow during a dry year (water year 1997), and a wet year (water year 2002), Yakima River at Cle Elum, upper Yakima River Basin, Kittitas County, central Washington

5. Map showing land use and land cover in upper Yakima River Basin, Kittitas County, central Washington, 2006.

6. Map showing distribution of population by census block for upper Yakima River Basin, Kittitas County, central Washington, during 2010

7. Map showing subbasins from a Precipitation Runoff Modeling System watershed model of upper Yakima River Basin, Kittitas County, Washington.

8. Map showing regional geologic setting of the upper Yakima River Basin, Kittitas County, Washington

9. Map showing groundwater, surface-water, precipitation, and spring sites sampled for chemical and isotopic constituents in upper Yakima River Basin, Kittitas County, central Washington, 2010-12..

10. Graph showing stable isotope (hydrogen, $\boldsymbol{\delta}^{2} \mathrm{H}$; oxygen, $\boldsymbol{\delta}^{18} \mathrm{H}$ ) data for wells, springs, small streams, and precipitation samples from upper Yakima River Basin, Kittitas County, central Washington, 2010-12

11. Graphs showing temporal variability in stable-isotopic oxygen-18 $\left(\boldsymbol{\delta}^{18} 0\right)$ and tritium $\left({ }^{3} \mathrm{H}\right)$ values at well 19N/14E-02C01 in the fractured phyllite aquifer unit, upper Yakima River Basin, Kittitas County, central Washington. 


\section{Figures-Continued}

12. Map showing spatial distribution of oxygen isotope $\left(\boldsymbol{\delta}^{18} 0\right)$ values in samples collected from wells in upper Yakima River Basin, Kittitas County, central Washington, water years 2011-12.

13. Map showing spatial distribution of oxygen isotope $\left(\boldsymbol{\delta}^{18} 0\right)$ values in samples collected from springs, upper Yakima River Basin, Kittitas County, central Washington, July-September 2012

14. Map showing spatial distribution of oxygen isotope $\left(\delta^{18} 0\right)$ values in samples collected from small streams, upper Yakima River Basin, Kittitas County, central Washington, August 2011 ..

15. Graph showing reconstructed tritium input function for the upper Yakima River Basin, Kittitas County, central Washington

16. Graphs showing vertical distribution of tritium concentrations from all samples, unconsolidated sediment, sedimentary rocks, and flood basalt and other volcanic, metamorphic, and intrusive rocks in water samples collected from wells, upper Yakima River Basin, Kittitas County, central Washington, 2011-12.

17. Map showing gaining, near-neutral, and losing reaches measured during August 2011 seepage run, upper Yakima River Basin, Kittitas County, central Washington.

18. Map showing longitudinal temperature profile at North Fork Teanaway River on September 6, 2012, upper Yakima River Basin, Kittitas County, central Washington......40

19. Map showing longitudinal temperature profile at Big Creek on September 7, 2012, upper Yakima River Basin, Kittitas County, central Washington

20. Graph showing longitudinal temperature profile at ambient flow velocity at North Fork Teanaway River on September 6, 2012, Yakima River Basin, Kittitas County, central Washington

21. Graph showing longitudinal temperature profile at ambient flow velocity at Big Creek on September 7, 2012, Kittitas County, central Washington

22. Map showing potentiometric surface and generalized flow directions in hydrogeologic units, upper Yakima River Basin, Kittitas County, central Washington...43

23. Scatter plot showing hydraulic conductivity in fractured bedrock as estimated over increasingly larger physical dimensions from discrete-interval, single hole hydraulic tests, cross-hole hydraulic tests, and regional groundwater-flow models, Mirror Lake watershed and vicinity, New Hampshire.

24. Diagram showing hypothesized distribution of fractures having high transmissivity in the rock underlying the well field; the intervals of high-transmissivity fractures are connected only by less transmissive fractures

25. Graphs showing water levels in wells 20N/16E-30C01 and 19N/15E-08B02, upper Yakima River Basin, Kittitas County, central Washington, May 2012-April 2013

26. Map showing dasymetric estimates of population using self-supplied (domestic private well) water for upper Yakima River Basin, Kittitas County, central Washington, 2010

27. Graphs showing mean annual and mean monthly water budget components for modeled subbasins for upper Yakima River Basin, Kittitas County, central Washington. 


\section{Tables}

1. Bureau of Reclamation streamflow-gaging stations within upper Yakima River Basin, Kittitas County, Central Washington.

2. Hydrogeologic units, well yields, and estimated hydraulic conductivity in upper Yakima River Basin, Kittitas County, central Washington.

3. Carbon-isotope data, selected chemical and other isotopic data, and selected ancillary data for sites that were sampled for carbon isotopes, upper Yakima River Basin, Kittitas County, central Washington, 2012.

4. Gains and losses for seepage investigation reaches, upper Yakima River Basin, Kittitas County, central Washington, August 2011

5. Statistical summary of water-level fluctuations and well depth by hydrogeologic unit, upper Yakima River Basin, Kittitas County, central Washington, May 2012April 2013.

6. Population and estimated population served by public supply and domestic exempt wells, upper Yakima River Basin, Kittitas County, central Washington, 2000 and 2010

7. Selected physical and hydrologic data for wells, upper Yakima River Basin, Kittitas County, central Washington.

\section{Conversion Factors, Datums, Supplemental Information, and Well Numbering System \\ Conversion Factors}

\begin{tabular}{|c|c|c|}
\hline Multiply & By & To obtain \\
\hline \multicolumn{3}{|c|}{ Length } \\
\hline inch (in.) & 2.54 & centimeter (cm) \\
\hline inch (in.) & 25.4 & millimeter (mm) \\
\hline foot (ft) & 0.3048 & meter $(\mathrm{m})$ \\
\hline mile (mi) & 1.609 & kilometer (km) \\
\hline \multicolumn{3}{|c|}{ Area } \\
\hline acre & 4,047 & square meter $\left(\mathrm{m}^{2}\right)$ \\
\hline acre & 0.004047 & square kilometer $\left(\mathrm{km}^{2}\right)$ \\
\hline square mile $\left(\mathrm{mi}^{2}\right)$ & 2.590 & square kilometer $\left(\mathrm{km}^{2}\right)$ \\
\hline \multicolumn{3}{|c|}{ Volume } \\
\hline acre-foot (acre-ft) & 1,233 & cubic meter $\left(\mathrm{m}^{3}\right)$ \\
\hline \multicolumn{3}{|c|}{ Flow rate } \\
\hline acre-foot per year (acre-ft/yr) & 1,233 & cubic meter per year (m³/yr) \\
\hline cubic foot per second $\left(\mathrm{ft}^{3} / \mathrm{s}\right)$ & 0.02832 & cubic meter per second $\left(\mathrm{m}^{3} / \mathrm{s}\right)$ \\
\hline $\begin{array}{l}\text { cubic foot per second per square } \\
\text { mile }\left[\left(\mathrm{ft}^{3} / \mathrm{s}\right) / \mathrm{mi}^{2}\right]\end{array}$ & 0.01093 & $\begin{array}{l}\text { cubic meter per second per square } \\
\text { kilometer }\left[\left(\mathrm{m}^{3} / \mathrm{s}\right) / \mathrm{km}^{2}\right]\end{array}$ \\
\hline cubic foot per day $\left(\mathrm{ft}^{3} / \mathrm{d}\right)$ & 0.02832 & cubic meter per day $\left(\mathrm{m}^{3} / \mathrm{d}\right)$ \\
\hline gallon per minute (gal/min) & 0.06309 & liter per second $(\mathrm{L} / \mathrm{s})$ \\
\hline inch per year (in/yr) & 25.4 & millimeter per year (mm/yr) \\
\hline \multicolumn{3}{|c|}{ Hydraulic conductivity } \\
\hline foot per day (ft/d) & 0.3048 & meter per day $(\mathrm{m} / \mathrm{d})$ \\
\hline \multicolumn{3}{|c|}{ Transmissivity* } \\
\hline foot squared per day ( $\left.\mathrm{ft}^{2} / \mathrm{d}\right)$ & 0.09290 & meter squared per day (m²/d) \\
\hline
\end{tabular}




\section{Conversion Factors, Datums, Supplemental Information, and Well Numbering System-Continued}

Temperature in degrees Celsius $\left({ }^{\circ} \mathrm{C}\right)$ may be converted to degrees Fahrenheit $\left({ }^{\circ} \mathrm{F}\right)$ as follows:

$$
{ }^{\circ} \mathrm{F}=\left(1.8 x^{\circ} \mathrm{C}\right)+32 \text {. }
$$

Temperature in degrees Fahrenheit $\left({ }^{\circ} \mathrm{F}\right)$ may be converted to degrees Celsius $\left({ }^{\circ} \mathrm{C}\right)$ as follows:

$$
{ }^{\circ} \mathrm{C}=\left({ }^{\circ} \mathrm{F}-32\right) / 1.8 \text {. }
$$

*Transmissivity: The standard unit for transmissivity is cubic foot per day per square foot times foot of aquifer thickness [(ft $\left.\left.{ }^{3} / \mathrm{d}\right) / \mathrm{ft}^{2}\right] \mathrm{ft}$. In this report, the mathematically reduced form, foot squared per day $\left(\mathrm{ft}^{2} / \mathrm{d}\right)$, is used for convenience.

Specific conductance is given in microsiemens per centimeter at 25 degrees Celsius $(\mu \mathrm{S} / \mathrm{cm}$ at $\left.25^{\circ} \mathrm{C}\right)$.

Concentrations of most chemical constituents in water are given either in milligrams per liter $(\mathrm{mg} / \mathrm{L})$ or micrograms per liter $(\mu \mathrm{g} / \mathrm{L})$. Sulfur hexafluoride $\left(\mathrm{SF}_{6}\right)$ concentrations are given in units of femtograms per kilogram $(\mathrm{fg} / \mathrm{kg})$; one femtogram is $10^{-15} \mathrm{gram}$.

\section{Datums}

Vertical coordinate information is referenced to the North American Vertical Datum of 1988 (NAVD 88).

Horizontal coordinate information is referenced to the North American Datum of 1983 (NAD 83).

Altitude, as used in this report, refers to distance above the vertical datum.

\section{Supplemental Information}

Stable isotopes of water are reported as $\boldsymbol{\delta}$ values computed from the formula

$$
\delta=\left[\left(\frac{R_{x}}{R_{S T D}}\right)-1\right] 1000
$$

where

$$
\begin{aligned}
& R_{x} \text { is the ratio of }{ }^{2} \mathrm{H} \text { to }{ }^{1} \mathrm{H} \text { or }{ }^{18} \mathrm{O} \text { to }{ }^{16} \mathrm{O} \text { in the sample; } \\
& R_{\text {STD }} \text { is the }{ }^{2} \mathrm{H} \text { to }{ }^{1} \mathrm{H} \text { or }{ }^{18} \mathrm{O} \text { to }{ }^{16} \mathrm{O} \text { ratio of the reference standard Vienna Standard Mean } \\
& \text { Ocean Water (VSMOW); and }
\end{aligned}
$$

$\delta^{2} \mathrm{H}$ or $\boldsymbol{\delta}^{18} \mathrm{O}$ is expressed in parts per thousand (\%).

Stable isotopes of carbon are reported as $\boldsymbol{\delta}$ values computed from the formula

$$
\delta=\left[\left(\frac{R_{x}}{R_{S T D}}\right)-1\right] 1000
$$

where

$R_{x}$ is the ratio of ${ }^{13} \mathrm{C}$ to ${ }^{12} \mathrm{C}$ in the sample;

$R_{\text {STD }}$ is the ${ }^{13} \mathrm{C}$ to ${ }^{12} \mathrm{C}$ ratio of the reference standard Vienna Peedee Belemnite; and $\delta^{13} \mathrm{C}$ is expressed in parts per thousand. 


\section{Conversion Factors, Datums, Supplemental Information, and Well Numbering System-Continued}

\section{Well-Numbering System}

In Washington, wells are assigned numbers that identify their location within a township, range, section, and 40-acre tract. Number 19N/14E-01A03 indicates that the well is in Township 19 North and Range 14 East, north and east of the Willamette Base Line and Meridian, respectively. The numbers immediately following the hyphen indicate the section (01) within the township; the letter following the section gives the 40 -acre tract of the section. The two-digit sequence number (03) following the letter indicates that the well was the first third inventoried by project personnel in that 40 -acre tract. $A$ " $D$ " following the sequence number indicates that the well has been deepened. In the illustrations of this report, wells are identified individually by only the section and 40-acre tract, such as 01A03; township and range are shown on the map borders.

$\mathrm{T}$.

\begin{tabular}{|c|c|c|c|c|c|c|c|c|c|c|}
\hline 6 & 5 & 4 & 3 & 2 & 1 & & & & & \\
\hline 7 & & & & & 12 & & & & & \\
\hline 18 & & & & & 12 & & D & c & B & $A^{\bullet}$ \\
\hline 10 & & & & & 15 & & E & $\mathrm{F}$ & G & H \\
\hline 19 & & & & & 24 & & M & $\mathrm{L}$ & $\mathrm{K}$ & $\mathrm{J}$ \\
\hline 30 & & & & & 25 & & N & & 0 & $\mathrm{R}$ \\
\hline 31 & 32 & 33 & 34 & 35 & 36 & & \multicolumn{4}{|c|}{ SECTION 01} \\
\hline
\end{tabular}

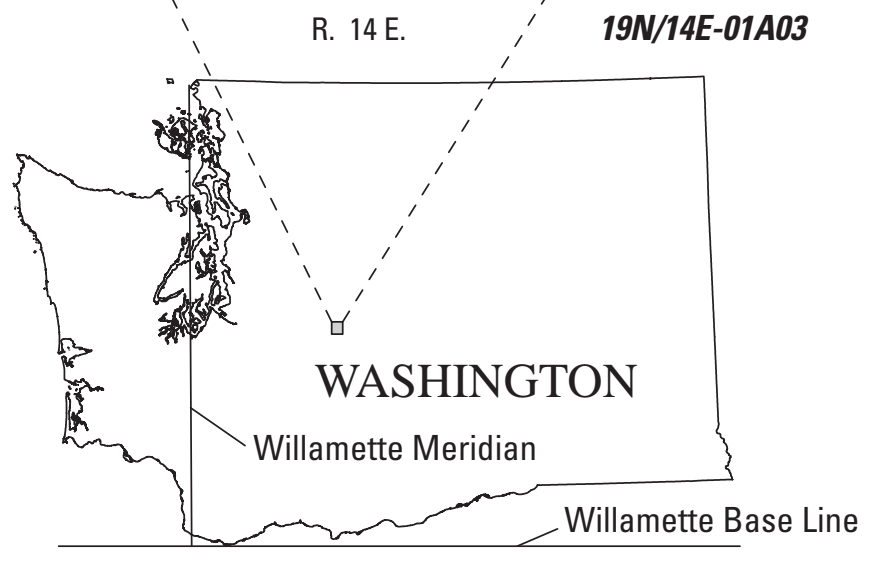




\title{
Hydrogeologic Framework and Groundwater/Surface- Water Interactions of the Upper Yakima River Basin, Kittitas County, Central Washington
}

\author{
By Andrew S. Gendaszek, D. Matthew Ely, Stephen R. Hinkle, Sue C. Kahle, and Wendy B. Welch
}

\section{Abstract}

The hydrogeology, hydrology, and geochemistry of groundwater and surface water in the upper (western) 860 square miles of the Yakima River Basin in Kittitas County, Washington, were studied to evaluate the groundwater-flow system, occurrence and availability of groundwater, and the extent of groundwater/surface-water interactions. The study area ranged in altitude from 7,960 feet in its headwaters in the Cascade Range to 1,730 feet at the confluence of the Yakima River with Swauk Creek. A west-to-east precipitation gradient exists in the basin with the western, high-altitude headwaters of the basin receiving more than 100 inches of precipitation per year and the eastern, low-altitude part of the basin receiving about 20 inches of precipitation per year. From the early 20th century onward, reservoirs in the upper part of the basin (for example, Keechelus, Kachess, and Cle Elum Lakes) have been managed to store snowmelt for irrigation in the greater Yakima River Basin. Canals transport water from these reservoirs for irrigation in the study area; additional water use is met through groundwater withdrawals from wells and surface-water withdrawals from streams and rivers. Estimated groundwater use for domestic, commercial, and irrigation purposes is reported for the study area.

A complex assemblage of sedimentary, metamorphic, and igneous bedrock underlies the study area. In a structural basin in the southeastern part of the study area, the bedrock is overlain by unconsolidated sediments of glacial and alluvial origin. Rocks and sediments were grouped into six hydrogeologic units based on their lithologic and hydraulic characteristics. A map of their extent was developed from previous geologic mapping and lithostratigraphic information from drillers' logs. Water flows through interstitial space in unconsolidated sediments, but largely flows through fractures and other sources of secondary porosity in bedrock. Generalized groundwater-flow directions within the unconfined part of the aquifers in unconsolidated sediments indicate generalized groundwater movement toward the Yakima River and its tributaries and the outlet of the study area.
Groundwater movement through fractures within the bedrock aquifers is complex and varies over spatial scales depending on the architecture of the fracture-flow system and its hydraulic properties. The complexity of the fracturedbedrock groundwater-flow system is supported by a wide range of groundwater ages determined from geochemical analyses of carbon-14, sulfur hexafluoride, and tritium in groundwater. These geochemical data also indicate that the shallow groundwater system is actively flushing with young, isotopically heavy groundwater, but isotopicallylight, Pleistocene-age groundwater with a geochemicallyevolved composition occurs at depth within the fracturedbedrock aquifers of upper Kittitas County. An eastward depletion of stable isotopes in groundwater is consistent with hydrologically separate subbasins. This suggests that groundwater that recharges in one subbasin is not generally available for withdrawal or discharge into surface-water features within other subbasins. Water budget components were calculated for 11 subbasins using a watershed model and varied based on the climate, land uses, and geology of the subbasin.

Synoptic streamflow measurements made in August 2011 indicate that groundwater discharges into several tributaries of the Yakima River with several losses of streamflow measured where the streams exit bedrock uplands and flow over unconsolidated sediments. Profiles of stream temperature during late summer suggest cool groundwater inflow over discrete sections of streams. This groundwater/surfacewater connection is further supported by the stable-isotope composition of stream water, which reflects the local stableisotope composition of groundwater measured at some wells and springs.

Collectively, these hydrogeologic, hydrologic, and geochemical data support a framework for evaluating the potential effects of future groundwater appropriations on senior surface-water and groundwater rights and streamflows. Although total pumping rates in upper Kittitas County of about 3.5 cubic feet per second are small relative to other components of the water budget, the magnitude, timing, and location of withdrawals may have important effects on the 
hydrologic system. The heterogeneous and variably fractured bedrock in the study area precluded a detailed evaluation of localized effects of pumping, but several generalizations about the groundwater and surface-water systems can be made. These generalizations include evidence for the continuity between the groundwater and surface-water system apparent from synoptic streamflow measurements, stream-temperature profiles, and stable-isotope data of groundwater and surface waters.

\section{Introduction}

Surface water in the Yakima River Basin in Kittitas County, central Washington (fig. 1) is considered overallocated by water managers, with junior surface-water users who obtained their water rights after senior surface-water users having entitlements 'prorated' in below average runoff years. Since 1945, junior water users have been prorated at least 14 percent of the time. In turn, since about 1960, new water demands have been met by the use of groundwater, and almost all of these uses hold a priority date for withdrawals that is later than surface-water users. As a result, in 2007 a private organization in Kittitas County submitted a petition to the Washington State Department of Ecology (WaDOE) that requested unconditional withdraws of future appropriations of groundwater in Kittitas County until sufficient information is known about potential effects of groundwater withdrawals on streamflow and senior surface-water and groundwater rights. The unconditional withdrawal was rejected by WaDOE and negotiations began for a Memorandum of Agreement with Kittitas County, which included a provision to study the groundwater resources of the western (upper) part of Kittitas County that mainly consists of the bedrock-floored, upland area (fig. 2). The groundwater resources for the remaining part of the county were analyzed as part of a Yakima River Basin water availability study (Vaccaro and others, 2009; Ely and others, 2011) conducted by the U.S. Geological Survey (USGS). As of October 2010, an emergency rule was in effect that established a withdrawal from appropriation of all unappropriated groundwater in upper Kittitas County (Washington Administrative Code 173-539A-010).

\section{Purpose and Scope}

Four objectives for the groundwater study of upper Kittitas County were developed by Kittitas County, WaDOE, and other parties to address concerns about the overallocation of water resources in upper Kittitas County and the potential effects of additional groundwater withdrawals on existing water users and streamflows. These objectives include: (1) define the hydrogeologic framework of the study area; (2) provide information regarding occurrence and availability of groundwater; (3) describe the potential extent of groundwater and surface-water interactions; and (4) determine the potential effects of groundwater withdrawals on surface-water features. These goals were addressed through diverse hydrogeologic, hydrologic, and geochemical approaches that provided multiple lines of evidence for the occurrence and movement of groundwater through the study area and for the relation of groundwater to surface water in the study area. After the results from each of these approaches are individually presented and discussed, the potential effects of groundwater withdrawals on surface-water features are discussed by synthesizing the results from each of the approaches.

The objectives of this study were met using a four-phased approach. The first phase included project planning, coordination, and outreach; gathering, compiling, documenting, and assessing available data; initial collection of readily available data; and conducting readily achievable work elements that provide information for meeting the objectives. The second phase included the development of an initial conceptual model of the groundwater-flow system based on the information from the first phase. During the third phase, the conceptual model of the groundwater-flow system was refined and data were collected to support mapping and characterizing hydrogeologic units to the extent possible within the data limitations; mapping of groundwater levels; estimating groundwater use; developing updated estimates of groundwater recharge; and constructing water budgets for selected subbasins. Together, these items provided the information for describing the groundwater-flow system (occurrence and availability) and provided the building blocks for constructing the hydrogeologic framework and estimating the extent of groundwater and surface-water continuity and potential effects on streamflow resulting from groundwater withdrawals. In the fourth phase, study results were documented and presented in Fasser and Julich (2013), Hinkle and Ely (2013), and this report.

\section{Study Area}

The upper Kittitas County study area encompasses about 860 square miles $\left(\mathrm{mi}^{2}\right)$ of the upper (western) Yakima River Basin (fig. 2). The altitude of the study area ranges from 1,730 to 7,960 feet (ft), with a mean of 3,620 ft. Most of the precipitation falls as snow in the mountains during the winter. Mean annual precipitation of the study area is on the order of 80 inches (in.), but a west-to-east precipitation gradient exists in the basin with the western, high-elevation headwaters of the basin receiving more than 100 in. of precipitation per year and the eastern, low-elevation part of the basin receiving about $20 \mathrm{in}$. of precipitation per year. Mean temperatures averaged over the study area ranged from about $20^{\circ} \mathrm{F}$ in January and December to about $80^{\circ} \mathrm{F}$ in July and August, but varied considerably because of topographic relief and distance from the Cascade crest. 


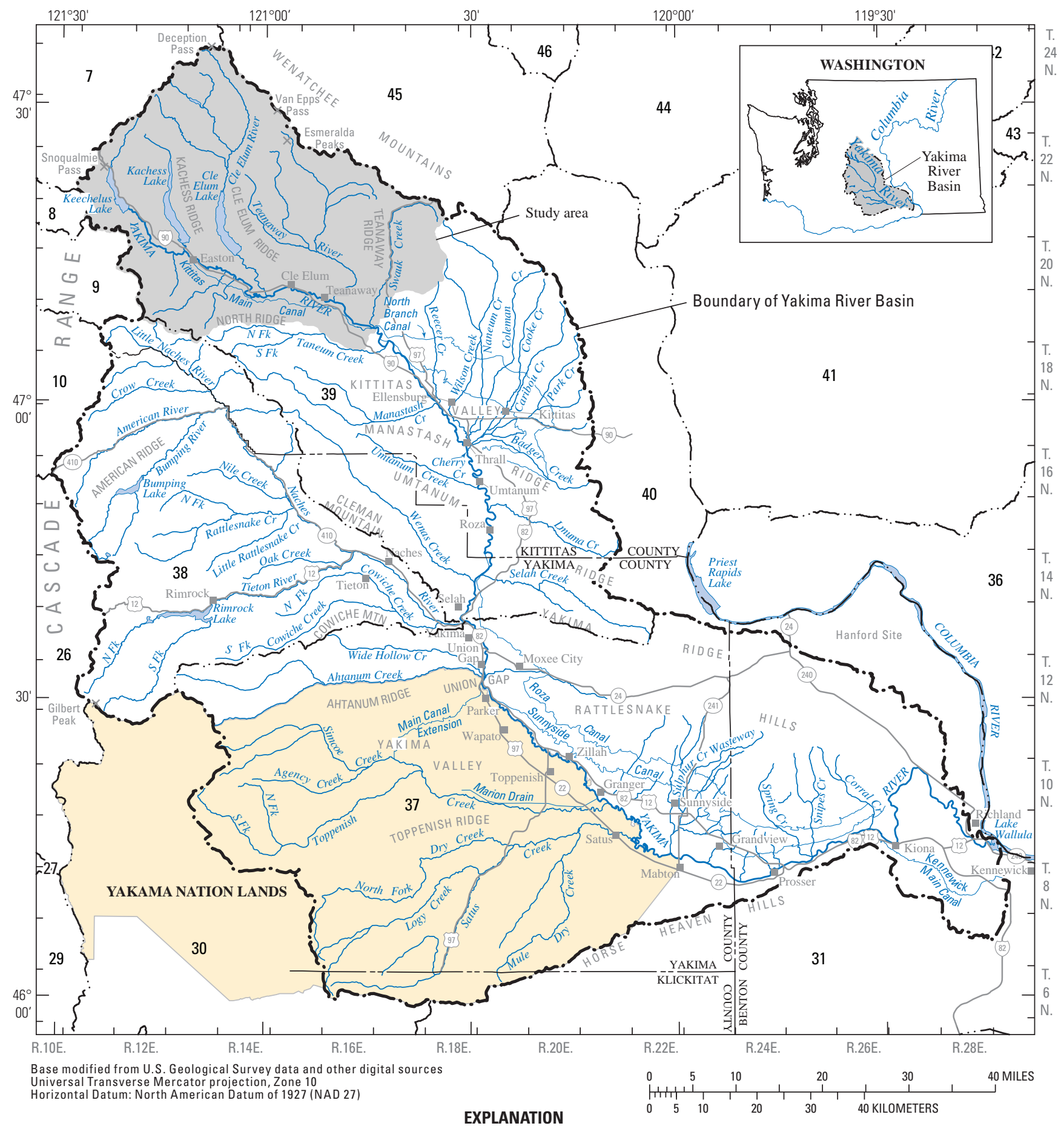

$\lceil 417$ Water Resource Inventory Areas and No.

Figure 1. Study area in upper Yakima River Basin, Kittitas County, central Washington. 


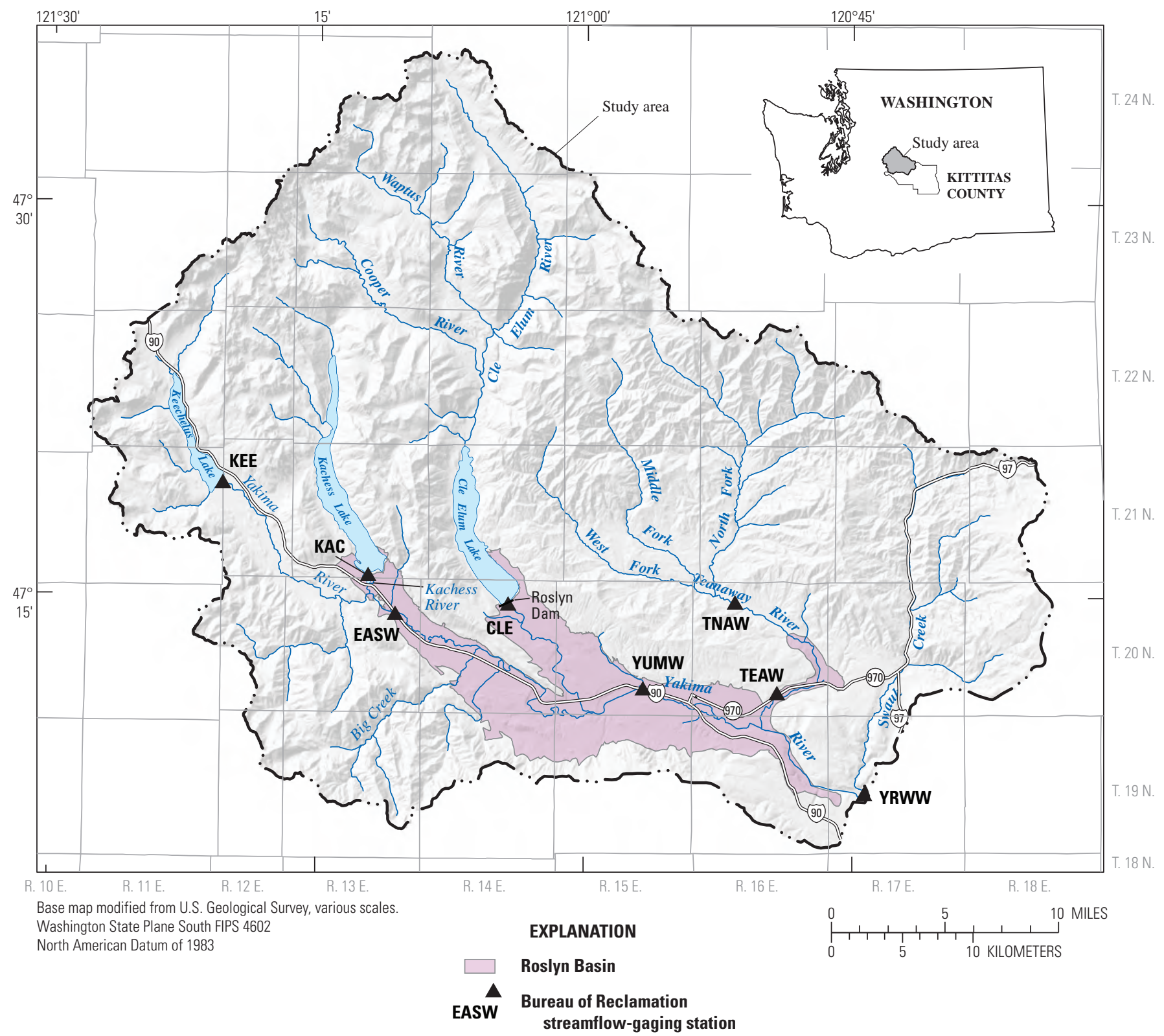

Figure 2. Upper Yakima River Basin, Kittitas County, central Washington. Abbreviations refer to streamflow-gaging stations as shown in table 1. 
Based on streamflow for the Yakima River at Cle Elum, the area generates about 2,200 cubic feet per second $\left(\mathrm{ft}^{3} / \mathrm{s}\right)$ of unregulated runoff (4.4 cubic feet per second per square mile $\left[\left(\mathrm{ft}^{3} / \mathrm{s}\right) / \mathrm{mi}^{2}\right]$ ) and $1,700 \mathrm{ft}^{3} / \mathrm{s}$ of regulated runoff (3.4 cubic feet per second per square mile $\left.\left[\left(\mathrm{ft}^{3} / \mathrm{s}\right) / \mathrm{mi}^{2}\right]\right)$. The difference results from reservoir operation and consumptive water use. The three reservoirs operated by the Bureau of Reclamation (Reclamation) in the study area account for about 78 percent of the total surface-water storage in the Yakima River Basin, which drains an area of about 6,200 $\mathrm{mi}^{2}$ and produces a mean annual unregulated streamflow (adjusted for regulation) of about 5,600 ft ${ }^{3} / \mathrm{s}$ (about 4.1 million acre-feet [acre-ft]) and a regulated streamflow of about $3,600 \mathrm{ft}^{3} / \mathrm{s}$ (about 2.6 million acre-ft). The Yakima River Basin includes three of Washington State's Water Resources Inventory Areas (numbers 37, 38, and 39), parts of three counties (Kittitas, Yakima, and Benton Counties), part of the Yakama Nation lands, and four ecoregions (Omernik, 1987; Cuffney and others, 1997). The Yakima River flows into the Columbia River in the lowlying, arid part of the basin, which receives about 6 in. of precipitation per year.

As of 2014, Reclamation operated 8 streamflow-gaging stations in the study area— 4 on the Yakima River, 2 on the Teanaway River, and 1 on the Kachess and Cle Elum Rivers (fig. 2; table 1). Several of these streamflow-gaging stations were previously operated by the USGS. Streamflow in the Yakima River and two of its tributaries, the Kachess and Cle Elum Rivers, is regulated by the operation of the Kachess, Keechelus, and Cle Elum Dams (fig. 1). These dams were constructed between 1912 and 1933, after the passage of the Federal Reclamation Act of 1902 that enabled the construction of Federal water projects to promote development in the western United States, and after the passage of the Reclamation Enabling Act by the Washington State Legislature in 1905 that authorized the Yakima Federal Reclamation Project. Facilities authorized by this project, including the dams in upper Kittitas County, were constructed to provide irrigation for 500,000 acres in the Yakima River Basin and to provide 1.07 million acre-ft of storage capacity, 78 percent of which is in upper Kittitas County (Ely and others, 2011). Surface water used for irrigation is primarily delivered by canals constructed by 1933, which are operated and maintained by the Kittitas Reclamation District. The Kittitas Reclamation District (KRD) includes about 59,000 irrigable acres, which are served by $330 \mathrm{mi}$ of canals and laterals. Individual water rights provide for additional surface-water withdrawals from streams and rivers in the study area.
Table 1. Bureau of Reclamation streamflow-gaging stations within upper Yakima River Basin, Kittitas County, Central Washington.

[Locations of streamflow-gaging stations are shown in figure 2]

\begin{tabular}{lc}
\hline \multicolumn{1}{c}{ Station name } & $\begin{array}{c}\text { Station } \\
\text { identification }\end{array}$ \\
\hline Yakima River at Martin & KEE \\
Kachess River & KAC \\
Yakima River at Easton, Washington & EASW \\
Cle Elum River & CLE \\
Yakima River at Cle Elum, Washington & YUMW \\
Teanaway River at Forks near Cle Elum, Washington & TNAW \\
Teanaway River below Lambert Road & TEAW \\
Yakima River near Horlick, Washington & YRWW \\
\hline
\end{tabular}

The operation of the dams in upper Kittitas County was affected by a 1980 Federal court decision and by title XII of Public Law 103-434, which instituted the current instreamflow regulations in 1995 for the Yakima River Basin that resulted in lower releases from reservoirs in upper Kittitas County after mid-September. As a result of flow regulation, the highest mean monthly streamflow in the Yakima River at Cle Elum between water years 1995 and 2013 occurred in August and decreased by nearly 75 percent in September (fig. 3A). A water year is defined as the 12-month period from October 1 for any given year through September 30 of the following year. In unregulated tributaries of the Yakima River such as the Teanaway River, streamflow was highest after the snowpack melted in April and May and was lowest during August and September (fig. 3B). Mean daily streamflows measured at the Yakima River at Cle Elum during wet (1997) and dry (2002) water years are shown in figure 4. The highest streamflow during wet years such as water year 1997 occurred during spring, when much of the snowmelt was passed through dams prior to late summer when reservoir releases typically occur (fig. 4A). In dry years such as water year 2002, most of the snowmelt was stored in reservoirs during spring, and the streamflows during the spring snowmelt were lower (fig. 4B).

The dominant land cover in 2006 (Fry and others, 2011) was forests (62 percent), followed by shrub and scrubland (19 percent), and grassland (7 percent; fig. 5). Developed land accounted for 4 percent of the study area, with Cle Elum and Roslyn being the largest towns in the study area. The KRD supplies surface-water irrigation along the Yakima River valley. The major crop types are hay and alfalfa. 

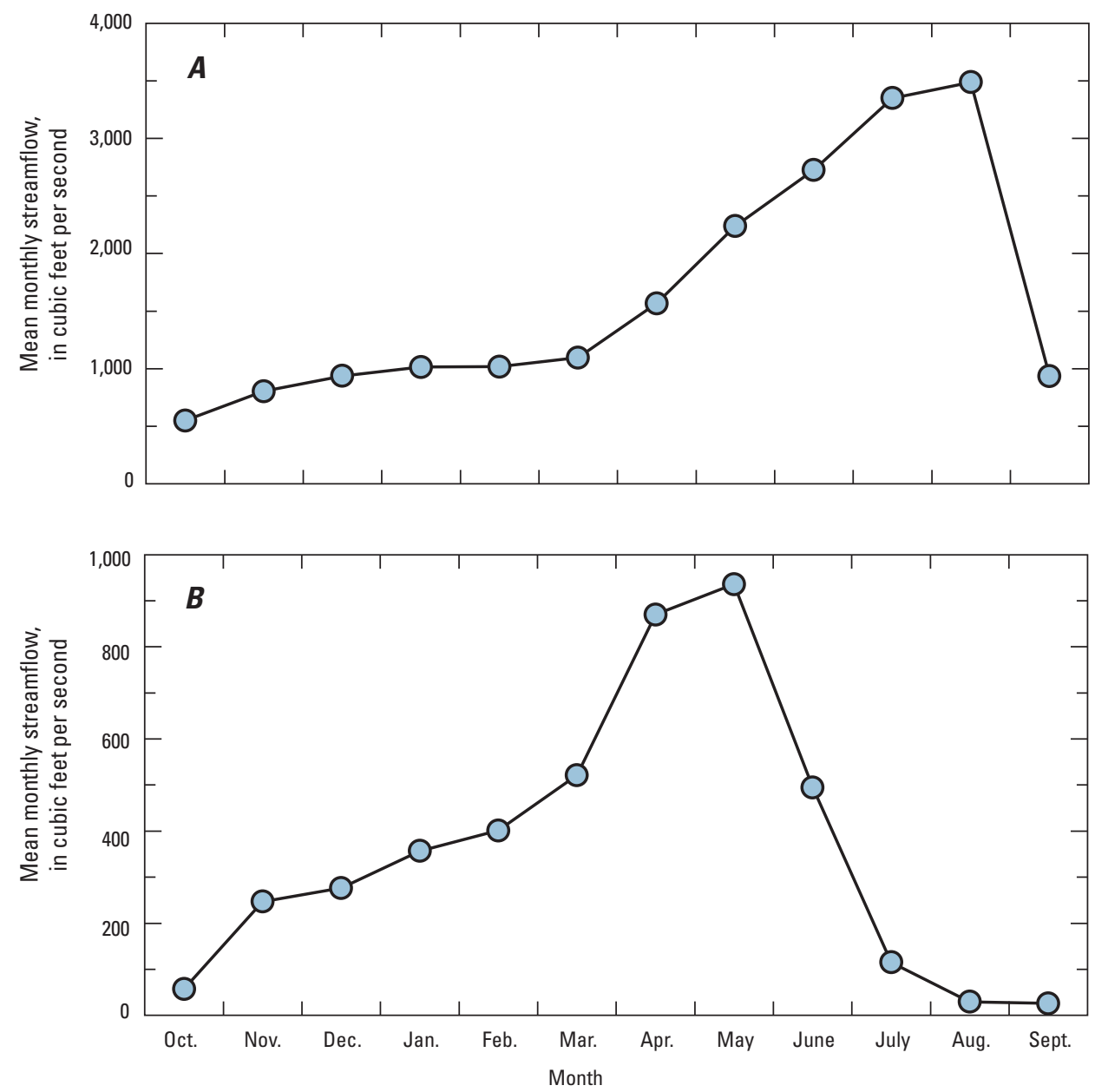

Figure 3. Mean monthly streamflow for $(A)$ Yakima River at Cle Elum and $(B)$ Teanaway River near Cle Elum, upper Yakima River Basin, Kittitas County, central Washington, water years 1995-2013. 

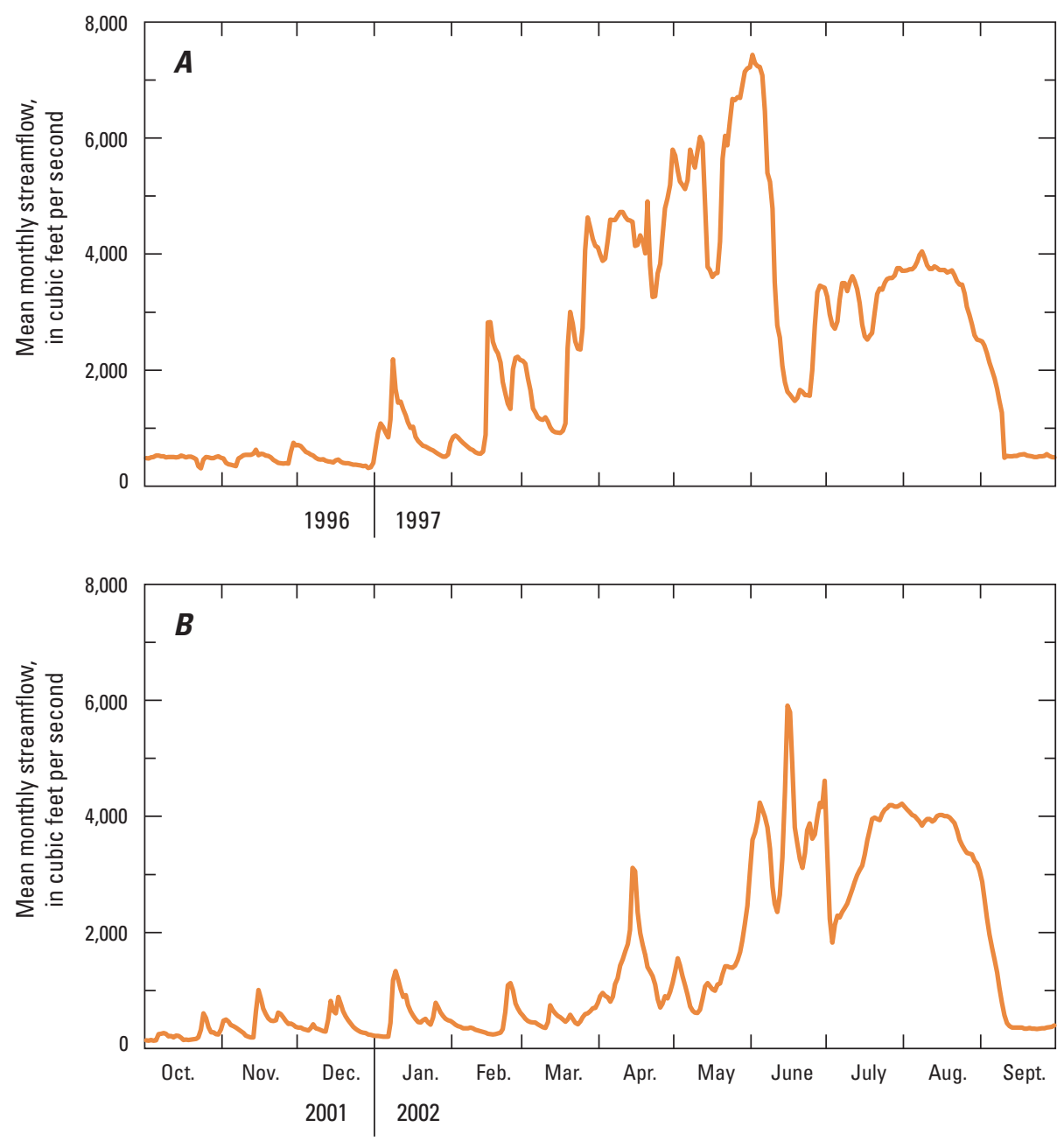

Figure 4. Mean monthly streamflow during $(A)$ a wet year (water year 1997), and $(B)$ a dry year (water year 2002), Yakima River at Cle Elum, upper Yakima River Basin, Kittitas County, central Washington. 


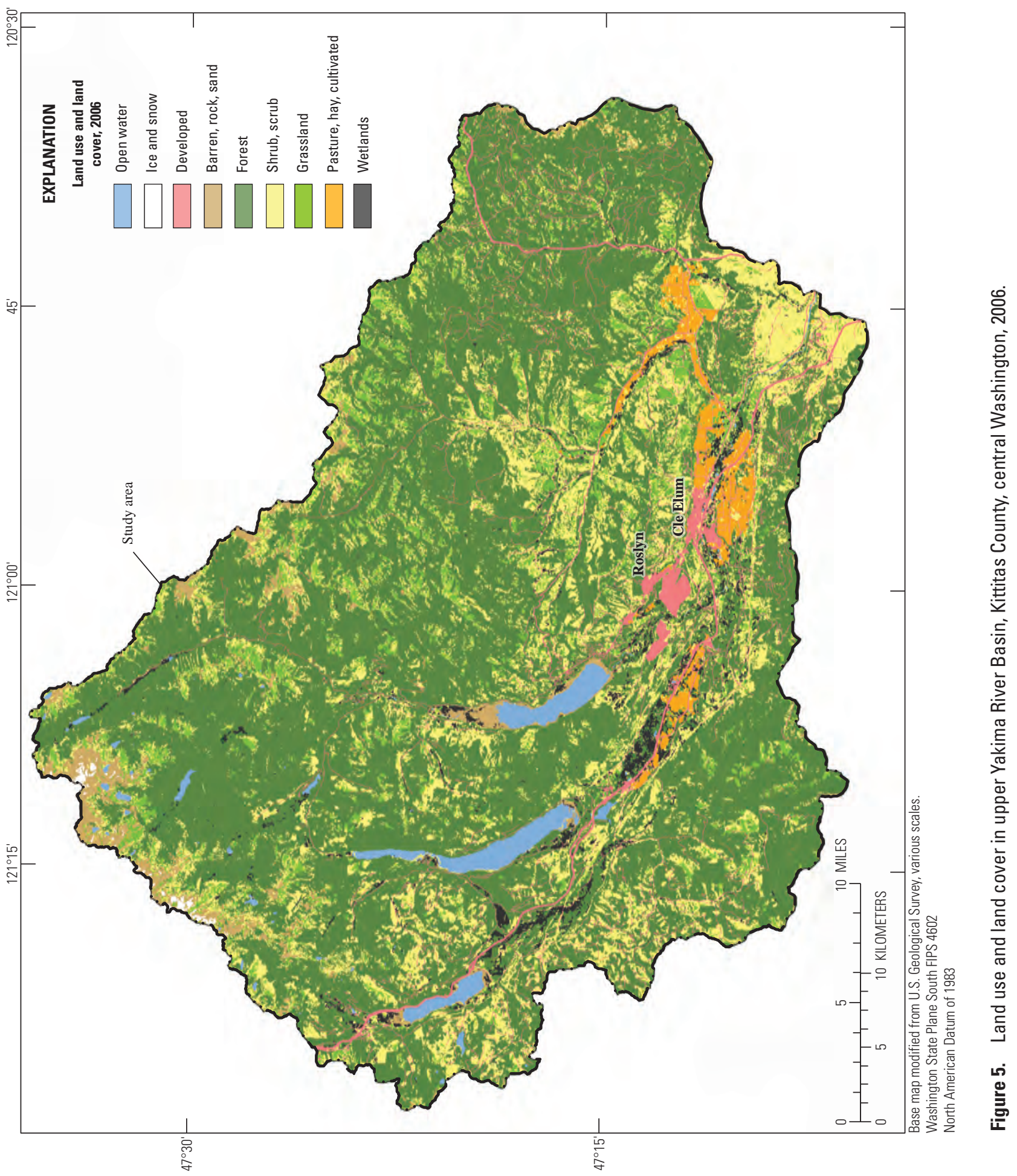




\section{Methods of Investigation}

A diverse suite of methods was used to compile and analyze the hydrogeologic, hydrologic, and geochemical data for this study. These methods were used to synthesize existing geologic and hydrogeologic data into a basin-wide hydrogeologic framework, characterize the geochemistry of groundwater and surface water, characterize groundwater and surface-water interactions, estimate groundwater use, and develop a water budget.

\section{Collection and Analysis of Hydrogeological Data}

The surficial geology for the study area was compiled from previous maps developed by Dragovich and others (2002), Brown and Dragovich (2003), Cheney and Hayman (2007), and Haugerud and Tabor (2009). A geologic map of the upper Kittitas County study area was clipped from a larger map by Haugerud and Tabor (2009) and is included on plate 1. Additional lithostratigraphic information was obtained from drillers' logs from 271 project wells; 196 of these wells were field-inventoried in April and May of 2011 (Fasser and Julich, 2011). The locations of the project wells used to describe the hydrogeology of the study area are shown on plates 1 and 2 . Selected physical and hydrologic data for the project wells are included on table 7 (at back of report).

The geologic units were grouped into six hydrogeologic units based on similar rock types, lithologic characteristics, and large-scale hydrologic properties. The hydrogeologic units described in this report include unconsolidated sediment (UNC), basalt (BAS), volcanic rocks (VOLC), sedimentary rocks (SED), metamorphic rocks (META), and intrusive rocks (INT) (table 2). The surficial extent of the units across the study area and their subsurface extent along four hydrogeologic sections are illustrated on plate 2 . The open intervals of the wells are color coded based on the hydrogeologic unit that the wells are open to. Using the hydrogeologic unit map and information contained on drillers' logs for the project wells, four hydrogeologic sections were constructed to identify and correlate hydrogeologic units, primarily on the basis of rock type and stratigraphic position (A-A' through D-D', pl. 2).

Table 2. Hydrogeologic units, well yields, and estimated hydraulic conductivity in upper Yakima River Basin, Kittitas County, central Washington.

[A bbreviations: min, minimum; max, maximum; gal/min, gallon per minute; ft/d, foot per day]

\begin{tabular}{|c|c|c|c|c|}
\hline $\begin{array}{l}\text { Hydro- } \\
\text { geologic } \\
\text { unit }\end{array}$ & Description of hydrogeologic units & $\begin{array}{l}\text { Number } \\
\text { of project } \\
\text { wells open } \\
\text { to unit }\end{array}$ & $\begin{array}{c}\text { Well yield } \\
\text { [min, median, max] } \\
\text { \{number of values\} } \\
\text { (gal/min) }\end{array}$ & $\begin{array}{c}\text { Estimated hydraulic } \\
\text { conductivity } \\
\text { [min, median, max] } \\
\text { \{number of wells\} } \\
\text { (ft/d) }\end{array}$ \\
\hline UNC & $\begin{array}{l}\text { UNCONSOLIDATED SEDIMENT_-Unconsolidated glacial } \\
\text { and non-glacial deposits; includes alluvium, talus, landslide } \\
\text { deposits, glaciolacustrine deposits, alpine glacial deposits, } \\
\text { recessional outwash, outburst flood deposits. }\end{array}$ & 67 & $\begin{array}{l}{[0,25,1,600]} \\
\quad\{53\}\end{array}$ & $\begin{array}{l}{[4.4,190,1,600]} \\
\{10\}\end{array}$ \\
\hline BAS & $\begin{array}{l}\text { Flood BASALT of the Grande Ronde and associated interbeds } \\
\text { of the Ellensburg Formation. }\end{array}$ & 9 & $\begin{array}{l}{[1,17.5,75]} \\
\{8\}\end{array}$ & $\{0\}$ \\
\hline VOLC & $\begin{array}{l}\text { VOLCANIC ROCKS_-basalt, andesite, some rhyolite, } \\
\text { breccias, tuffs of the Fifes Peak episode (Tcaf) and } \\
\text { Ohanapecosh episode (Tcao). As well as basalt and rhyolite } \\
\text { flows, breccia, and tuff intermixed with some sandstone and } \\
\text { conglomerate; Teanaway Fm; Tev. This unit also includes } \\
\text { dacite and andesite flows and pyroclastic rocks locally } \\
\text { interbedded in the Swauk Fm; Silver Pass Volcanic Member } \\
\text { of Swauk Fm. }\end{array}$ & 18 & $\begin{array}{l}{[3,18,42]} \\
\quad\{14\}\end{array}$ & $\begin{array}{c}{[0.02]} \\
\{1\}\end{array}$ \\
\hline SED & $\begin{array}{l}\text { SEDIMENTARY ROCKS—-sandstone and conglomerate with } \\
\text { subordinate shale, coal; Roslyn Fm; Tes as well as stream- } \\
\text { deposited sandstone and conglomerate; Swauk Fm; Tees. }\end{array}$ & 113 & $\begin{array}{l}{[0,10,150]} \\
\quad\{94\}\end{array}$ & $\begin{array}{l}{[1.6,2.6,3.6]} \\
\quad\{2\}\end{array}$ \\
\hline META & $\begin{array}{l}\text { METAMORPHIC ROCKS_-black phyllite, typically with } \\
\text { abundant quartz veinlets; Ked, Darrington Phyllite; fine } \\
\text { grained greenschist and (or) blueschist derived mostly from } \\
\text { ocean-floor basalt; Kes, Shuksan Greenschist. }\end{array}$ & 20 & $\begin{array}{l}{[0,3,40]} \\
\quad\{17\}\end{array}$ & $\{0\}$ \\
\hline INT & $\begin{array}{l}\text { INTRUSIVE ROCKS—peridotite and foliated and massive } \\
\text { serpentinite; Ingalls terrane, Jis. }\end{array}$ & 3 & $\begin{array}{l}{[0,5,60]} \\
\quad\{3\}\end{array}$ & $\{0\}$ \\
\hline
\end{tabular}




\section{Estimation of Horizontal Hydraulic Conductivity}

Hydraulic conductivity is a measure of the ability of a material to transmit water. Horizontal hydraulic conductivity was estimated for the hydrogeologic units using the drawdown/discharge relation reported on drillers' logs that reported pump testing wells for 4-45 hours. Data were used only from those wells with a driller's log containing discharge rate, pumping duration, drawdown, static water level, wellconstruction data, and lithologic log.

To estimate hydraulic conductivity, the modified Theis equation (Ferris and others, 1962) was first used to estimate transmissivity of the pumped interval. Transmissivity is the product of horizontal hydraulic conductivity and thickness of the hydrogeologic unit supplying water to the well.

The modified Theis equation is

$$
s=\frac{Q}{4 \pi T} \ln \frac{2.25 T t}{r^{2} S}
$$

where

$S$ is drawdown in the well, in feet;

$Q$ is discharge, or pumping rate, of the well, in cubic feet per day;

$T$ is transmissivity of the hydrogeologic unit, in square feet per day;

$t$ is length of time the well was pumped, in days;

$r$ is radius of the well, in feet; and

$S$ is storage coefficient, a dimensionless number, assumed to be 0.0001 for confined units and 0.1 for unconfined units.

Simplifying assumptions used in the derivation of equation 1 are: (1) aquifers are homogeneous, isotropic, and infinite in extent; (2) wells are fully penetrating; (3) flow to the well is horizontal; and (4) water is released from storage instantaneously. Additionally, for unconfined aquifers, drawdown is assumed to be small in relation to the saturated thickness of the aquifer. Aquifers and wells never fully meet these assumptions, and as such, the derived aquifer property values represent only approximate values. Nevertheless, for regional analysis, the magnitudes of these estimates usually prove useful.

A computer program was used to solve equation 1 for transmissivity $(T)$ using Newton's iterative method (Carnahan and others, 1969). The calculated transmissivity values were not sensitive to assumed storage coefficient values; the difference in computed transmissivity between using 0.1 and 0.0001 for the storage coefficient is a factor of about 2. Equation 2 was used to calculate horizontal hydraulic conductivity from the calculated transmissivity

$$
K_{h}=\frac{T}{b}
$$

where

$$
\begin{aligned}
& K_{h} \text { is horizontal hydraulic conductivity of the } \\
& \text { geologic material near the well opening, } \\
& \text { in feet per day; and } \\
& b \text { is thickness, in feet, approximated using the } \\
& \text { length of the open interval as reported in the } \\
& \text { driller's report. }
\end{aligned}
$$

Using the length of an open interval of a well for $b$ overestimates values of $K_{h}$ because the equations assume that all the water flows horizontally within a layer of this thickness. Although some of the flow will be outside this interval, the amount likely will be negligible because, in most aquifers, vertical flow is inhibited by geologic heterogeneity.

The resulting estimates of hydraulic conductivity using the previously described method are presented in the section, "Hydrogeologic Units". The median values of estimated hydraulic conductivities for the hydrogeologic units are similar in magnitude to values reported by Freeze and Cherry (1979, p. 29) for similar materials. These estimates are biased toward the more productive zones in these units and may not be representative of the entire unit. The minimum hydraulic conductivities estimated for the hydrogeologic units illustrate that there are zones of low hydraulic conductivity in most units in the study area. Although many uncertainties lie in the estimated values of hydraulic conductivity, these estimates provide an initial assessment of the relative differences in hydraulic conductivity between the different hydrogeologic units.

\section{Geochemistry Sampling and Analysis}

Groundwater samples for geochemical analysis were collected in upper Kittitas County primarily from domestic wells, although other well types, such as irrigation wells, also were included. Tables of the data analyzed in this report are documented in Hinkle and Ely (2013). Data used in this Scientific Investigations Report were the data available in the dynamic data report (Hinkle and Ely, 2013) as of March 7, 2013. Consistent sample collection and processing protocols were used (U.S. Geological Survey, variously dated). Groundwater samples for stable isotopes of water and tritium $\left({ }^{3} \mathrm{H}\right)$ were collected in-line (that is, not exposed to the atmosphere) from existing plumbing. Groundwater samples for other chemical and isotopic analyses were collected in-line, upgradient from pressure tanks, and upgradient from any treatment systems such as water softeners. Stream samples were collected as grab (single-point) samples from 
the centroid (center) of flow in well-mixed streams. For springs, grab samples were collected as close as possible to the spring orifice or spring discharge zone. Precipitation samples were collected as cumulative point samples designed to avoid evaporation (Friedman and others, 1992).

Samples for inorganic constituents were analyzed at the USGS National Water Quality Laboratory in Lakewood, Colorado. Trace elements in filtered water were analyzed by inductively coupled plasma-mass spectrometry and collisionreaction cell inductively coupled plasma-mass spectrometry, as described by Fishman and Friedman (1989), Garbarino (1999), and Garbarino and others (2006). Most anions were analyzed by ion chromatography (Fishman and Friedman, 1989; Fishman, 1993). Cations, silica, and minor elements were analyzed by inductively coupled plasma-atomic emission spectrometry (Fishman and Friedman, 1989; Fishman, 1993; Clesceri and others, 1998). Fluoride was analyzed by ion selective electrode (Fishman and Friedman, 1989).

Samples for major dissolved gases (dissolved nitrogen $\left[\mathrm{N}_{2}\right]$, oxygen $\left[\mathrm{O}_{2}\right]$, argon $[\mathrm{Ar}]$, methane $\left[\mathrm{CH}_{4}\right]$, and carbon dioxide $\left[\mathrm{CO}_{2}\right]$; see Glossary) were analyzed by the USGS Chlorofluorocarbon Laboratory in Reston, Virginia, by gas chromatography with flame ionization detection and gas chromatography with thermal conductivity detection (these methods are described in Busenberg and others, [1998] and U.S. Geological Survey, [2012a]). Samples for $\mathrm{SF}_{6}$ (see Glossary) were analyzed by the USGS Chlorofluorocarbon Laboratory by purge and trap gas chromatography with an electron capture detector (methods described in Busenberg and Plummer, [2000] and U.S. Geological Survey, [2012a]). Data for $\mathrm{SF}_{6}$ were scaled to the National Oceanic and Atmospheric Administration 2000 scale of atmospheric $\mathrm{SF}_{6}$ mixing ratios (National Oceanic and Atmospheric Administration, 2008). Stable isotopes of hydrogen $(\mathrm{H})$ and oxygen $(\mathrm{O})$ in water were analyzed by mass spectrometry at the USGS Reston Stable Isotope Laboratory (U.S. Geological Survey, 2013). Water samples were analyzed for stable isotopes of oxygen $\left(\delta^{18} \mathrm{O}\right)$ and stable isotopes of hydrogen $\left(\delta^{2} \mathrm{H}\right)$ by $\mathrm{CO}_{2}$ and hydrogen $\left(\mathrm{H}_{2}\right)$ equilibration, respectively (McCrea, 1950; Coplen and others, 1991); the data were normalized to the scale defined by Vienna Standard Mean Ocean Water $\left(\delta^{18} \mathrm{O}=0.00\right.$ parts per thousand [\%o], $\delta^{2} \mathrm{H}=0.0 \%$ ) and Standard Light Antarctic Precipitation $\left(\delta^{18} \mathrm{O}=-55.50 \%, \delta^{2} \mathrm{H}=-428.0 \%\right.$ ) (Gonfiantini, 1978; Coplen, 1988).

Samples for ${ }^{3} \mathrm{H}$ were analyzed by electrolytic enrichment and liquid scintillation (Thatcher and others, 1977) at the USGS Tritium Laboratory, Menlo Park, California. Samples for $\delta^{13} \mathrm{C}$ and ${ }^{14} \mathrm{C}$ were analyzed by mass spectrometry and by accelerator mass spectrometry, respectively, at the National Ocean Sciences Accelerator Mass Spectrometry Facility at the Woods Hole Oceanographic Institution in Woods Hole, Massachusetts.

\section{Seepage Investigation}

Bulk exchange of water between groundwater and surface-water systems of upper Kittitas County was characterized through a seepage run in which streamflow was synoptically measured at 41 locations on several streams over a 3-day period of stable weather between August 8 and 10, 2011 (U.S. Geological Survey, 2012b). The net volume of water gained or lost along each seepage reach was calculated as the increase or decrease in streamflow that was not accounted for by tributaries or diversions between the upstream and downstream streamflow measurement sites that bracketed each seepage reach. Streamflow was measured using the velocity-area method using standard USGS techniques with a Price AA meter or an acoustic Doppler current profiler (Oberg and others, 2005). Each streamflow measurement was assigned an accuracy rating of "good," indicating that measurements were within 5 percent margin of error; "fair," indicating that measurements were within 8 percent margin of error; or "poor," indicating that measurement error exceeds 8 percent (Sauer and Meyer, 1992). The errors in streamflow measurement at the upstream, downstream, tributary, and diversion measurement sites were propagated using the formula (Wheeler and Eddy-Miller, 2005):

$$
S=\sqrt{( \pm a)^{2}+( \pm b)^{2}+\ldots( \pm n)^{2}}
$$

where

$\mathrm{S}$ is the propagated error for the seepage gain or loss; and

$\mathrm{a}, \mathrm{b}, \ldots \mathrm{n}$ are the estimated errors for the streamflow measurements.

Seepage reaches in which the calculated seepage gain or loss was less than the magnitude of the propagated error were classified as "near-neutral." Groundwater gains and losses to a stream measured during a seepage run were aggregated over the entire extent of a seepage reach; fine-scale groundwater/ surface-water interactions may not be detected by a seepage run because of alternating gains and losses of streamflow between measurement sites or seepage rates that are lower than measurement error.

\section{Longitudinal Thermal Profiling at Ambient Stream Velocity}

Water temperature at the streambed was continuously measured at 3-second intervals while moving downstream at ambient stream velocity in a Lagrangian framework following the method of Vaccaro and Maloy (2006) for 
a 5.7-mi reach of the North Fork Teanaway River and a

3.2-mi reach of the Big Creek on September 6 and 7, 2012. Profiling in a Lagrangian framework tracks a parcel of water as it moves downstream during the day; departures from the diurnal heating cycle may be because of groundwater input, surface-water inflows, or riparian shading. Temperature was measured using a Solinst ${ }^{\circledR}$ Levelogger LT temperature probe with a reported accuracy of $\pm 0.2^{\circ} \mathrm{F}$ verified by a National Institute of Standards and Technology certified thermistor, and position data were concurrently measured using a Garmin ${ }^{\circledR}$ GPSmap ${ }^{\circledR}$ 60Csx Global Positioning System (GPS). Because low-flow conditions precluded floating downstream in a watercraft, field personnel waded downstream dragging the data-logging thermistor along the streambed. The location of each temperature measurement was determined by relating the time stamp of the GPS data to the temperature data. If a GPS location was not recorded at the same time as a temperature measurement because of a loss of GPS signal, the location of the temperature measurement was determined by linear interpolation of the two GPS locations that bracket the time of the temperature measurement.

\section{Groundwater Use Estimation}

Groundwater pumping in the Yakima River Basin was estimated as part of the USGS Yakima River Basin groundwater study for eight categories of use for 1960-2001 (Vaccaro and Sumioka, 2006). The eight categories of pumping were public water supply (including wells for Group $\mathrm{B}$, systems defined as supplies with less than 15 connections), self-supplied domestic (permit-exempt wells), irrigation, frost protection, livestock and dairy operations, industrial and commercial processes, fish and wildlife propagation, and groundwater claims. Groundwater pumpage for public supply within the study area was estimated by Ron Lane (U.S. Geological Survey, written commun., December 14, 2012). Estimates of permit-exempt (domestic) groundwater pumpage were refined for upper Kittitas County. The first step in estimating exempt well pumpage was to establish the population of self-supplied water users. This number was calculated by subtracting the public water supply population from the census block population (ig. 6). An average per capita rate was then multiplied by the self-supplied (exempt) population in each census block. For blocks in irrigation districts, a reduced per capita rate was used.

\section{Upper Kittitas County Population}

The Washington State Office of Financial Management Population Unit, a partner of the U.S. Census Bureau, develops and distributes official state and local population estimates (Washington State Office of Financial Management, 2012). These estimates are available as geographic information system (GIS) shapefiles derived from the U.S Census TIGER ${ }^{\circledR} /$ Line files. Census blocks for 2000 and 2010 were downloaded and only blocks within or touching the study area boundary were included in the final count. Census blocks are geographic subdivisions of census-block groups and are the smallest geographic area for which the Census Bureau assembles and tabulates data. When comparing block data from 2000 and 2010, it is important to note that although Census Bureau methodologies for delineating census blocks are consistent across censuses, the quantity and shape of the blocks may differ from 2000 to 2010.

\section{Public-Supply Population}

For this study, public water supply is defined as groundwater withdrawn for human consumption by public and private water systems (for example, cities, towns, rural water districts, and mobile-home parks). Public-supply systems in Washington are assigned to one of two categories: Group A or Group B. Group A systems serve at least 25 people or have at least 15 connections, and Group B systems generally are smaller and serve less than 25 people or have less than 15 connections. Group B systems were not included in the public-supply population estimate and are accounted for in the self-supplied population described in the next section.

Geographic information systems polygons delineating general areas served by some larger public water systems (Washington State Department of Health, written commun., February 13, 2012) and water system data tables were acquired from the Washington State Department of Health (2012). Additional locations and data for small publicsupply systems were downloaded from the Kittitas County Information Technology department as a point shapefile (Kittitas County, 2012). From these sources, a list of Group A systems serving the upper Kittitas County was created. The full-time residential population served by each system was totaled and compared with water-use data from the 2000 and 2010 USGS county compilations (Ron Lane, U.S. Geological Survey, written commun., December 14, 2012).

\section{Groundwater Pumpage for Industrial/Commercial Uses, Irrigation, and Public Supply Wells}

Groundwater pumpage values for Industrial/Commercial and Irrigation uses for 2000 were selected from the entire Yakima River Basin (Vaccaro and Sumioka, 2006). From the list of Group A public-supply systems created for the upper Kittitas County, groundwater pumpage amounts were taken from the 2010 USGS county compilations (Ron Lane, U.S. Geological Survey, written commun., December 14, 2012). These compilations are based on reported usage by each system on the Water Use Efficiency reports available from the Washington State Department of Health (2012). 


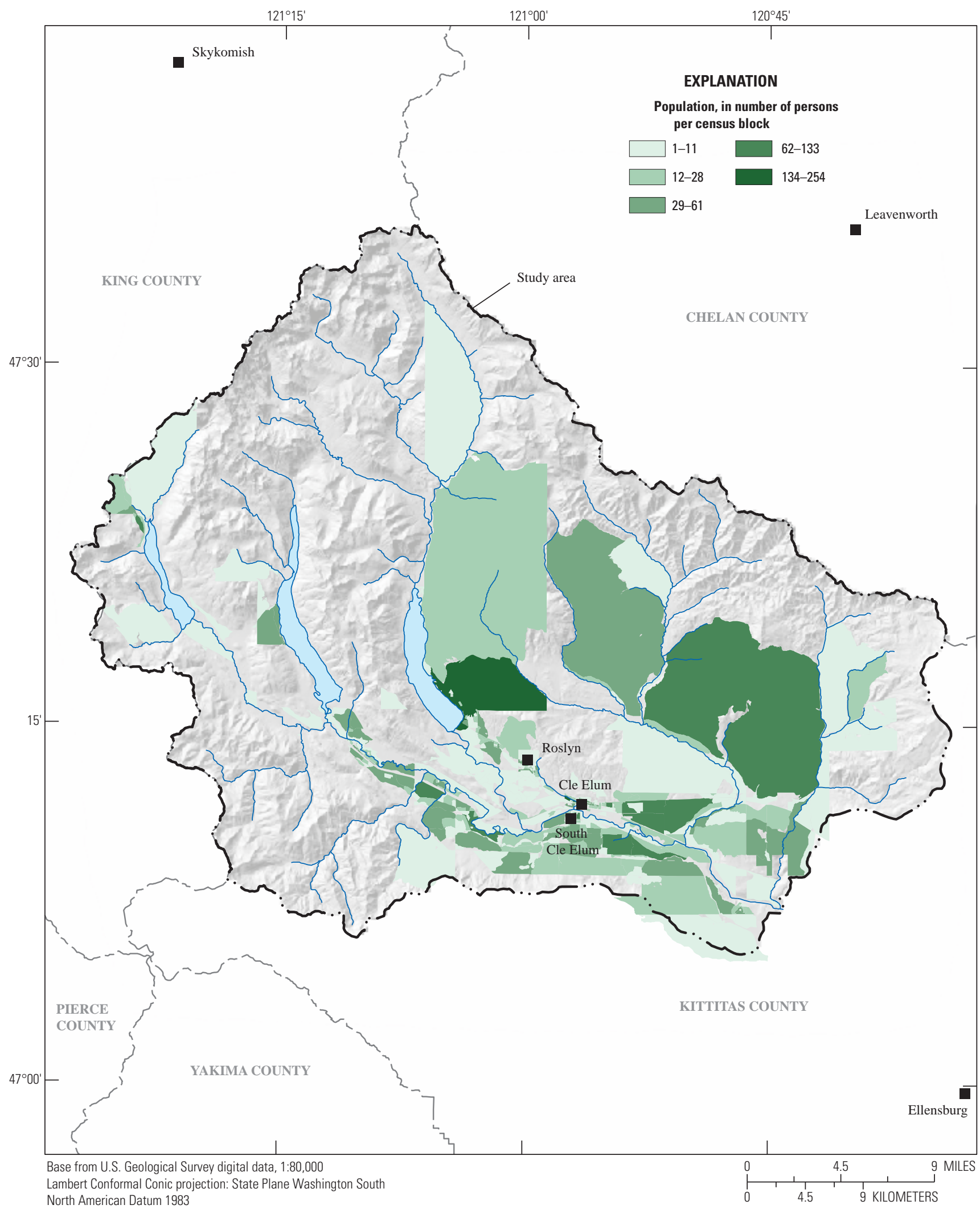

Figure 6. Distribution of population by census block for upper Yakima River Basin, Kittitas County, central Washington, during 2010 (Washington State Office of Financial Management, 2012). 


\section{Self-Supply Population}

The population of self-supplied water users was calculated by subtracting the public-supply population from the total population of the study area. For this study, selfsupplied water use refers to groundwater withdrawn for indoor and outdoor single-household use by permit-exempt wells or Group B systems using less than 5,000 gallons per day (gal/d). To estimate this population, public supply, full-time residential population-served totals for 2000 and 2010 were subtracted from the total census block populations for these respective time periods. Census blocks were assigned to likely public supply systems based on population served totals for each system, proximity to service area boundaries and Group A well locations. These census blocks were selected in the original GIS census block polygon shapefile and the remaining census blocks were an estimation of how many people are using permit exempt wells and where these populations reside.

In rural areas with low population densities, census blocks tend to be large in area. To more naturally represent the actual distribution of the population in a census block, the USGS Dasymetric Mapping Tool was used to apportion population to land-use data (Sleeter, 2008). This GIS-based tool uses population polygons, such as census blocks and some type of polygon land use or parcel data, to reapportion the population to areas where the population resides. The Washington State 2010 land use shapefile was downloaded from the Washington State Department of Ecology (2011) and used as input with 2010 census block data in the Dasymetric Mapping Tool.

\section{Groundwater Pumpage from Exempt Wells}

With the self-supplied population estimated across the study area, a per capita rate was applied to the population count to approximate pumpage from permit exempt wells. The average per capita rate of $251 \mathrm{gal} / \mathrm{d}$ for the Yakima River Basin, as determined in Vaccaro and Sumioka (2006), was used for exempt wells outside of the surface-water irrigation district. Irrigation district boundaries were used to select census blocks of self-supplied water users that were within or touching the KRD boundary. For population counts within the $\mathrm{KRD}$, the reduced average rate of $109 \mathrm{gal} / \mathrm{d}$ was used because most of the households in this district use surface water for lawn and garden watering (Vaccaro and Sumioka, 2006).

\section{Water Budget}

To construct water budgets, an existing Precipitation Runoff Modeling System (PRMS) watershed model for the Yakima River Basin developed by Mastin and Vaccaro (2002) was updated and used. The PRMS is a physical-process watershed model that calculates numerous components of the hydrologic cycle (Leavesley and others, 2005), but for the purposes of this evaluation, only precipitation, evapotranspiration, unregulated runoff, and water leaving the roots zone (recharge) are presented here. The PRMS model includes 11 subbasins (fig. 7) that cover the complete study area and was run using climate data input for water years 1950 through 2012.

\section{Hydrogeologic Framework}

Upper Kittitas County includes the eastern slope of the Cascade Range (fig. 1), which is part of the North American Cordillera. Dickinson (2004) described the geologic and tectonic evolution of the North American Cordillera, which provides a regional context for the geology of the study area. Several recent (2000s) geologic maps of central-eastern Washington, including Dragovich and others (2002), Brown and Dragovich (2003), Cheney and Hayman (2007), and Haugerud and Tabor (2009) detail the geology of upper Kittitas County. Haugerud and Tabor's (2009) geologic map of the North Cascade Range contains descriptions of the tectonic evolution and map units in the area. A geologic map of the study area was clipped from a larger map by Haugerud and Tabor (2009) and is included on plate 1, along with project well and spring locations. A summary of the geologic units in the study area is shown on plate 1 ; the regional geologic setting of the study area modified from Tabor and others (2000) is shown in figure 8.

Haugerud and Tabor (2009) divided the complex geology of upper Kittitas County into five major groups; from oldest to youngest, these groups include: (1) orogenic (mountain building) and pre-orogenic rocks, (2) rocks of late- and post-orogenic transtension, (3) rocks of Cascade magmatic arc, (4) flood basalts and associated deposits, and (5) unconsolidated deposits.

\section{Orogenic and Pre-Orogenic Rocks}

During the Triassic Period, approximately 200 million years ago, the North American plate moved westward, subducting the oceanic lithosphere of the Pacific Ocean eastward, beneath North America. During subduction, the western edge of the continent grew westward as terranes of exotic volcanic islands and ocean-floor rocks were accreted and subsequently welded by continental arc plutonism and volcanism. The oldest rocks in upper Kittitas County, which record subduction along the western margin of the Pacific Northwest, are those of the Jurassic Ingalls terrane mapped by Haugerud and Tabor (2009) as units Jis, Jbi, and Jbs, and are located at the northern edge of the county boundary, east of the Straight Creek Fault (SCF) (pl. 1). These rocks are predominantly ultramafic rocks, with unit Jis including lherzolite, harzburgite, and serpentinite; unit Jbi including resistant igneous and meta-igneous rocks; and Jbs including resistant sedimentary rocks. 


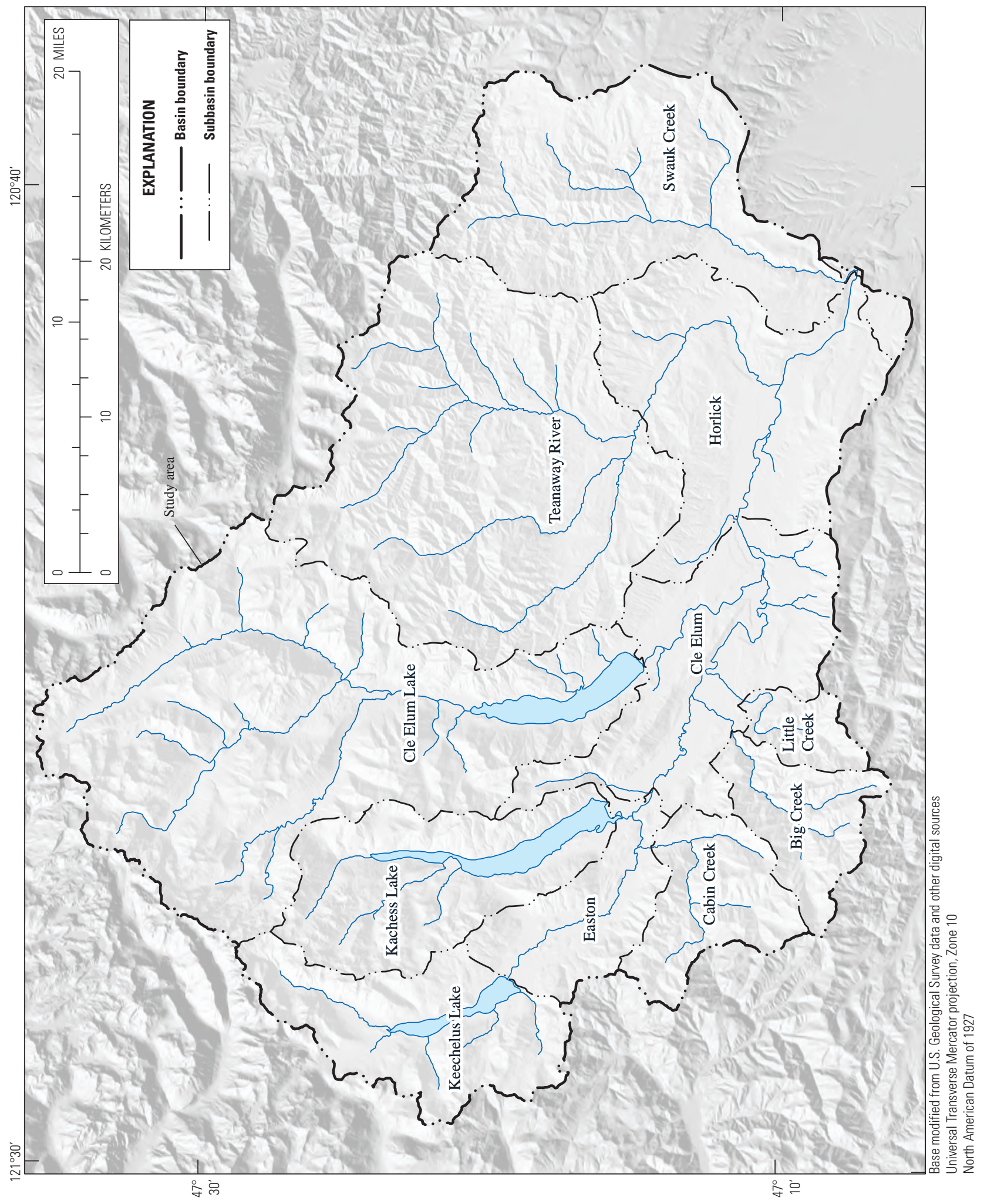

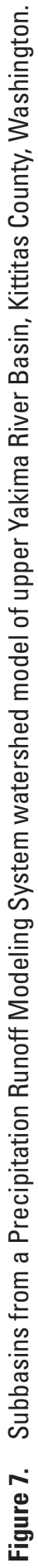




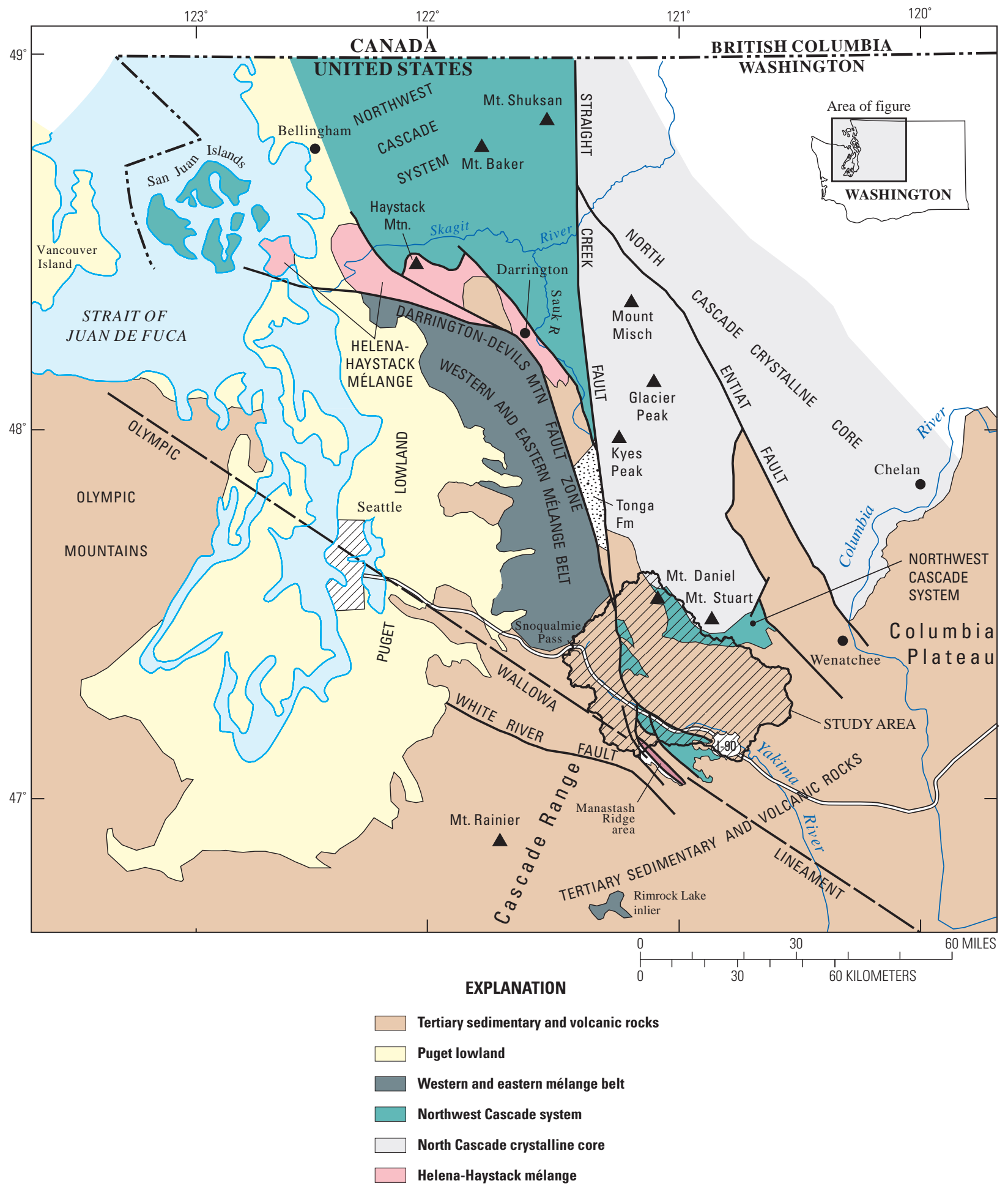

Figure 8. Regional geologic setting of the upper Yakima River Basin, Kittitas County, Washington. Modified from Tabor and others (2000). 
The Easton terrane includes the tonalite gneiss of Hicks Butte, Darrington Phyllite, and Shuksan Greenschist (units Ket, Ked, and Kes, respectively; Haugerud and Tabor, 2009; pl. 1). Shuksan Greenschist is a fine-grained but wellrecrystallized metamorphic rock, formed as ocean-floor basalt in the Middle and Late Jurassic and metamorphosed in the Early Cretaceous (Brown, 1986). This was overlain by oceanic shale and sandstone that metamorphosed to the Darrington Phyllite, which consists mostly of well-recrystallized, finegrained, graphitic quartz-albite-muscovite schist, with secondary foliation (Haugerud and Tabor, 2009).

\section{Late- and Post-Orogenic Transtension}

From Late Cretaceous to earliest Oligocene time, the North Cascades deformed transtensionally (a process that included strike-slip motion with a component of extension). This deformation occurred along the SCF (Tabor, 1994), the Darrington-Devils Mountain Fault Zone (DDMFZ), and through extensional subsidence of the local depositional basins that span much of upper Kittitas County (Tabor and others, 2000; fig. 8). The SCF is a high-angle, right-lateral strike-slip fault that begins north of the United States-Canada border and runs south, bisecting the DDMFZ before crossing western upper Kittitas County, where it generally maintains a north-south orientation (igg. 8). The SCF terminates just south of the upper Kittitas County study area, at the northwestsoutheast trending Olympic-Wallowa Lineament (fig. 8). The DDMFZ is a high-angle, north-side-up thrust fault with a dominant component of left-lateral slip. The DDMFZ is north of upper Kittitas County in the Northwest Cascade System, Western and Eastern Mélange Belt, and Helena-Haystack Mélange (Haugerud and Tabor, 2009), and extends south into west-central upper Kittitas County, with an approximately northwest-southeast orientation (fig. 8; pl. 1).

Faulting, subsidence, and deposition are evidenced by rocks of late- and post-orogenic transtension (Haugerud and Tabor, 2009), mostly superimposed on Cretaceous metamorphism and deformation. In upper Kittitas County, early extensional deposits (unit Tees, pl. 1) are mostly thick bedded fluvial feldspathic siltstone, sandstone and conglomerate of the Swauk Formation, deposited by streams in fault-bounded basins or regional synclines. In places, the sedimentary rocks of the Swauk Formation are interbedded and overlain by dacite and andesite flows, breccia, and tuff of its early Eocene Silver Pass Volcanic Member (unit Teev, pl. 1). The relatively undeformed middle Eocene Teanaway Formation of andesite and basalt flows, tuff, and breccia with minor rhyolite unconformably overlies the Swauk Formation (Tabor and others, 2000; unit Tev, pl. 1). The fluvial middle and late Eocene Roslyn Formation conformably overlies the Teanaway and is composed of feldspathic sandstone, is conglomerate rich in its lowermost part, and contains extensively mined coal beds in the uppermost of its three subunits (Tabor and others, 2000; unit Tes, pl. 1).

\section{Cascade Magmatic Arc}

Rocks of the Cascade Magmatic Arc are both intrusive and volcanic. In the study area, the intrusive rocks of the arc are those of the Miocene and Oligocene Snoqualmie family, mostly tonalite, granodiorite, and gabbro (unit Tcas; Haugerud and Tabor, 2009; pl. 1); the volcanic rocks in the study area include volcanic and sedimentary rocks of the Oligocene Ohanapecosh episode and volcanic rocks of the Miocene Fifes Peak Episode (units Tcao and Tcaf, respectively; Haugerud and Tabor, 2009; pl. 1). Rocks from both eruptive episodes are mostly basalt, andesite, and rhyolite; breccia and tuff occur locally.

\section{Flood Basalts and Associated Deposits}

Rocks of the Miocene Columbia River Basalt Group (CRBG) include flood basalts and associated sedimentary interbeds (Swanson and others, 1979; Drost and others, 1990). The CRBG consists of a series of flows erupted during various stages of the Miocene Age, 17-6 million years ago. The basalt lava flowed from fissures and vents in eastern Washington, northeastern Oregon, and western Idaho, covering more than $50,000 \mathrm{mi}^{2}$. More than 300 flows have been identified, and individual flows range in thickness from 10 to more than $300 \mathrm{ft}$ (Tolan and others, 1989; Drost and others, 1990). Typically, lava erupted quickly and advanced away from the fissure or vent as a single, uniform sheet of lava. When the hiatus between flows was sufficiently long, soil developed or sediments were deposited on the surface of a flow. If these sediments were preserved, a sedimentary interbed occurred between flows. Although there are four flood basalt groups (formations), each with individual basalt flows, the only one in southeastern upper Kittitas County is the Grande Ronde basalt (Reidel and others, 1989) (Haugerud and Tabor, 2009; unit Tyg, pl. 1). Upper Kittitas County is in the westernmost reaches of the flood basalts and, as such, is a transitional area between the basalt-filled Columbia Plateau and the Cascade Mountain physiographic province. The Grande Ronde Basalt is "typically composed of fine-grained, aphyric, tholeiitic basalt” (Reidel and others, 1989, p. 22).

\section{Unconsolidated Deposits}

The youngest materials in the study area are unconsolidated deposits that include both glacial and nonglacial sediment. Glacial deposits consist of those left by southeast flowing alpine glaciers that entered lower valleys about 22,000-18,000 years ago (Haugerud and Tabor, 2009; Porter, 1976; unit Qag, pl. 1) during the Fraser glaciation. These deposits, or drift, commonly contain "till, erratic stones, outwash, glacial-lacustrine sediment, and ice-contact stratified drift" (Porter, 1976, p. 62). Nonglacial deposits include landslide deposits (Haugerud and Tabor, 2009; 
unit Qtl, pl. 1) of the Holocene, Pliocene, and Pleistocene, the greatest of which are along the edge of the CRBG in upper Kittitas County. Holocene and Pleistocene alluvium consists of moderately- to well-sorted river deposits and lacustrine deposits on major valley bottoms (Haugerud and Tabor, 2009; unit Qa, pl. 1), and an assortment of undifferentiated deposits (Haugerud and Tabor, 2009; unit Qu, pl. 1), including alluvium, colluvium, soil, alluvial fans, and some landslide debris (pl. 1). Other nonglacial deposits include unsorted talus (Haugerud and Tabor, 2009; unit Qt, pl. 1).

\section{Hydrogeologic Units}

The unconsolidated sediment unit occurs at land surface over about 27 percent $\left(229.4 \mathrm{mi}^{2}\right)$ of the study area. It is composed of unconsolidated glacial and non-glacial deposits, including alluvium, talus, landslide deposits, alpine glacial deposits, recessional outwash, and outburst flood deposits; at depth, the unit also includes thick glaciolacustrine deposits beneath the broad valley floors. Sixty-seven of the project wells are open to the unconsolidated sediment unit (table 2). Reported yields for 53 project wells open to this unit range from $0 \mathrm{gal} / \mathrm{min}$ (dry well) to $1,600 \mathrm{gal} / \mathrm{min}$, with a median reported yield of $25 \mathrm{gal} / \mathrm{min}$ (table 2). Based on data from 10 inventoried wells completed in this unit, the estimated horizontal hydraulic conductivity ranges from 4.4 to 1,600 feet per day (ft/d), with a median hydraulic conductivity of $190 \mathrm{ft} / \mathrm{d}$ (table 2).

The total thickness of the unconsolidated unit is greatest, reaching more than $600 \mathrm{ft}$, along the valley floors where large amounts of sediment have accumulated. In a detailed analysis of the sedimentary deposits in the Roslyn Basin, Jones and others (2006) reported three subunits that make up the unconsolidated sediment unit described in this report. Jones and others (2006) described these as an upper coarse-grained (gravel and sand) aquifer with a median thickness of $80 \mathrm{ft}$, a middle fine-grained (silt and clay) and low productivity unit with a median thickness of $170 \mathrm{ft}$, and a lower coarse-grained (gravel) aquifer with a median thickness of $50 \mathrm{ft}$. These subunits occur at depth beneath the broad valley floors down valley from Kachess and Cle Elum Lakes toward the southeast end of the study area near Teanaway.

The basalt unit occurs at land surface over about 3 percent $\left(24.6 \mathrm{mi}^{2}\right)$ of the study area and includes the Grande Ronde basalt unit and associated interbeds of the Ellensburg Formation. Conceptually, the basalt unit is a series of productive interflow zones separated by less permeable flow interiors and interlayered in places with sedimentary material (Kahle and others, 2011). This unit occurs only in the southeast part of the study area where the basalt overlies the older sedimentary unit (section $\mathrm{C}-\mathrm{C}^{\prime}, \mathrm{pl} .2$ ). Only nine of the project wells are open to the basalt unit (table 2; pl. 2). Reported yields for eight project wells open to the basalt unit range from 1 to $75 \mathrm{gal} / \mathrm{min}$, with a median yield of $17.5 \mathrm{gal} / \mathrm{min}$ (table 2). Although none of the project wells completed in the basalt unit had sufficient data to estimate horizontal hydraulic conductivity, Kahle and others (2011) reported a value of $70 \mathrm{ft} / \mathrm{d}$ based on records from 573 wells completed in the Columbia River basalts across the broader Columbia Plateau.

The volcanic unit occurs at land surface over about 27 percent $\left(231.3 \mathrm{mi}^{2}\right.$ ) of the study area, including most of the highlands west of Cle Elum Lake and in a band in the central part of the study area that includes Teanaway Ridge (pl. 2). The unit is composed largely of basalt and rhyolite flows, breccia, and tuff intermixed with some sandstone and conglomerate of the Teanaway Formation (Tev unit, pl. 1), with lesser amounts of basalt, andesite, some rhyolite, breccias, and tuffs of the Fifes Peak episode (Tcaf unit, pl. 1) and Ohanapecosh episode (Tcao unit, pl. 1). This unit also includes dacite and andesite flows and pyroclastic rocks of the Silver Pass Volcanic Member of the Swauk Formation located between Kachess and Cle Elum Lakes (Teev unit, pl. 1). Eighteen of the project wells are open to the volcanic unit (table 2, pl. 2). Reported yields for 14 project wells open to the volcanic unit range from 3 to $42 \mathrm{gal} / \mathrm{min}$, with a median yield of $18 \mathrm{gal} / \mathrm{min}$ (table 2). The estimated horizontal hydraulic conductivity for well 21N/12E-22A01 (the only well in the volcanic unit with complete yield data) is $0.02 \mathrm{ft} / \mathrm{d}$ (tables 2 and 7 ).

The sedimentary unit occurs at land surface over about 34 percent $\left(290.9 \mathrm{mi}^{2}\right)$ of the study area, including most of the northeastern part of the study area (pl. 2). The unit includes sandstone and conglomerate with subordinate shale and coal of the Roslyn Formation (Tes unit, pl. 1) and stream-deposited sandstone and conglomerate of the Swauk Formation (Tees unit, pl. 1). One hundred thirteen of the project wells are open to the sedimentary unit (table 2; pl. 2). Reported yields for 94 of the project wells open to the sedimentary unit range from 0 (dry well) to $150 \mathrm{gal} / \mathrm{min}$, with a median reported yield of $10 \mathrm{gal} / \mathrm{min}$ (table 2). Two wells completed in the sedimentary unit, 21N/14E-28R01 and 21N/17E-22N01, have estimated horizontal hydraulic conductivity values of 1.6 and $3.6 \mathrm{ft} / \mathrm{d}$, respectively (tables 2 and $\mathbf{7}$ ).

The metamorphic unit occurs at land surface over about 4 percent $\left(38.4 \mathrm{mi}^{2}\right)$ of the study area in a northwest trending band in the west central part of the study area (pl. 2). The metamorphic unit includes black phyllite (typically with abundant quartz veinlets) of the Darrington Phyllite (Ked unit, pl. 1) and fine grained greenschist and (or) blueschist derived mostly from ocean-floor basalt of the Shuksan Greenschist (Kes unit, pl. 1). Twenty of the project wells are open to the metamorphic unit (table 2; pl. 2). Reported yields for 17 of the project wells open to the metamorphic unit range from 0 (dry well) to $40 \mathrm{gal} / \mathrm{min}$, with a median reported yield of $3 \mathrm{gal} / \mathrm{min}$ (table 2). None of the project wells completed in the metamorphic unit had complete well yield data with which to estimate hydraulic conductivity. Freeze and Cherry (1979) report hydraulic conductivities of between about $1.3 \times 10^{-4} \mathrm{ft} / \mathrm{d}$ and $1.3 \times 10^{-8} \mathrm{ft} / \mathrm{d}$ for unfractured metamorphic rocks. However, values may be somewhat larger in fractured metamorphic rocks. 
The intrusive unit occurs at land surface over about 5 percent $\left(45.4 \mathrm{mi}^{2}\right)$ of the study area, mostly in the Wenatchee Mountains and in limited occurrences along the westernmost margin (pl. 2). The intrusive unit includes peridotite and foliated and massive serpentinite of the Ingalls terrane (Jis unit, pl. 1). Only three of the project wells are open to the intrusive unit (table 2, pl. 2). Reported yields for the three project wells open to the intrusive unit range from 0 (dry well) to $60 \mathrm{gal} / \mathrm{min}$, with a median reported yield of $5 \mathrm{gal} / \mathrm{min}$ (table 2). None of the project wells completed in the intrusive unit had complete well yield data with which to estimate hydraulic conductivity. Freeze and Cherry (1979) report hydraulic conductivities of between about $1.3 \times 10^{-4} \mathrm{ft} / \mathrm{d}$ and $1.3 \times 10^{-8} \mathrm{ft} / \mathrm{d}$ for unfractured igneous rocks. As with the metamorphic unit, hydraulic conductivity values in the intrusive unit would vary depending on the degree and location of fractures.

A summary of well yields, as reported on drillers' logs used during this investigation, is shown in table 2 by hydrogeologic unit. Well-yield testing is done to determine if an adequate and sustainable yield is available from a well. Driller-reported well yields are not only dependent on the productivity of the unit to which the well is open, but also are a function of the design and purpose of the well. During well-yield testing, a well that was intended for municipal purposes likely would be pumped at a higher rate and have a larger diameter casing and a longer open interval than a well that was intended for single-family use, thereby having an apparent higher yield than that for the single-family well. Despite the fact that yields often are estimates, they are useful in comparing the general productivity of hydrogeologic units and illustrate variability within a single unit. The median well yields of the unconsolidated sediment unit, the basalt unit, the volcanic rock unit, and the sedimentary rock unit are 25 , $17.5,18$, and 10 gallons per minute (gal/min), respectively. These values are greater than those for the metamorphic and intrusive units that have median yields of 3 and $5 \mathrm{gal} / \mathrm{min}$, respectively. Yields in these dense crystalline units are highly dependent on secondary fracture permeability through which groundwater may move.

\section{Geochemistry}

Water samples collected from wells and springs, samples from small streams, and samples of atmospheric precipitation were collected between 2010 and 2012 for geochemical and isotopic constituents (fig. 9).

Chemical constituents included selected dissolved gases and a suite of inorganic elements and compounds that are commonly present in natural waters. Natural waters contain dissolved gases and inorganic constituents as a result of interactions with gases, fluids, soils, and rocks. Dissolved $\mathrm{SF}_{6}$ contributes to the understanding of groundwater residence time (“age dating”; see Glossary). Dissolved $\mathrm{N}_{2}$ and $\mathrm{Ar}$ are used to characterize recharge conditions (for example, recharge temperature) used to interpret $\mathrm{SF}_{6}$ data. Inorganic constituents include the dominant rock-forming elements commonly detected in groundwater (for example, calcium and sodium) as well as other naturally occurring constituents that typically are detected in groundwater at trace concentrations (for example, arsenic and vanadium) (Hem, 1985). The inorganic chemistry of groundwater constitutes a record of the interaction of groundwater with the soils and rocks through which the groundwater has passed - a record that also reflects the amount of time that groundwater has resided in different parts of the hydrogeologic system.

Isotopes are atoms of an element distinguished by having different numbers of neutrons. Isotopes are either stable or radioactive (decaying or changing from one isotope to another over time). The isotopes of interest in this report include:

- Stable isotopes of water (oxygen-16 $\left[{ }^{16} \mathrm{O}\right]$ and ${ }^{18} \mathrm{O}$, expressed as $\delta^{18} \mathrm{O}$, and ${ }^{1} \mathrm{H}$ and ${ }^{2} \mathrm{H}$, expressed as $\delta^{2} \mathrm{H}$ );

- Tritium (radioactive ${ }^{3} \mathrm{H}$ ) in water;

- Stable isotopes of carbon $\left({ }^{12} \mathrm{C}\right.$ and ${ }^{13} \mathrm{C}$, expressed as $\delta^{13} \mathrm{C}$ ) of dissolved inorganic carbon (DIC); and

- The common radioactive isotope of carbon, ${ }^{14} \mathrm{C}$ (expressed as percent modern carbon, or PMC) in DIC.

As water moves through atmospheric and surface compartments, the ratios of the stable isotopes of water can change, imparting distinct isotopic signatures to water in some of those compartments. In contrast, the stable-isotope composition of most groundwater below the vicinity of the water table does not change except under elevated temperature conditions or unusual settings such as some deep-basin brines (Clark and Fritz, 1997). Thus, groundwater provenance can sometimes be identified on the basis of the stable isotopic composition of the groundwater. Tritium is another common isotope of water that serves a different purpose in groundwater studies. Water recharging aquifers contains ${ }^{3} \mathrm{H}$ produced in the atmosphere. Time elapses as groundwater moves along flow paths in aquifers, and as time passes, ${ }^{3} \mathrm{H}$ decays to helium-3 ( $\left.{ }^{3} \mathrm{He}\right)$. Thus, ${ }^{3} \mathrm{H}$ can be used to characterize general timeframes of groundwater age. Finally, because groundwater contains DIC, radioactive decay of ${ }^{14} \mathrm{C}$ in DIC allows hydrologists to place constraints on groundwater age.

\section{Stable Isotopes of Water}

Stable isotopes of water were used to characterize the origin of water collected from different parts of the groundwater system. Stable isotope data for samples from wells, springs, small streams, and precipitation in the upper Kittitas County study area are shown in figure 10. Most of these data, collected in central Washington, are near the local meteoric water line derived by Kendall and Coplen (2001) for western Washington and Oregon $\left(\delta^{2} \mathrm{H}=8.20 \cdot \delta^{18} \mathrm{O}+12.39\right)$. 


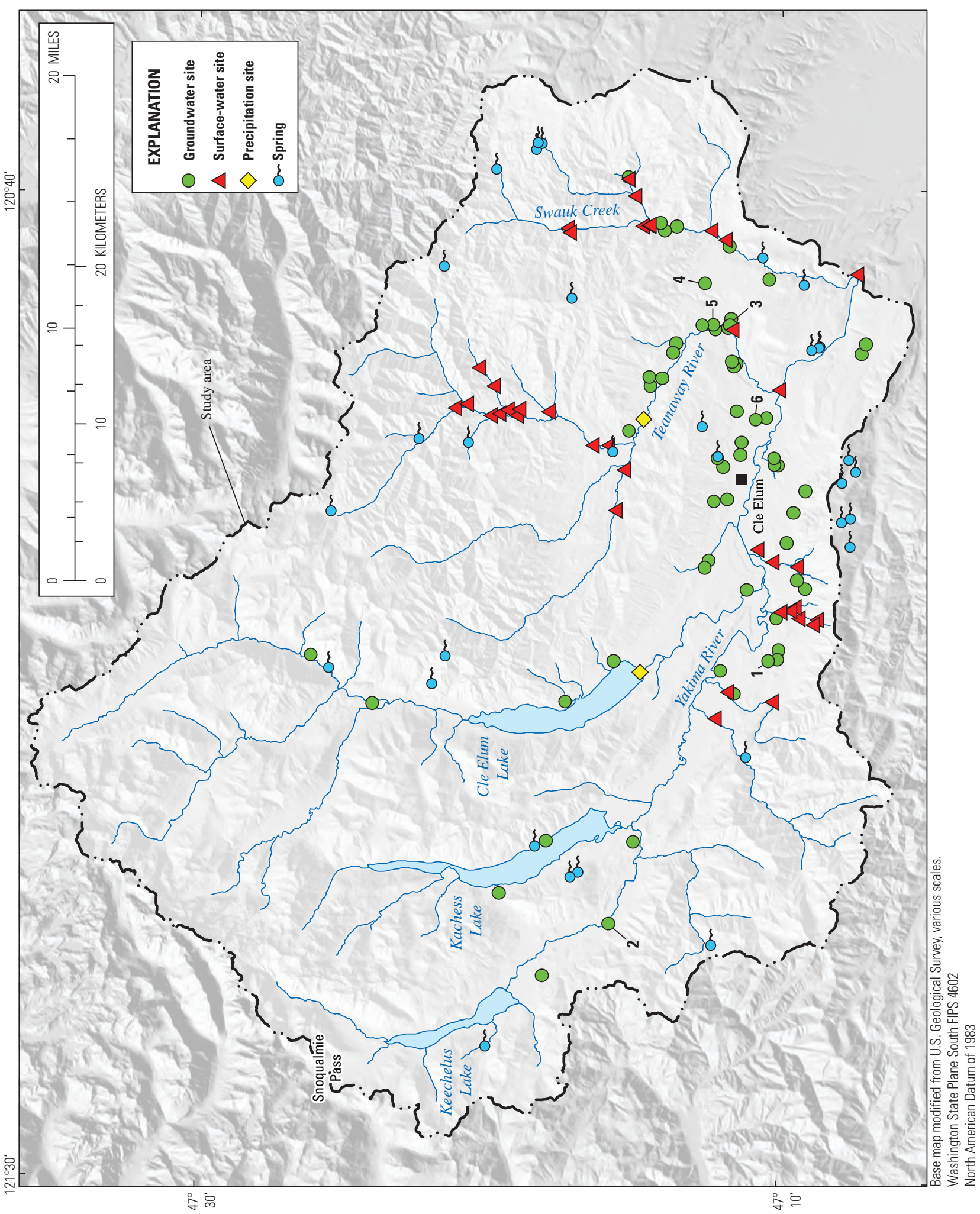

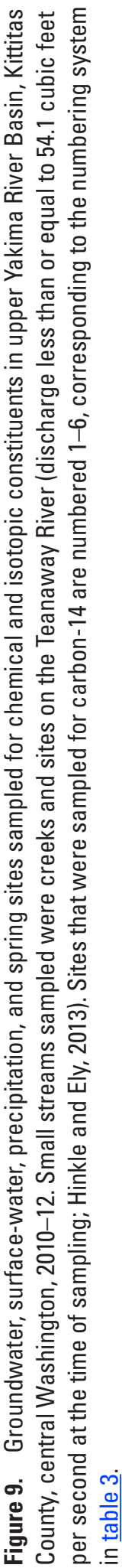




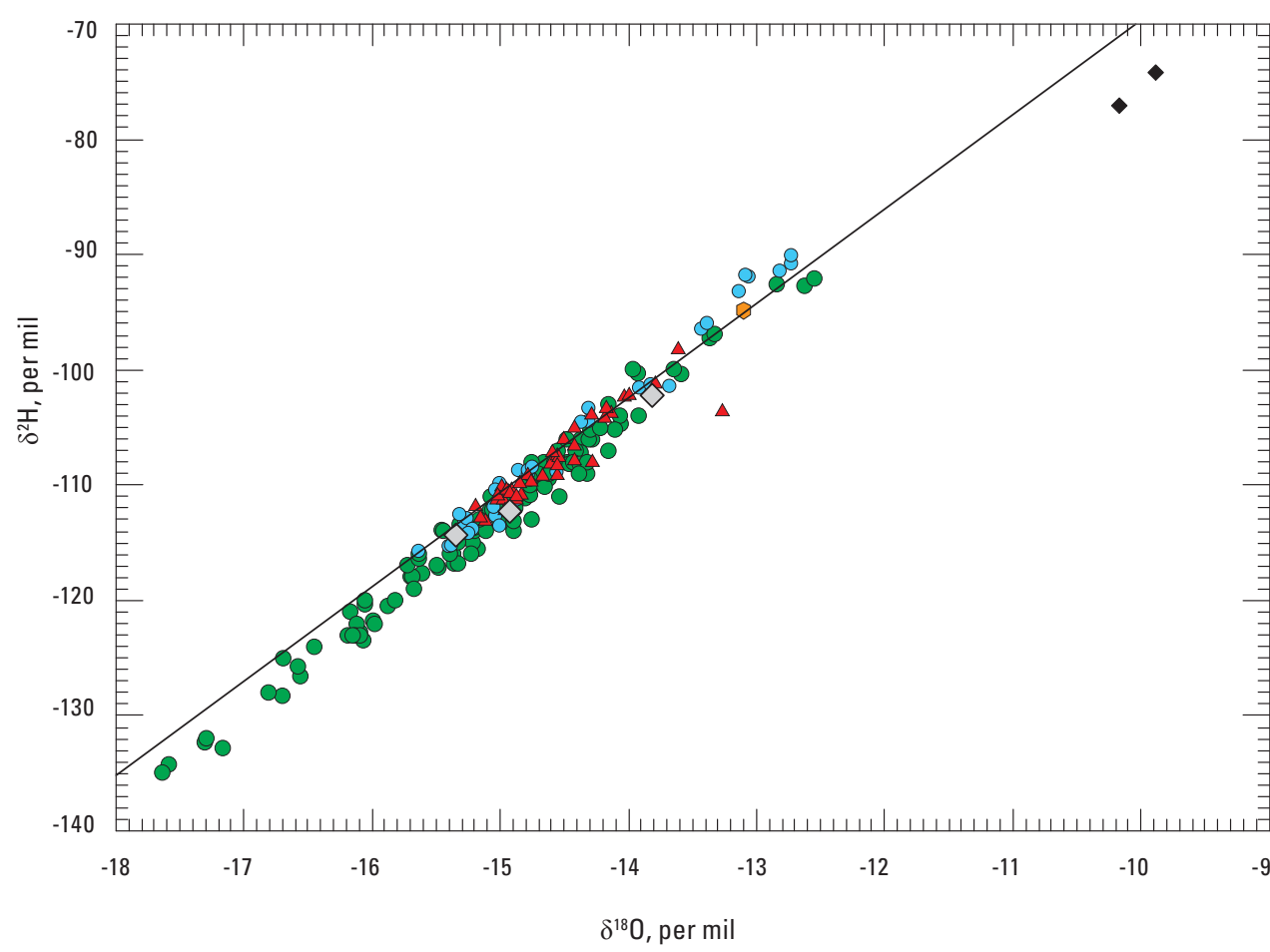

EXPLANATION

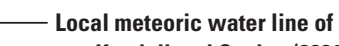

Kendall and Coplen (2001)

- Wells

$\bigcirc$ Springs

$\Delta$ Small streams

- Precipitation (summer)

$\diamond$ Precipitation (winter)

- Yakima River at Cle Elum

(mean of 43 samples; Vaccaro, 2011)

Figure 10. Stable isotope (hydrogen, $\delta^{2} \mathrm{H}$; oxygen, $\delta^{18} \mathrm{O}$ ) data for wells, springs, small streams, and precipitation samples from upper Yakima River Basin, Kittitas County, central Washington, 2010-12. Precipitation samples were integrated, long-term samples (Hinkle and Ely, 2013). Small streams sampled were creeks and sites on the Teanaway River (discharge less than or equal to 54.1 cubic feet per second at the time of sampling; Hinkle and Ely, 2013). Data for the Yakima River at Cle Elum are shown as a point representing the mean of 43 temporal samples from 1987 to 1991 (Vaccaro, 2011).

One of the small-stream samples (the farthest-to-the-right, small-stream $\delta^{18} \mathrm{O}$ value in figure 10) appears to be an outlier. This small-stream sample, collected from Lick Creek when flowing at only $0.02 \mathrm{ft}^{3} / \mathrm{s}$, apparently was evaporated, thus enriching its stable isotope content (that is, preferentially increasing the heavy isotope). This sample was excluded from further analysis. The two "summer" precipitation samples (samples near the upper right corner of figure 10) also may have been affected by evaporation-in this case, likely from raindrop surfaces during rainfall in the low-precipitation season (Clark and Fritz, 1997, p. 51). These precipitation samples are similar to summer $\delta^{18} \mathrm{O}$ values reported by Robertson and Gazis (2006) for nearby precipitation measured at Cle Elum (range: -8.0 to $-10.1 \%$ ), and likely are representative of typical summer precipitation at the collection sites. The near linearity of the $\delta^{2} \mathrm{H}$ and $\delta^{18} \mathrm{O}$ data allows further analysis and discussion of stable isotopes of water to focus on $\delta^{18} \mathrm{O}$ data $\left(\delta^{18} \mathrm{O}\right.$ analysis having greater precision than analysis of $\delta^{2} \mathrm{H}$ ).

The isotopic character of water samples provides information about their origin. Water samples from wells exhibit a wide range in $\delta^{18} \mathrm{O}$ values: -12.55 to $-17.64 \%$. This large range reflects various source areas at different locations and possibly different climatic regimes at the time of recharge.
Water samples collected from springs display a narrower range in $\delta^{18} \mathrm{O}$ values: -12.73 to $-15.64 \%$. This suggests that the part of the flow system discharging to the sampled springs may be different from the part of the flow system tapped by the sampled wells.

Samples from small streams span an even smaller range in $\delta^{18} \mathrm{O}$ values: -13.61 to $-15.19 \%$ (excluding Lick Creek). However, these small streams do not include the large rivers (Yakima and Cle Elum Rivers) in the study area that capture western provenance, high-elevation precipitation from near the crest of the Cascade Mountains. Rather, the small streams were creeks plus sites on the Teanaway River that had discharge of less than or equal to $54.1 \mathrm{ft}^{3} / \mathrm{s}$ at the time of sampling, and were located primarily in the eastern half of the upper Kittitas County study area (fig. 9). Stream water typically is a composite or synthesis of multiple surface and subsurface (including groundwater) sources; therefore, the isotopic composition of stream water tends to have a value that represents a weighted average of the various individual sources contributing to streamflow (Buttle, 1998). The relatively small range in stream water $\delta^{18} \mathrm{O}$ values, compared to the ranges from water samples collected from wells and springs, likely reflects this integrating effect, but also reflects the geographically limited extent of the sampling sites. The 
effect of expanding the geographical extent is demonstrated by consideration of the $\delta^{18} \mathrm{O}$ character of the Yakima River at Cle Elum (downstream of the confluence of the Cle Elum River with the Yakima River; fig. 2). The mean $\delta^{18} \mathrm{O}$ value of 43 samples collected at this site between 1987 and 1991 was $13.10 \%$ (fig. 10; Vaccaro, 2011), and represents highelevation, western source areas. Inclusion of these data lead to a broader range in surface-water $\delta^{18} \mathrm{O}$ values $(-13.10$ to $-15.19 \%$ ) similar to the range in groundwater-spring $\delta^{18} \mathrm{O}$ values (-12.73 to $-15.64 \%$ ) (fig. 10).

Five samples of precipitation, collected as composite samples each representing about 6 months of precipitation, were collected near the Cle Elum River (near the Roslyn Dam at the southeastern edge of Cle Elum Lake; fig. 2) and the Teanaway River (below the confluence of the West, Middle and North Forks; fig. 2). "Winter" $\delta^{18} \mathrm{O}$ samples (September 17, 2010-March 24, 2011; aggregated snow and rain from the Cle Elum River site, separate snow and rain samples from the Teanaway River site) were $-13.82 \%$ at the Cle Elum site and -14.92 (rain) to $-15.34 \%$ (snow) at the Teanaway site, whereas "summer" samples (March 24, 2011-October 25, 2011) were close to $-10 \%$. These precipitation samples, which were collected from a small cross section of the study area, are not representative of the full range of precipitation across the study area. For example, Hammond (2009) reported 6-month-average snowmelt $\delta^{18} \mathrm{O}$ of $-13.1 \%$ at Snoqualmie Pass (western edge of the study area)—precipitation that is isotopically heavier than the more easterly (Cle Elum Lake and Teanaway River) samples shown in figure 10 for "winter" precipitation.

Groundwater and surface-water samples shown in figure 10 originated as precipitation that fell at some time prior to sample collection. These groundwater and surface water samples represent a combination of primarily autumn-winterspring precipitation, along with small amounts of summer precipitation. Isotopically light groundwater $\left(\delta^{18} \mathrm{O}\right.$ more negative than about $-16 \%$ ) present in some samples collected from wells is distinct from the remaining, isotopically heavier groundwater, as well as the surface-water and precipitation samples, and will be analyzed and discussed in more detail.

\section{Temporal Patterns of Delta-0xygen-18}

Stable isotope samples from selected wells were collected at various temporal scales (timescales of well purging and seasonal timescales) to determine the degree to which the range in $\delta^{18} \mathrm{O}$ values reported for samples collected from wells for stable isotopes of water reflect temporal changes in water withdrawn from wells. Six sets of replicate samples (five sets of triplicates and one set of quadruplicates) were collected at periodic intervals over the course of well purging to assess variability during well pumping. Standard deviations for $\delta^{18} \mathrm{O}$ values range from 0.03 to $0.18 \%$, with the greatest variability in samples from a well (20N/16E-24G01) in sandstone (a hard sedimentary rock; 0.18\%o) and a well (19N/14E-02C01) in phyllite (a metamorphic rock; $0.13 \%$; data for this well plotted in fig. 11A). The standard deviations in samples from these two wells are greater than the laboratory standard deviation of $0.10 \%$, possibly reflecting variations in the sources of groundwater to wells over the course of pumping.

Temporal variability at the timescale of seasons also is evident in $\delta^{18} \mathrm{O}$ data collected from wells at seasonal timescales. One set of seasonal samples was collected from well 19N/14E-02C01. The temporal data for this well are plotted in figure 11B. The standard deviation for these seasonal samples is $0.24 \%$, greater than the standard deviation observed over the course of well pumping $(0.13 \%)$.

Seasonal variability also can be assessed by calculating the absolute difference in $\delta^{18} \mathrm{O}$ values for samples from 42 wells collected during spring (March-April) 2011 and late summer (August) 2011. Mean absolute differences were $0.04 \%$ for unconsolidated sediments, $0.07 \%$ for flood basalts and other volcanic rocks, and $0.19 \%$ for sedimentary and metamorphic rocks.

These examples exhibit greater variability in $\delta^{18} \mathrm{O}$ values at sites withdrawing groundwater from sedimentary and metamorphic rocks and provide insights into the nature of groundwater flow in the study area. Metamorphic rocks in the study area typically transmit water almost entirely through fractures (Vaccaro and others, 2009). Groundwater moves through pores and fractures in sedimentary rocks (Neuman, 2005), but well yields from sedimentary rocks in the study area typically are low (Vaccaro and others, 2009). Groundwater flow in these sedimentary rocks probably is controlled primarily by fracture flow in most cases. The temporal variability in $\delta^{18} \mathrm{O}$ values in water from some of the wells in metamorphic and sedimentary rocks is consistent with the understanding that groundwater flow in fractured media is controlled by discrete fractures (Neuman, 2005), some of which may be quickly dewatered when stressed (Driscoll, 1986). To the degree that different fractures contain water with slightly different isotopic character, temporally variable contributions from different fractures to a well will lead to temporally variable isotopic character of pumped water. Such temporal variations will tend to be less pronounced in sand and gravel aquifers, owing to efficient dispersion in such poredominated flow systems.

Temporal variability was observed in $\delta^{18} \mathrm{O}$ values of groundwater samples collected from wells. The magnitude of this temporal variability was smallest for unconsolidated sediment, and greatest for fractured sedimentary and metamorphic rock aquifers. These differences in temporal variability are consistent with the nature of groundwater flow in pore-dominated compared with fracture-dominated systems, and consistent with the presence of complex groundwater flow dynamics in parts of the fractured sedimentary and metamorphic rock aquifer units in the study area. However, the magnitude of this temporal variability is small compared to the environmental variability across the study area (for example, fig. 10). This allows for the analysis of spatial patterns in groundwater $\delta^{18} \mathrm{O}$ data. 

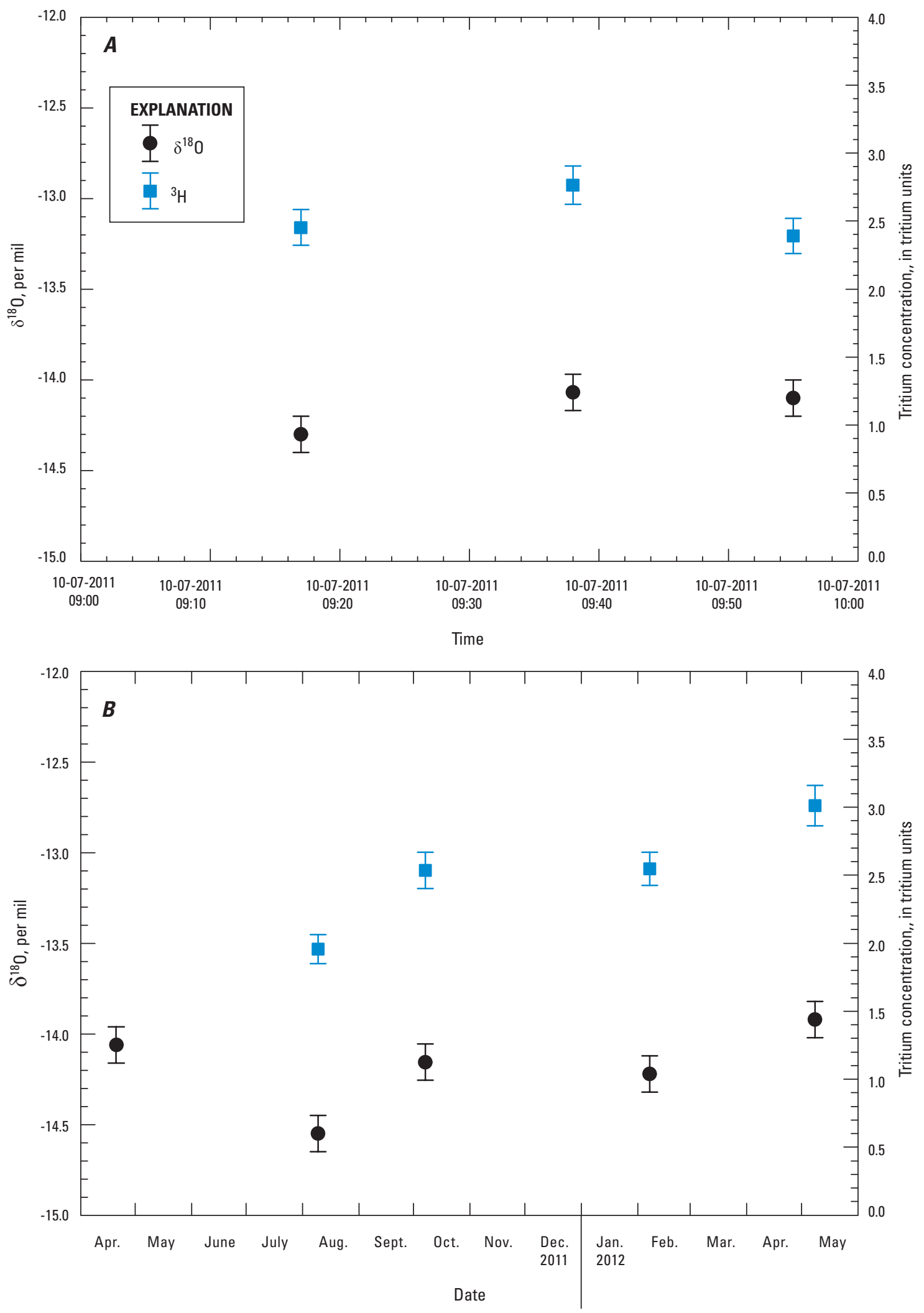

Figure 11. Temporal variability in oxygen isotope $\left(\delta^{18} \mathrm{O}\right)$ and tritium $\left({ }^{3} \mathrm{H}\right)$ values at well $19 \mathrm{~N} / 14 \mathrm{E}-02 \mathrm{C} 01$ in the fractured phyllite aquifer unit, upper Yakima River Basin, Kittitas County, central Washington, $(A)$ variability during pumping on October 7, 2011 and $(B)$ seasonal variability during 2011-12. Error bars show the standard deviations for analytical uncertainty $\left(0.10\right.$ parts per thousand $(\%)$ for $\delta^{18} \mathrm{O}$ and variable for $\left.{ }^{3} \mathrm{H}\right)$. The isotope values shown individually in $(A)$ for 0 ctober 7, 2011 are represented as a single point (mean value) for 0 ctober 7 , 2011 in $(B)$. 


\section{Spatial Patterns of Delta-0xygen-18}

The spatial distribution of $\delta^{18} \mathrm{O}$ values measured in groundwater samples collected from wells is shown in figure 12. Sampling locations were restricted to areas where wells were available; therefore, spatial distribution of sample locations is not uniform. Nevertheless, a clear pattern is evident in which isotopically heavier groundwater tends to be in the western part of the study area, and isotopically lighter groundwater is in the eastern part. To a large extent, this pattern is caused by the so-called "rainout" process that fractionates isotopes in precipitation-as atmospheric moisture masses move above and across land masses, isotopically heavier water molecules preferentially partition into precipitation, a process that leaves residual moisture isotopically lighter (Clark and Fritz, 1997). Thus, downgradient precipitation tends to be isotopically lighter than precipitation falling closer to the sources of moisture (for the most part, the Pacific Ocean in the study area).

Local temperature variations also can have an effect on isotopic fractionation (in addition to the control that temperature has on the process of condensation and thus the production of rain or snow), and other processes may also have an effect (for example, evaporation of moisture from land masses and subsequent incorporation into atmospheric moisture masses). However, the rainout process appears to exert an important effect in the stable isotopic content of groundwater in the upper Kittitas County study area. This isotopic depletion in the eastward direction also was observed in precipitation samples. The pattern of groundwater isotopic depletion in the eastward direction also indicates the presence of subbasin compartmentalization. That is, the spatially distinct stable isotope characteristics of subbasins in the upper Kittitas County study area are consistent with the presence of hydrologically separate subbasins that can be inferred on the basis of topography.

Diversion of river water into irrigation canals and onto agricultural land can alter the distribution of $\delta^{18} \mathrm{O}$ values in groundwater compared to the values that would be evident in a groundwater system recharged solely by precipitation (Vaccaro and others, 2009). For example, well 19N/16E-06E01 (fig. 12) is a shallow (120 ft deep) well in an agricultural area between an irrigation canal and the Yakima River that probably owes its $\delta^{18} \mathrm{O}$ signature $(-12.55 \%)$ to this process.

The spatial distribution of $\delta^{18} \mathrm{O}$ values measured in water samples collected from springs is shown in figure 13. The west-to-east isotopic gradient in samples collected from wells also is evident in samples collected from springs. However, comparing figure 12 with figure 13 shows that the spring samples do not contain the isotopically depleted $\delta^{18} \mathrm{O}$ values that were in the samples from wells. Differences in $\delta^{18} \mathrm{O}$ values between spring and well samples also were evident in figure 10. However, the distributions of sites shown in figures 12 and 13 provide information not evident in figure 10 insofar as they indicate that the depleted $\delta^{18} \mathrm{O}$ values within the network of well samples are unlikely to be a function of different locations across the landscape of the upper Kittitas County study area. This conclusion logically leads to questions about the role of long-term changes in climate on the stable isotopic content of study area groundwater, as long-term changes in climate can lead to profound changes in the stable isotopic content of water recharging aquifers. Effects of longterm climate change are more likely to be evident in deeper, older groundwater than shallower, younger groundwater (shallow wells, spring) and are subsequently discussed in the Carbon-14 and Sulfur Hexafluoride section of this report.

The spatial distribution of $\delta^{18} \mathrm{O}$ values measured in samples collected from small streams is shown in figure 14 . Although more geographically limited in extent than the groundwater samples, these small-stream sites still exhibit west-to-east isotopic fractionation. Small-stream $\delta^{18} \mathrm{O}$ values (fig. 14) are similar to values from springs (fig. 13), and are quite different from "summer" precipitation (fig. 10), reflecting the importance of groundwater in sustaining streamflow.

\section{Tritium}

Tritium is a radioactive isotope of hydrogen with a halflife of 12.32 years (Lucas and Unterweger, 2000). Tritium concentrations in precipitation have varied tremendously over recent decades. Prior to 1953, concentrations of ${ }^{3} \mathrm{H}$ in precipitation in the study area were about 4 tritium units (TU) (Thatcher, 1962). This ${ }^{3} \mathrm{H}$ level represented natural background ("pre-bomb") concentrations that existed prior to widespread atmospheric testing of thermonuclear weapons. Atmospheric testing of thermonuclear weapons injected large quantities of ${ }^{3} \mathrm{H}$ into the atmosphere, and ${ }^{3} \mathrm{H}$ concentrations in precipitation increased markedly in the 1950s. Tritium concentrations peaked in the northern hemisphere in 1963 and have since decreased to near-background levels.

The estimated ${ }^{3} \mathrm{H}$ input function for the study area is shown in figure 15. Estimates of ${ }^{3} \mathrm{H}$ in precipitation from August 1953 through December 2001 were based on interpolation of International Atomic Energy Agency (IAEA) data from long-term stations in the conterminous United States. Missing IAEA temporal records were populated with values based on correlation using long-term datasets from Ottawa, Canada (August 1953-December 1987) and Vienna, Austria (January 1988-December 2001). Tritium concentrations prior to August 1953 were assumed to be $4 \mathrm{TU}$ (Thatcher, 1962). For post- $2001{ }^{3} \mathrm{H}$ concentrations, least squares regression was used to estimate an exponential decrease in ${ }^{3} \mathrm{H}$, constrained by the $4 \mathrm{TU}$ pre-bomb estimate; extrapolation was based on the 20-year period January 1982-December 2001. 


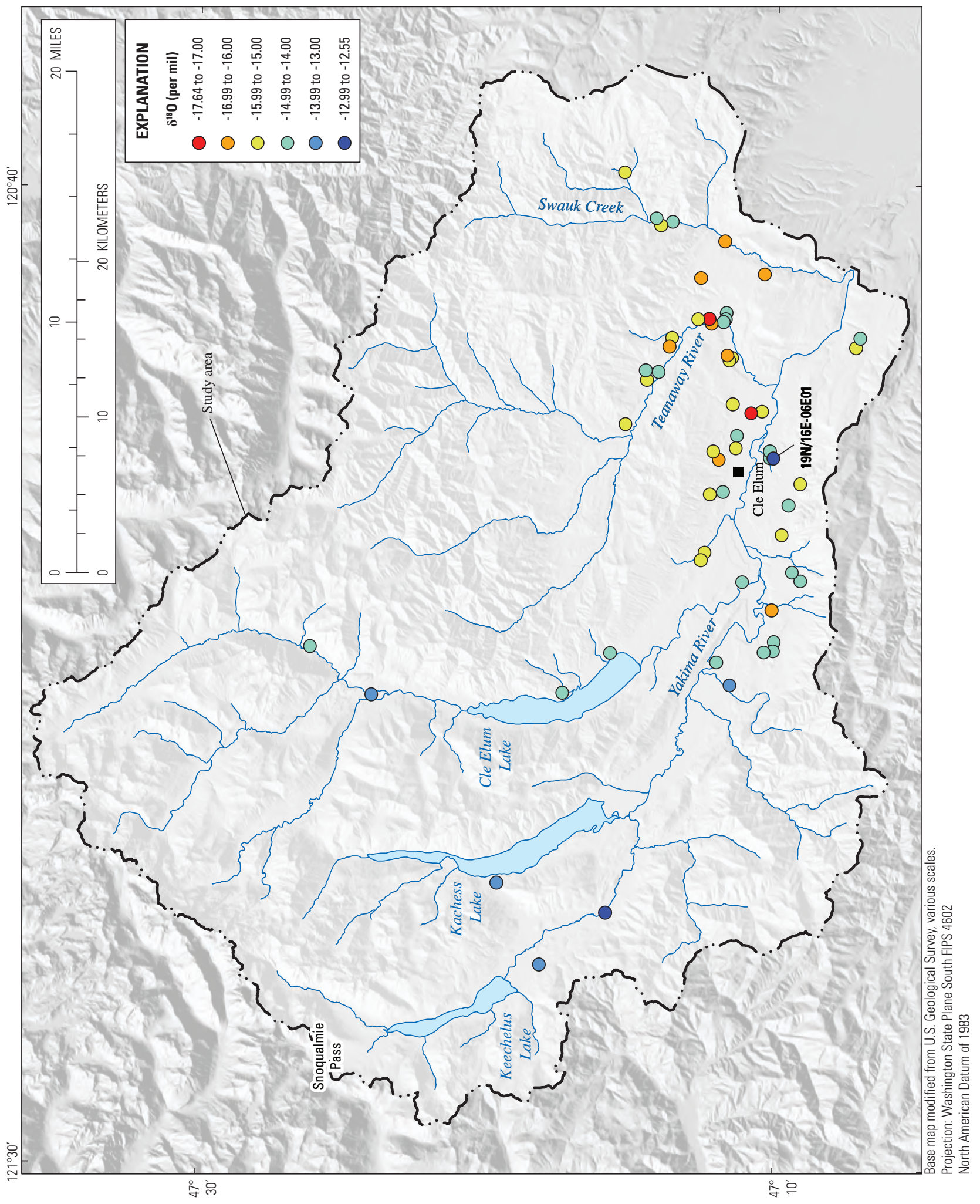

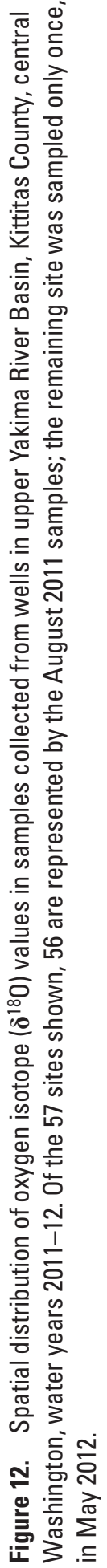



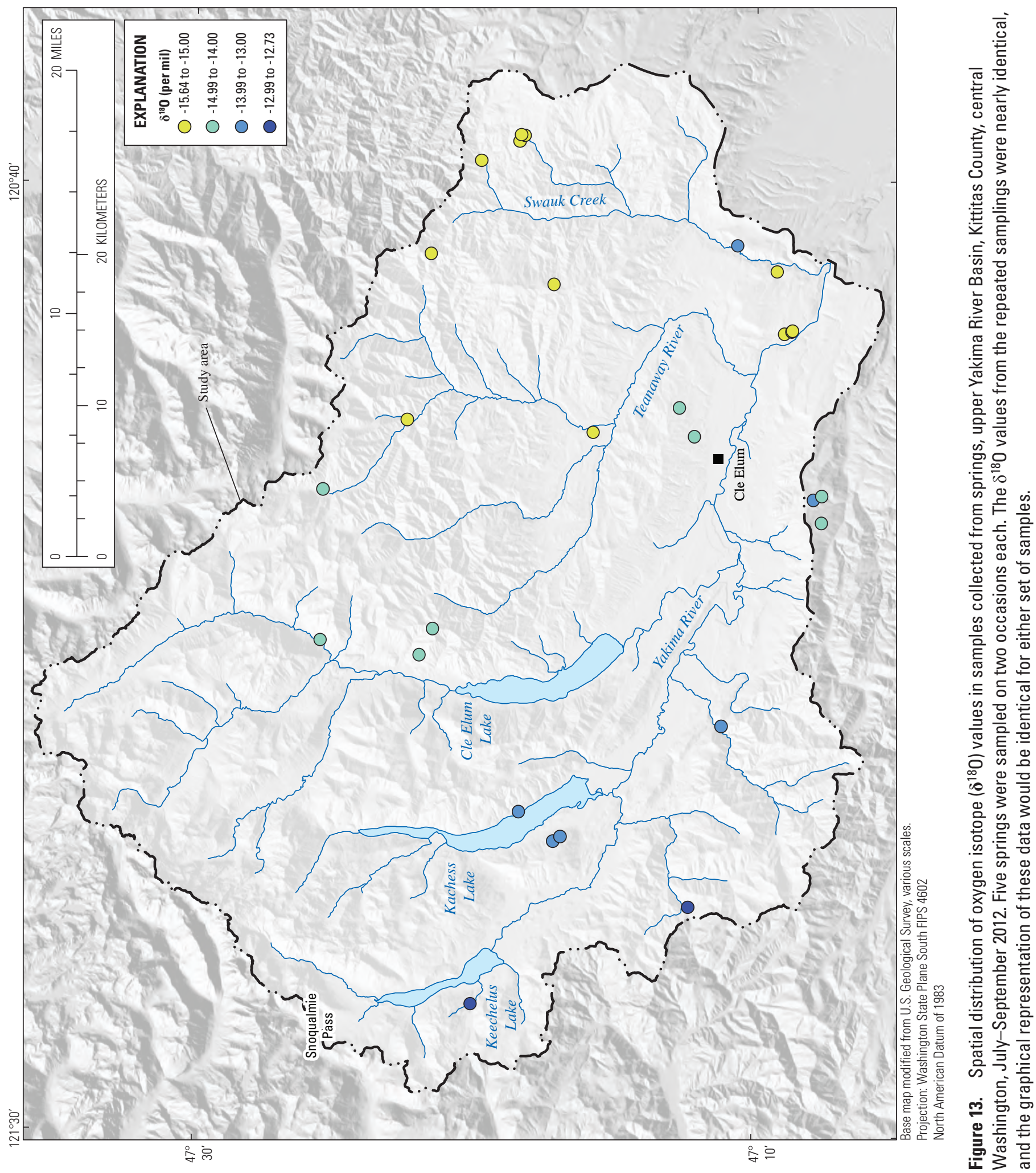


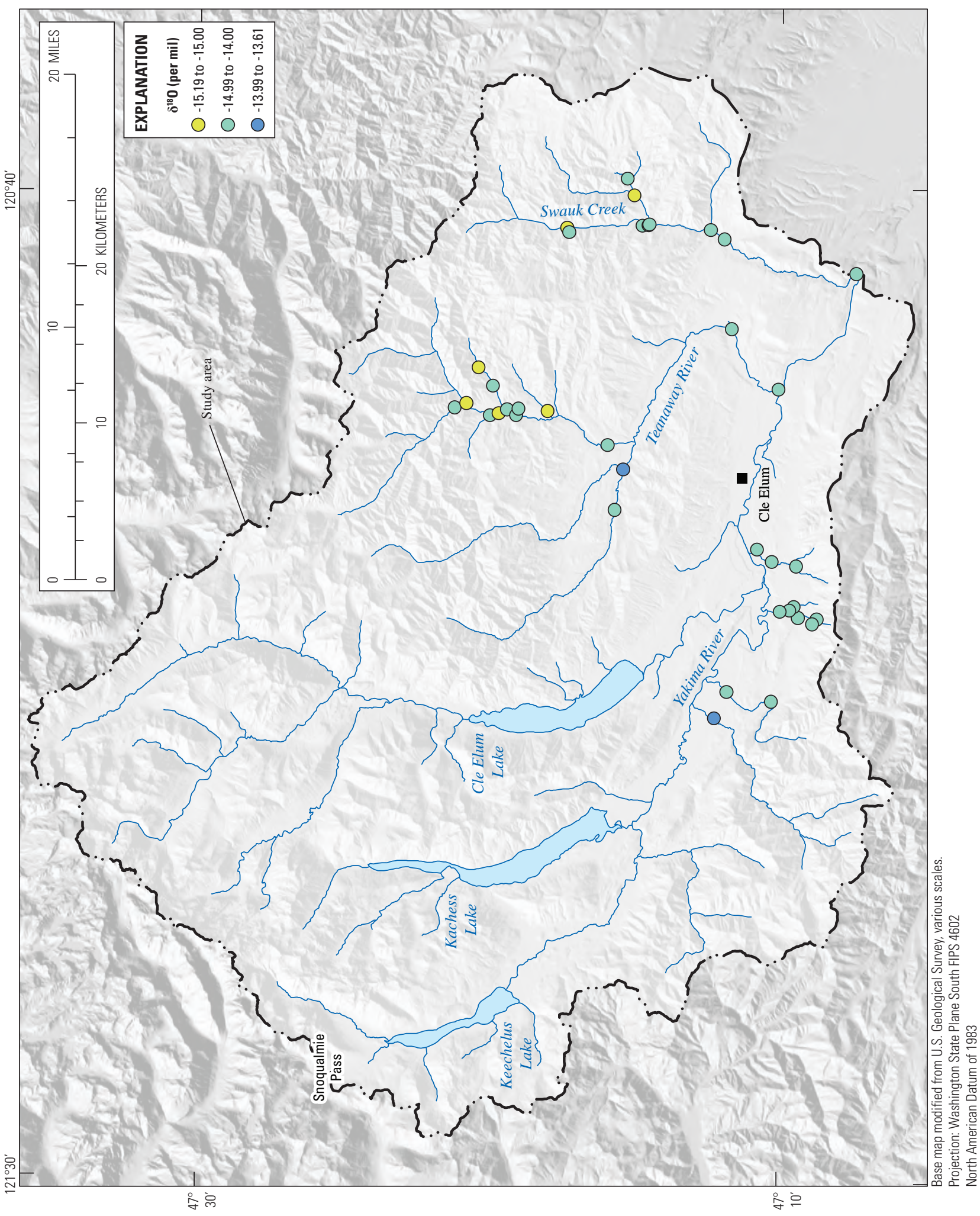

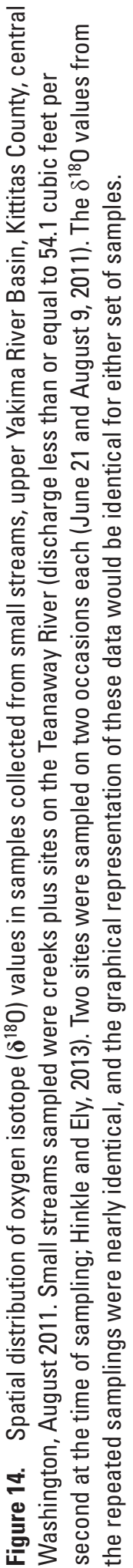




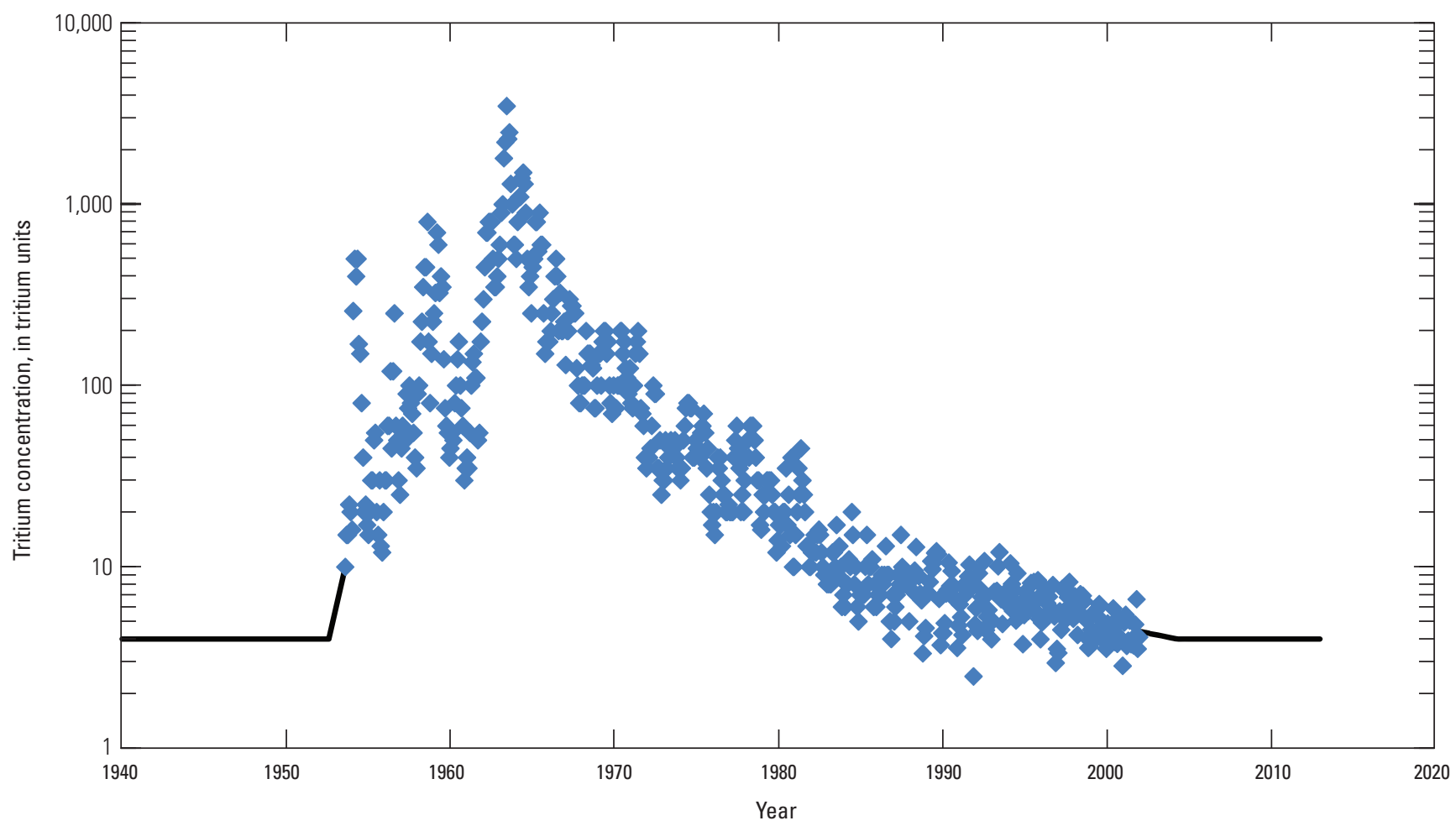

Figure 15. Reconstructed tritium input function for the upper Yakima River Basin, Kittitas County, central Washington. The vertical axis has a logarithmic scale.

Spatial variability in ${ }^{3} \mathrm{H}$ inputs is minor at the scale of the study area (Thatcher, 1962). Variability in groundwater ${ }^{3} \mathrm{H}$ concentrations reflects a combination of historical variability in ${ }^{3} \mathrm{H}$ inputs to land surface and variability in groundwater time-of-travel from land surface to downgradient sampling points such as wells. The time-dependent decay of ${ }^{3} \mathrm{H}$ can be exploited for characterization of groundwater time-of-travel, but the thermonuclear bomb pulse adds complications that often lead to ${ }^{3} \mathrm{H}$ being used as a simple indicator of the presence or absence of "post-bomb” (post1952) recharge. In the upper Kittitas County study area, groundwater entering an aquifer with the estimated pre-bomb ${ }^{3} \mathrm{H}$ concentration of $4 \mathrm{TU}$ in 1952 would have decayed to 0.14 TU by 2011. In the absence of mixing along groundwater flow paths, a ${ }^{3} \mathrm{H}$ concentration of less than $0.14 \mathrm{TU}$ would indicate groundwater recharged prior to 1953 . However, before assessing the spatial distribution of ${ }^{3} \mathrm{H}$ in study area groundwater, analysis of temporal variability in ${ }^{3} \mathrm{H}$ concentrations is informative.

Temporal variability in ${ }^{3} \mathrm{H}$ concentrations, during well purging and at the seasonal scale, was investigated at selected sites. Variability during well purging was assessed with six sets of replicate samples (five sets of triplicates and one set of quadruplicates). Data for one of these wells (19N/14E-02C01) are plotted in figure 11A. The timescale of well purging is much shorter than the timescale of variability in ${ }^{3} \mathrm{H}$ inputs (fig. 15), and the variability observed in these well-purging samples likely reflects a combination of analytical variability and groundwater contribution variability to sampled wells. Standard deviations in environmental ${ }^{3} \mathrm{H}$ samples range from 0.03 to 0.25 TU, whereas laboratory standard deviations (which are variable, depending in part on ${ }^{3} \mathrm{H}$ concentration and background radiation during sample measurement) ranged from 0.08 to $0.17 \mathrm{TU}$. The two sites at which environmental sample standard deviations exceeded laboratory standard deviations (19N/14E-02C01 and 19N/14E-02F01) were in metamorphic rock, a fractured medium that can be associated with complicated flow dynamics. At one of these sites in metamorphic rock, seasonal variability also is evident (fig. 11B). The standard deviation for these seasonal samples is $0.43 \mathrm{TU}$, somewhat greater than the standard deviation in the samples collected during well purging (0.20 TU).

Variability in ${ }^{3} \mathrm{H}$ concentrations over seasonal timescales could be related to time-varying inputs to an aquifer, if some of the pathways from recharge areas to a sampled well transmit water sufficiently quickly. Alternatively, observed variability in ${ }^{3} \mathrm{H}$ concentrations over seasonal timescales could indicate that fractures or pathways that contribute water to the well have varying degrees of connectivity at this timescale, owing to changes in degree of fracture saturation or connectivity. The similar patterns of variability in stable isotopes of water and ${ }^{3} \mathrm{H}$ in figure 11 could be consistent with 
either one of these hypotheses, and again demonstrate the dynamic nature of groundwater flow in fractured rock aquifers.

The spatial variability in ${ }^{3} \mathrm{H}$ concentrations in the vertical dimension of upper Kittitas County study area groundwater is shown in figure 16. Concentrations of ${ }^{3} \mathrm{H}$ were calculated by subtracting natural background radiation from radiation measured in the sample; in low- ${ }^{3} \mathrm{H}$ samples, this can result in slightly negative ${ }^{3} \mathrm{H}$ concentrations because of uncertainty in quantifying the variable background radiation. Of the 57 sites shown in figure 16, 56 are represented by the August 2011 samples; the remaining site was sampled only once, in May 2012, and therefore is represented by the May 2012 sample. Tritium concentrations ranged from near 0 TU to as much as 5.4 TU. Environmental variability in these samples greatly exceeds observed temporal variability.

Data for all 57 sites are shown in figure 16A. Data for sub-groups, based on geology, are shown in figure 16B (unconsolidated sediments), figure 16C (sedimentary rocks), and figure 16D (flood basalts and other volcanic, metamorphic, and intrusive rocks). Geology for site 21N/12E-36Q01 was a combination of volcanic and sedimentary rocks and is plotted here with sedimentary rocks because its well log indicated that sandstone was the primary water-producing interval. Also shown in these figures is the vertical extent of the open interval of each well. Many wells have long open intervals. This is particularly evident for wells in the sedimentary rock unit (fig. 16C), reflecting the poor well yield common in that aquifer unit. The relatively short open intervals associated with unconsolidated sediments (fig. 16B) indicate a generally more productive aquifer unit, consistent with the widespread presence of permeable unconsolidated sediments throughout the larger Yakima River Basin (Vaccaro and others, 2009).

The decrease in ${ }^{3} \mathrm{H}$ concentration with increasing depth below the potentiometric surface (fig. 16A) indicates that young (that is, post-bomb) groundwater resides primarily at shallower depth in these aquifer units. Generally-lower ${ }^{3} \mathrm{H}$ concentrations in deep zones indicate that groundwater in deep zones is replenished on a timescale that often exceeds the timescale of ${ }^{3} \mathrm{H}$ dating. One-third of the sites contained ${ }^{3} \mathrm{H}$ concentrations of less than $0.14 \mathrm{TU}$, indicating essentially 100 percent pre-bomb water; other low- ${ }^{3} \mathrm{H}$ samples likely represent a mixture of pre-bomb water with small amounts of post-bomb water. Pre-bomb ${ }^{3} \mathrm{H}$ concentrations were detected in all the major geologic groups shown in figures 16B-D. Pre-bomb sites do include both shallow and deep wells (fig. 16). Some of the occurrences of low- ${ }^{3} \mathrm{H}$ groundwater at shallow depths probably reflects the fact that old groundwater that has traveled through the aquifer for long periods of time and that has not been captured by wells eventually discharges either to streams (or to the near-stream environment, where it can exit the groundwater system by evapotranspiration). In other words, groundwater that discharges to streams represents groundwater at the distal end of flow paths, and the final segments of such flow paths must pass through the shallow aquifer materials in order to reach those streams. Tritium data indicate that some of this end-of-flow path groundwater moves at timescales of decades or more.

\section{Carbon-14 and Sulfur Hexafluoride}

Groundwater samples from selected sites were analyzed for the environmental tracers ${ }^{14} \mathrm{C}$ and $\mathrm{SF}_{6}$. These environmental tracers provide insights into the age of groundwater that are not evident from analysis of ${ }^{3} \mathrm{H}$ alone.

Sulfur hexafluoride is a compound that has both natural and anthropogenic sources. Anthropogenic $\mathrm{SF}_{6}$ volatilizes into the atmosphere, where it greatly exceeds $\mathrm{SF}_{6}$ derived from natural sources. Atmospheric $\mathrm{SF}_{6}$ concentrations have been increasing from the 1970s through the present. Atmospheric $\mathrm{SF}_{6}$ partitions by gas/liquid partitioning into water that is in contact with the atmosphere. In this manner, groundwater obtains an $\mathrm{SF}_{6}$ signature at the time of recharge, and the timevariant concentrations of $\mathrm{SF}_{6}$ in the atmosphere facilitate the use of $\mathrm{SF}_{6}$ in age-dating applications where natural sources of $\mathrm{SF}_{6}$ in the aquifer are absent or negligible (Busenberg and Plummer, 2000).

Carbon-14 is naturally present in Earth's atmosphere and biosphere. Atmospheric carbon dioxide $\left(\mathrm{CO}_{2}\right)$ is partitioned into water that is in contact with the atmosphere. Additional $\mathrm{CO}_{2}$ is partitioned into unsaturated-zone water by the microbially mediated oxidation of organic carbon and root respiration. These processes deliver ${ }^{14} \mathrm{C}$ to groundwater. The time-dependent radioactive decay of ${ }^{14} \mathrm{C}$ as groundwater moves through aquifers can be used in age-dating applications. The half-life of ${ }^{14} \mathrm{C}$ is 5,730 years; therefore, changes in ${ }^{14} \mathrm{C}$ concentration along flow paths can be used to estimate groundwater ages of as much as several tens of thousands of years. However, there are complications in the interpretation of ${ }^{14} \mathrm{C}$ data. One of these complications is that DIC in water can be diluted with ${ }^{14} \mathrm{C}$-free (so-called " ${ }^{14} \mathrm{C}$-dead") carbon in aquifers, leading to decreases in ${ }^{14} \mathrm{C}$ concentrations along groundwater flow paths. Sources of ${ }^{14} \mathrm{C}$-dead carbon in aquifers can include dissolution of sedimentary organic material or calcite (including pedogenic calcite in basalt interflow zones and hydrothermally emplaced calcite), and additions of magmatic $\mathrm{CO}_{2}$. Exchange of carbon atoms in groundwater with carbon atoms in the aquifer, and diffusion of ${ }^{14} \mathrm{C}$ into confining units, also can dilute ${ }^{14} \mathrm{C}$ in DIC. Such limitations complicate age-dating with ${ }^{14} \mathrm{C}$. Note that most laboratories report "normalized" ${ }^{14} \mathrm{C}$ values, where ${ }^{14} \mathrm{C}$ concentrations are adjusted based upon assumptions of "normal" $\delta^{13} \mathrm{C}$ values (Stuiver and Polach, 1977). For groundwater studies, ${ }^{14} \mathrm{C}$ values should be denormalized because groundwater $\delta^{13} \mathrm{C}$ values are expected to deviate from initial values as a result of water/rock interactions (Kalin, 2000). Denormalized ${ }^{14} \mathrm{C}$ values are presented in this report. 


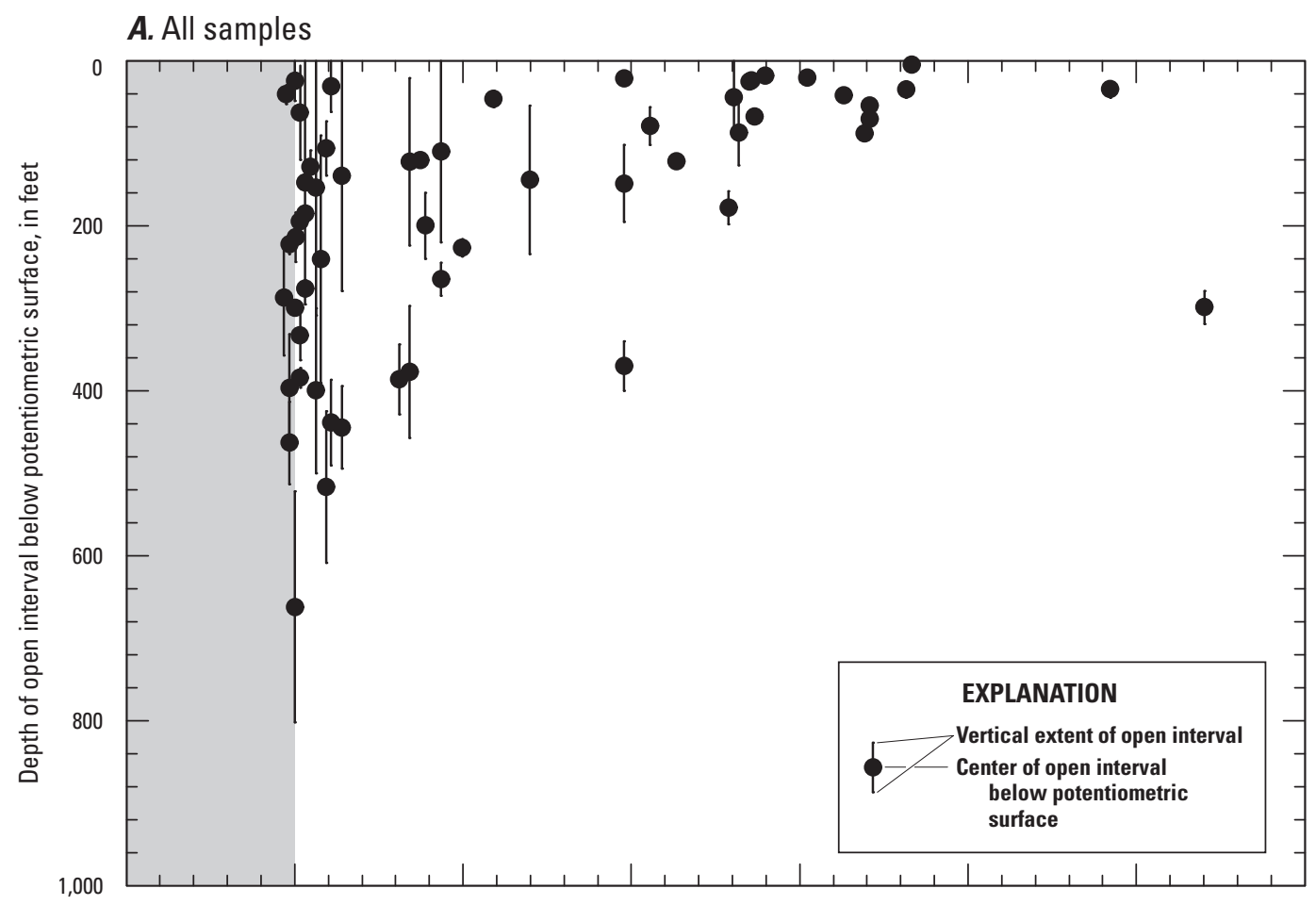

B. Unconsolidated sediment

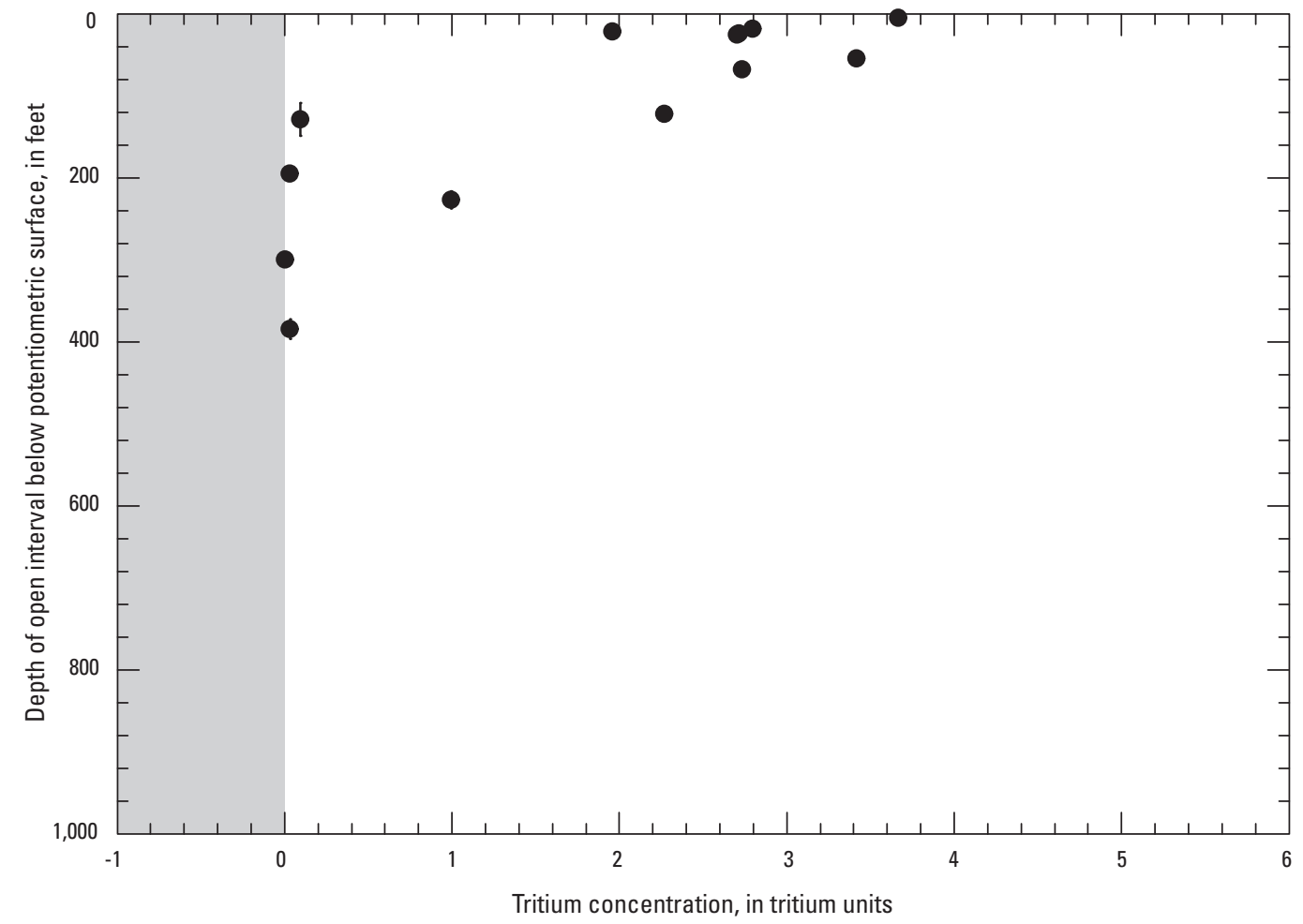

Figure 16. Vertical distribution of tritium concentrations from $(A)$ all samples, $(B)$ unconsolidated sediment, $(C)$ sedimentary rocks, and $(D)$ flood basalt and other volcanic, metamorphic, and intrusive rocks in water samples collected from wells, upper Yakima River Basin, Kittitas County, central Washington, 2011-12. Shaded area indicates negative tritium (3H) concentrations. 


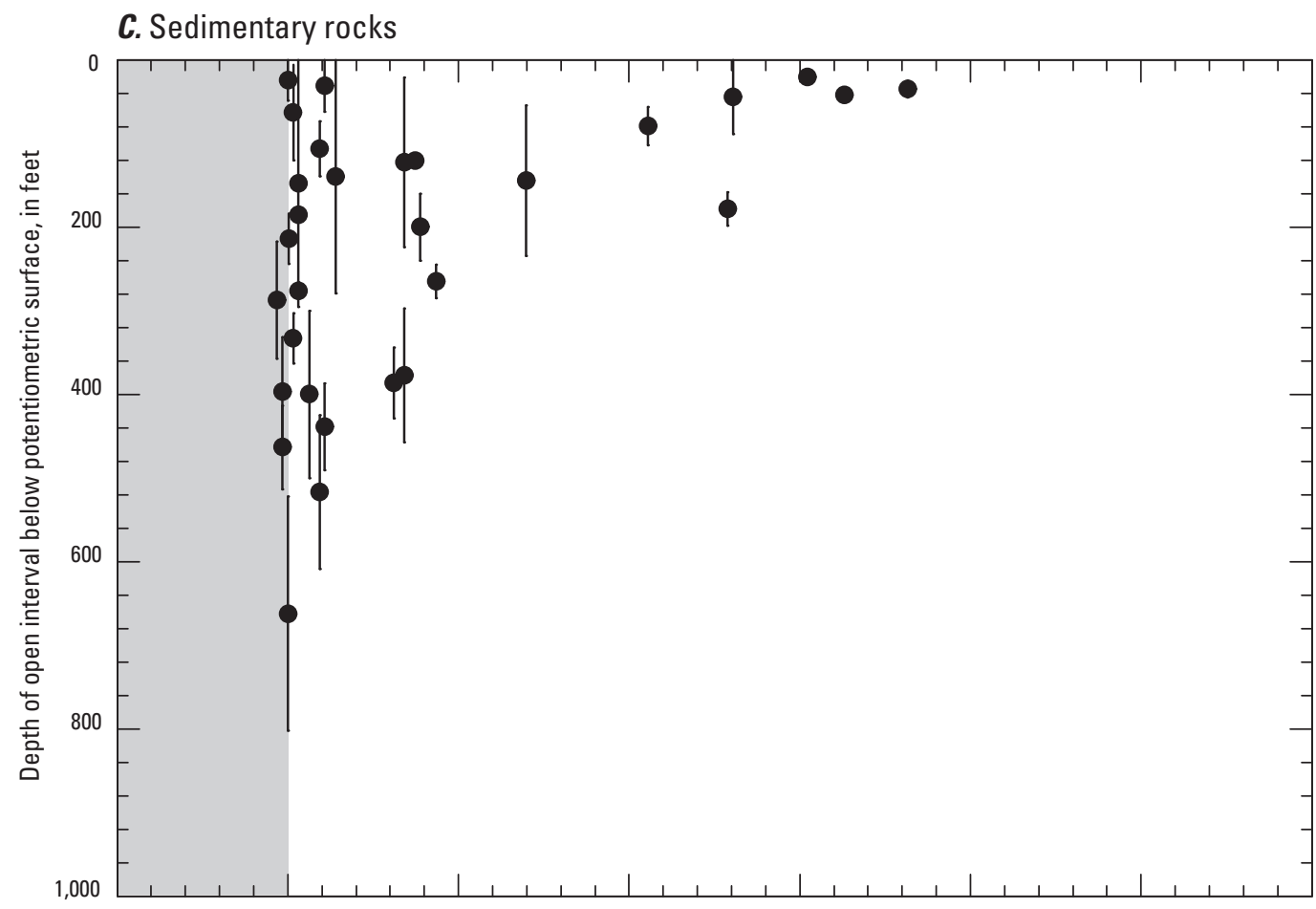

D. Flood basalt, other volcanic rocks, metamorphic rocks, and intrusive rocks

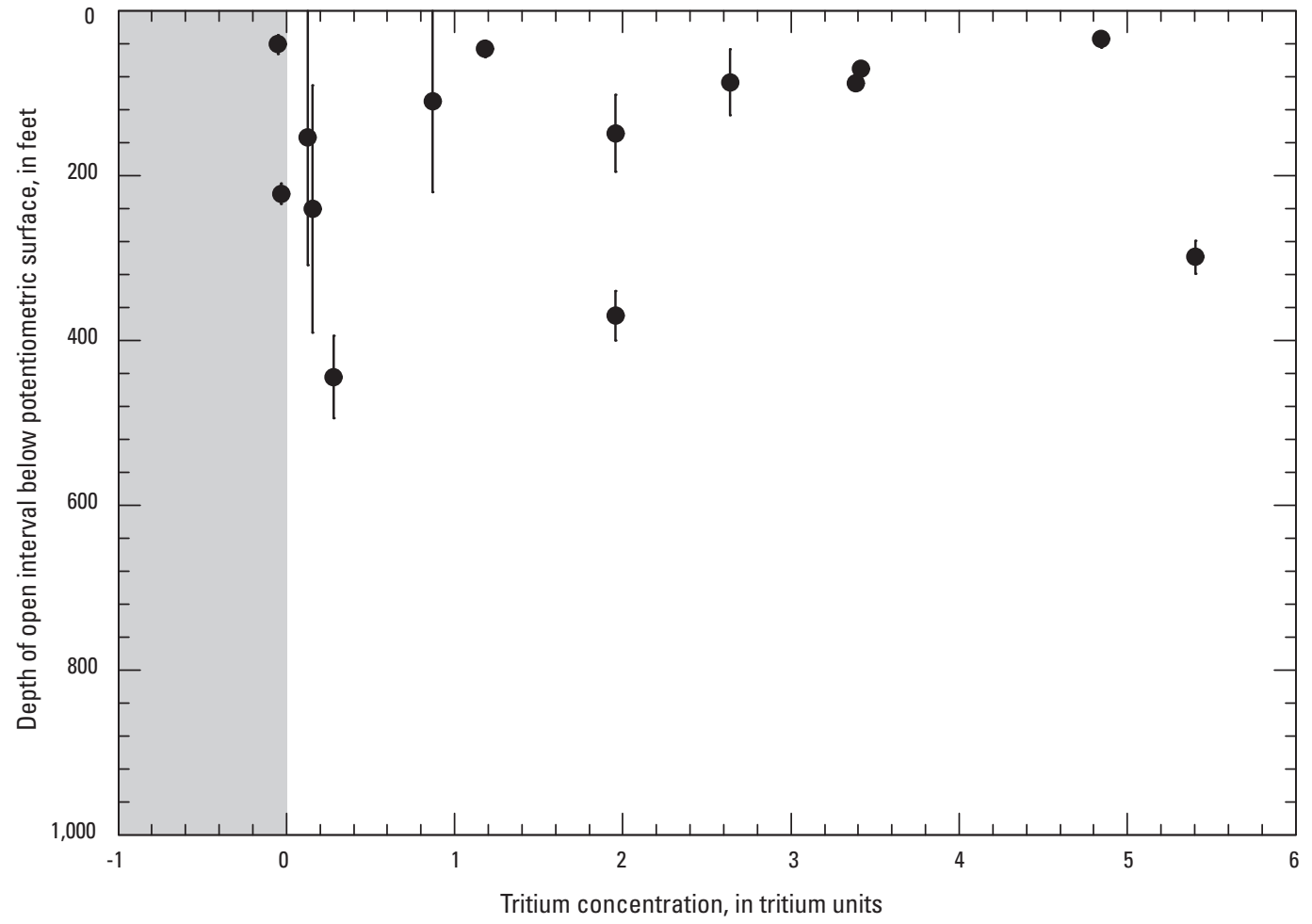

Figure 16.-Continued 
Six wells were selected for sampling and analysis of carbon isotopes $\left(\delta^{13} \mathrm{C}\right.$ and $\left.{ }^{14} \mathrm{C}\right)$ and, where sampling conditions allowed, $\mathrm{SF}_{6}$ (table 3). The locations of these sites are identified in figure 9 . The collection of these additional environmental tracer data, along with analysis for inorganic constituents such as the dominant ions in solution, allows for an analysis of a range of geochemical conditions that may allow extrapolation to the larger system. The six wells were completed in metamorphic or sedimentary rocks. These sites were selected to provide some variety in hydrogeologic settings, with an emphasis on deeper groundwater that were hypothesized (based on position in the flow system or data on the stable isotopes of water) to contain components of old groundwater. The six sites are ordered in table 3 by decreasing ${ }^{14} \mathrm{C}$ concentration, and are referred to by sequence number in table 3 (that is, $1-6$ ).

Site 1 represents upgradient groundwater in the upper Kittitas County study area. It is on the flanks of the basin; land surface slope reflects the position of this site off of the basin floor (table 3). Site 1 is one of the shallowest wells in table 3. Tritium data $(3.0 \mathrm{TU})$ confirm the presence of postbomb water. The major-cation composition of groundwater from this site is dominated by divalent cations, reflecting groundwater that has not undergone extensive geochemical evolution (for example, Hearn and others, 1985; Hem, 1985) and is consistent with the presence of young groundwater.

Site 2 represents groundwater with an intermediate degree of hydrologic evolution. Site 2 is a flowing well close to $(<200 \mathrm{ft}$ from) the Yakima River. Tritium data $(0.78 \mathrm{TU})$ indicates at least a component of post-bomb water. The major-cation composition of groundwater from this site is intermediate between water collected at site 1 and that collected from sites 3-6, indicating groundwater that has undergone an intermediate degree of geochemical evolution. The location of site 2 indicates end-of-flow path groundwater, but this site- one of the western-most wells measured during this study—is located in a zone of regionally steep topographic relief and is a zone that has some of the highest rates of recharge in the Yakima Basin (Vaccaro and others, 2009; Ely and others, 2011) and likely is associated with faster rates of groundwater movement compared to similar sites farther east in the upper Kittitas County study area.

Site 3, a shallow well (top of open interval $60 \mathrm{ft}$ below land surface) on the basin floor and near (about 1,000 $\mathrm{ft}$ from) the Teanaway River, apparently is in a zone of temporally changing groundwater flow. Samples collected May 2012 contained low concentrations of ${ }^{14} \mathrm{C}$, high $\mathrm{pH}$, and a chemically evolved chemical composition dominated by (99 percent) monovalent cations (table 3), all consistent with old groundwater. However, samples for stable isotopes of water and ${ }^{3} \mathrm{H}$ were collected August 2011 (not repeated May 2012), and these samples contained $2.1 \mathrm{TU}$ of ${ }^{3} \mathrm{H}$, clearly indicating the presence of post-bomb water. The May 2012 samples were not likely to represent a mixture of old (low${ }^{14} \mathrm{C}$ ) and young (tritiated) components; the overwhelmingly monovalent-cation composition of the May 2012 samples suggests an absence of young water in those samples. Site 3 is surrounded by agricultural fields, possibly irrigated with Teanaway River water that may lead to a transient surfacewater signature for this site; the similarity in August $2011 \delta^{18} \mathrm{O}$ values for site 3 (14.58\%) and the closest Teanaway River site $(-14.59 \%)$ is consistent with this hypothesis. The apparent temporal geochemical variability at this site is consistent with the shallow depth and neighboring land use, leading to the conclusion that this site represents a dynamic zone; however, for the purposes of geochemical analysis, this site is excluded from additional analysis in this report owing to the uncertainty associated with this site.

Sites 4, 5, and 6 represent deep, downgradient groundwater (table 3). Site 4 is in a broad, topographically flat terrace (labeled "Swauk Prairie" on the USGS 7.5” topographic map of the same name). Site 5 and 6 are on the basin floor. The three sites yield pre-bomb water, and the major-cation compositions are dominated by monovalent cations, indicating an advanced degree of geochemical evolution (Hearn and others, 1985; Hem, 1985).

Environmental tracer data demonstrate an age progression in these groundwater samples. Site 1 is characterized by young groundwater. Sulfur hexafluoride concentrations were equivalent to 86 percent of year-2012 atmospheric levels. For piston-flow (non-mixing groundwater) conditions, this level of $\mathrm{SF}_{6}$ would equate to 4-year-old groundwater, although a mixture of ages both younger and older than this piston-flow age likely is present. Carbon 14 concentrations (about 85 $\mathrm{PMC}$ ) and ${ }^{3} \mathrm{H}$ data are consistent with young recharge. Site 2 could represent a mixture of pre- and post-bomb water. Sulfur hexafluoride concentrations were equivalent to 8.7 percent of year-2012 atmospheric levels. For piston-flow conditions, this would equate to recharge in 1978. However, ${ }^{3} \mathrm{H}$ concentrations were too low for 1978 recharge, and consideration of the $\mathrm{SF}_{6}$ and ${ }^{3} \mathrm{H}$ data together indicates the presence of a groundwater mixture. Carbon-14 concentrations (52 percent modern) could be consistent with a mixture of young and pre-bomb groundwater. Sites 4, 5, and 6 are characterized by old groundwater. Tritium concentrations were essentially zero. Sulfur hexafluoride concentrations for site 4 are reported in $\underline{\text { table } 3}$, but were below the dating range for the method $\left(\mathrm{SF}_{6}\right.$ at levels that can be attributed to exchange with laboratory air; Plummer and others, 2012). Carbon-14 concentrations (about 11-24 percent modern) are consistent with old groundwater. 

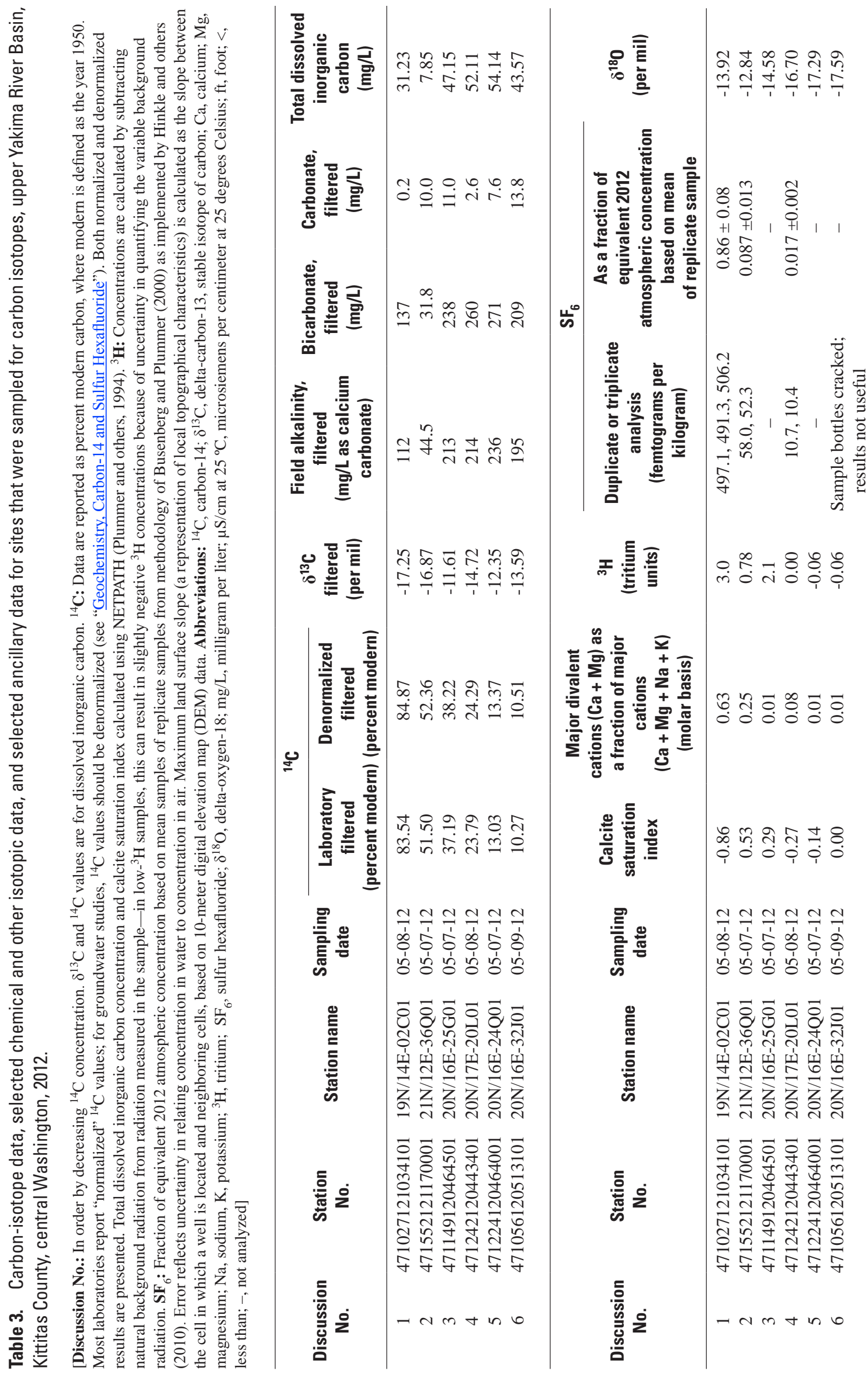

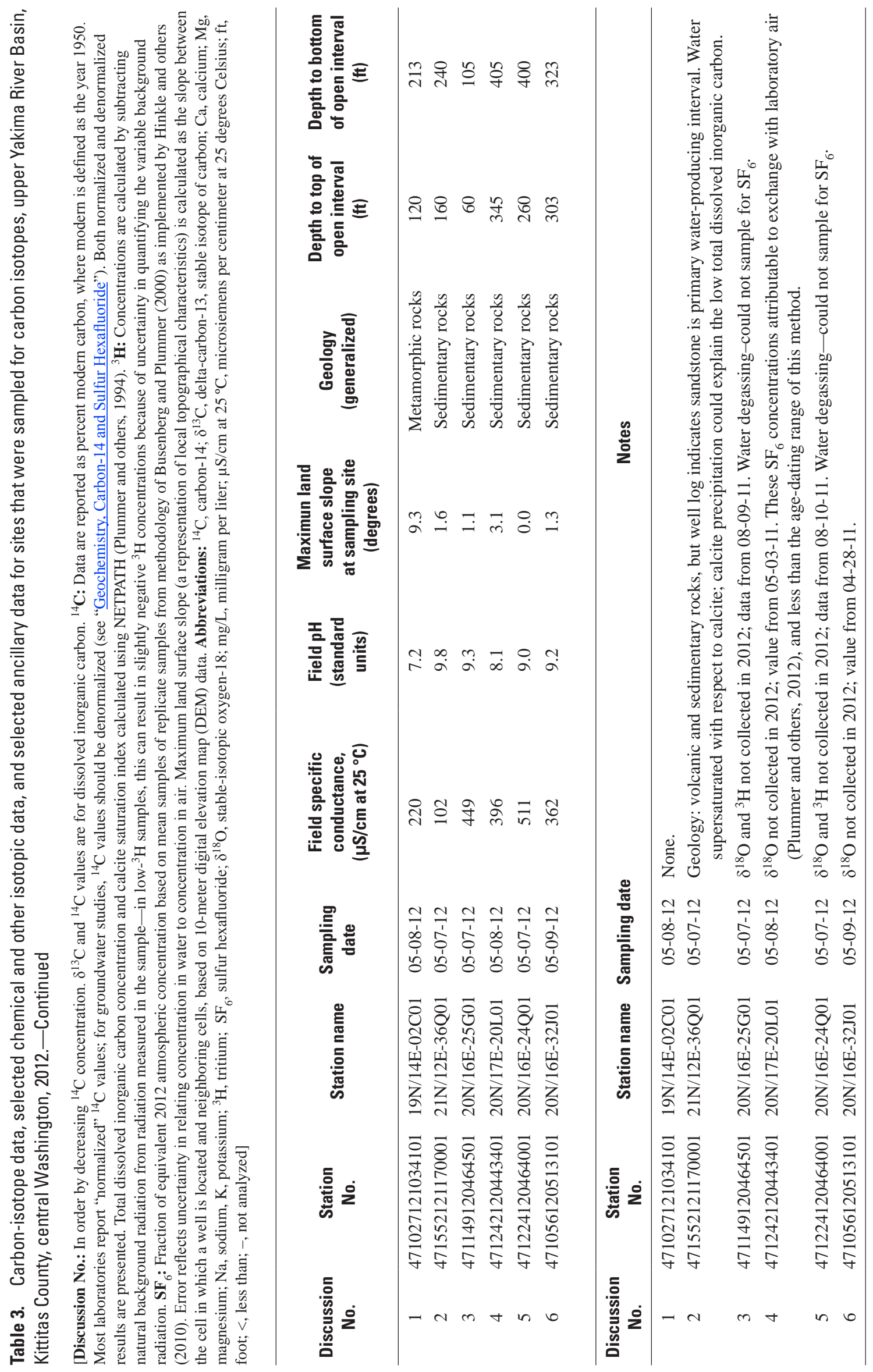
The age of the low $-{ }^{14} \mathrm{C}$ groundwater could equate to piston-flow ages as great as 19,000 years (site 6) if it is assumed that the ${ }^{14} \mathrm{C}$ concentration present in groundwater during recharge at the beginning of groundwater flow paths was 100 PMC (the atmospheric concentration present in 1950, before widespread thermonuclear weapons testing increased atmospheric concentrations of ${ }^{14} \mathrm{C}$ ) and that no carbon mass transfers occurred as groundwater moved through aquifers to downgradient wells (for example, mineral dissolution or ${ }^{14} \mathrm{C}$ diffusion into confining units). However, atmospherically derived ${ }^{14} \mathrm{C}$ often becomes diluted with ${ }^{14} \mathrm{C}$-dead carbon. Processes that dilute ${ }^{14} \mathrm{C}$ in groundwater often begin at the most upgradient locations of groundwater flow paths. For example, analysis of ${ }^{14} \mathrm{C}$ content of shallow groundwater in Columbia River Basalt aquifers has yielded estimates of initial ${ }^{14} \mathrm{C}$ content of 80-85 PMC (Yakima River Basin; Vaccaro and others, 2009) and 75 PMC at the U.S. Department of Energy Hanford Site (Reidel and others, 2002). Dilution of ${ }^{14} \mathrm{C}$ often continues as groundwater moves away from recharge zones and flows through and interacts with aquifers. The $\delta^{13} \mathrm{C}$ values for downgradient groundwater (sites 4-6) reflect such carbon additions; carbon in calcite is isotopically enriched relative to most other carbon sources in groundwater (Plummer and others, 1994), and the relatively enriched $\delta^{13} \mathrm{C}$ values for the downgradient groundwater are consistent with additions of isotopically enriched carbon from calcite dissolution plus other carbon sources.

A refined assessment of ${ }^{14} \mathrm{C}$ data can include adjustments for carbon additions. For example, if site 1 (the young, upgradient well in table 3) is assumed to be representative of recharge water in the upper Kittitas County study area and differences in total dissolved inorganic carbon between site 1 and site 6 are assumed to represent carbon additions that were devoid of ${ }^{14} \mathrm{C}$, an adjusted ${ }^{14} \mathrm{C}$-based piston-flow age can be estimated. The 84.87 PMC ${ }^{14} \mathrm{C}$ concentration for site 1 likely reflects a combination of the addition of thermonuclear ${ }^{14} \mathrm{C}$ (present in post-1950 precipitation; Kalin, 2000) and the dilution of ${ }^{14} \mathrm{C}$ from accumulations of ${ }^{14} \mathrm{C}$-dead carbon in groundwater to the location of site 1 . For the estimate of groundwater age derived here, an initial ${ }^{14} \mathrm{C}$ concentration at site 1 of 80 PMC was assumed (Reidel and others, 2002; Vaccaro and others, 2009). This adjustment from a measured ${ }^{14} \mathrm{C}$ concentration of about $85 \mathrm{PMC}$ to an assumed concentration of 80 PMC for initial ${ }^{14} \mathrm{C}$ concentration accounts for the absence of thermonuclear ${ }^{14} \mathrm{C}$ in recharge water that would have entered these aquifer systems in the distant past. Under these assumptions, the adjusted ${ }^{14} \mathrm{C}$-based piston-flow age for site 6 would be 14,000 years, a timeframe that would equate to a different climate than is present in 2013. Similar timescales of groundwater age have been estimated for deep groundwater in Columbia River Basalt in parts of the Columbia Plateau (Kahle and others, 2011).
These scenarios for interpretation of ${ }^{14} \mathrm{C}$ data provide constraints on groundwater age, and thus on groundwater dynamics in the upper Kittitas County study area. However, these scenarios rely on simplifying assumptions that lead to uncertainties in the age estimates. Among these limiting assumptions are (1) that the geochemistry of site 1 is representative of upgradient groundwater that eventually flows to the locations of the downgradient sites, and (2) that groundwater at downgradient sites represents unmixed groundwater. Although the geochemistry of groundwater at site 1 does represent young groundwater that has experienced only limited water/rock interaction, it can be expected that the geochemistry of groundwater near the beginning of most flow paths would have differed somewhat from that associated with site 1 , thus requiring different carbon mass transfers to achieve the end-of-flow path chemistry represented by downgradient wells. These differences, in turn, could lead to increases or decreases in ${ }^{14} \mathrm{C}$-based piston-flow ages. The effect of groundwater mixing is such that downgradient groundwater might consist of components both older and younger than those indicated by simplistic ${ }^{14} \mathrm{C}$-based piston-flow ages. Some of the limitations of ${ }^{14} \mathrm{C}$-dating can be minimized by working with wells constructed with short open intervals and located along well-constrained groundwater flow paths (an option that was not available in this study). In spite of these stated limitations, though, the ${ }^{14} \mathrm{C}$ data do indicate that some of the deeper groundwater in the upper Kittitas County study area likely contains at least components of water sufficiently old to have been recharged during the Pleistocene. This finding has implications for the timescales of groundwater replenishment and for interpretation of data on stable isotopes of water in upper Kittitas County study area groundwater.

Groundwater system stresses (for example, groundwater pumping or climatically caused changes in aquifer recharge) may have different effects where applied to young, upgradient groundwater compared with old, downgradient groundwater. For example, parts of the aquifer system that occur in upland zones and contain the youngest groundwater might be most sensitive to changes in recharge, owing to the fact that such upgradient groundwater is most closely connected to recharge fluxes entering the aquifer system. Parts of the aquifer system that occur in deep, low-hydraulic-gradient zones and contain components of Pleistocene age recharge may be less sensitive to changes in current recharge. The effects of groundwater pumping can differ from the effects of changing recharge. Groundwater withdrawals capture groundwater that eventually would have flowed to streams. However, withdrawal of nearstream groundwater (such as some of the groundwater associated with low ${ }^{14} \mathrm{C}$ concentrations) can, if large enough in magnitude, induce direct streamflow losses. Withdrawals from recharge-area wells are unlikely to directly induce streamflow losses, although such pumping still captures groundwater that would otherwise have flowed to streams. 
The presence of Pleistocene groundwater has implications for interpretation of data on the stable isotopes of water insofar as Pleistocene recharge in many temperate zones was isotopically depleted (Clark and Fritz, 1997). Groundwater samples collected from some upper Kittitas County wells appeared to be isotopically depleted compared to groundwater samples collected from upper Kittitas County springs suggesting that the isotopically depleted character could be related to variations in the timing of recharge. The isotopically depleted groundwater samples tended to be from deep or downgradient locations. Two of the sites with some of the most isotopically depleted groundwater (sites 5 and 6) appear, on the basis of ${ }^{14} \mathrm{C}$ data, to contain at least components of Pleistocene recharge. An alternative explanation for the presence of isotopically depleted groundwater could be based on a conceptual model in which isotopically depleted recharge from high-elevation zones constitutes the origin of isotopically depleted groundwater. This explanation is a common one in many groundwater basins, and arises from observations that stable isotopes of water can become increasingly depleted with increasing elevation. This effect is a physical manifestation of the rainout effect, and is commonly observed in basins where moisture masses drop precipitation while migrating away from moisture sources and up in altitude. These effects of elevation were not noted in the upper Kittitas County study area, as evidenced by precipitation and stream data. The rainout effect is reflected in the stable isotope data, but the isotopic fractionation associated with rainout occurs from west (enriched) to east (depleted), and the most isotopically enriched water is in the westernmost (highest elevation) zones. No modern water sources in the upper Kittitas County study area are sufficiently depleted in ${ }^{18} \mathrm{O}$ to account for the presence of the isotopically depleted groundwater at sites such as sites 5 and 6 , and Pleistocene recharge appears to be the source of the depleted $\delta^{18} \mathrm{O}$ values.

Two reasons for sampling selected sites for $\mathrm{SF}_{6}$ and ${ }^{14} \mathrm{C}$ were to provide constraints on groundwater residence time and complement $\delta^{18} \mathrm{O}$ and ${ }^{3} \mathrm{H}$ data in the upper Kittitas County study area. Sulfur hexafluoride data indicate that young, upgradient groundwater can have residence times on the order of years or less. These data are consistent with the stable isotope and ${ }^{3} \mathrm{H}$ data that indicate the presence of a groundwater system that can be highly dynamic in places, such as some shallow fractured rock settings. Environmental tracer data also indicate that some deep zones may have hydraulic connections that operate on long timescales, as evidenced by ${ }^{14} \mathrm{C}$ and $\delta^{18} \mathrm{O}$ data indicating the presence of Pleistocene water. Carbon-14 data help to constrain the origin of isotopically light groundwater and thus contribute to a more complete understanding of the spatial variability in stable isotope data. Stable isotope data are consistent with a strong degree of connectivity between shallow groundwater (represented by springs and most wells) and streams, and indicate that the most isotopically depleted groundwater (some deep wells in downgradient zones) is not a major component of stream water, although the location of isotopically light groundwater at depths in downgradient and near-stream environments presents a physical mass-balance condition in which removal of that groundwater can be expected to shift hydraulic gradients in a manner that does directly affect streamflow. Effective management of groundwater resources in the upper Kittitas County study area could benefit from the understanding that different parcels of groundwater can have different sources and be associated with a large range in residence times that may affect the degree to and timing over which these distinct groundwater parcels respond to management actions.

\section{Groundwater and Surface-Water Interactions}

Groundwater and surface-water interactions in the upper Kittitas County study area were characterized in 2011 and 2012 by a set of synoptic streamflow measurements termed a seepage run and by longitudinal temperature sensing at ambient streamflow velocity. The location and magnitude of groundwater gains and losses is apparent from seepage gains and losses measured during the seepage run. In two streams, the location of potential groundwater gains is additionally refined to relatively discrete stream reaches by using temperature as a tracer of groundwater inflow.

\section{Seepage Run}

Streamflow gains and losses were calculated for 19 seepage reaches (table 4). Gains in streamflow from groundwater were measured at nine seepage reaches, losses in streamflow to groundwater were measured at five seepage reaches, and near-neutral conditions were measured at five seepage reaches. The magnitudes of gains and losses ranged from approximately 100 percent of streamflow at Spex Arth Creek to near-neutral conditions at seepage reaches of Teanaway River, North Fork Teanaway River, Jack Creek, and Swauk Creek. Consistent with these near-neutral seepage results for the lower Teanaway and Swauk Rivers, Magirl and others (2009) reported synoptic streamflow measurements suggesting near-neutral conditions for the lower $3.6 \mathrm{mi}$ of the Teanaway River in September 2003 and the lower $5.9 \mathrm{mi}$ of the Swauk River in June and July 2005. Patterns of streamflow gains and losses were spatially variable (fig. 17). The dominance of gaining reaches reflects the nature of this hydrologic system - a system in which the aquifers receive recharge from precipitation and transmit that water to streams, which in turn serve as drains for the groundwater system. The seepage run also revealed several losses of streamflow where streams exit bedrock uplands and flow over unconsolidated sediments in the southern part of the study area (fig. 17). 


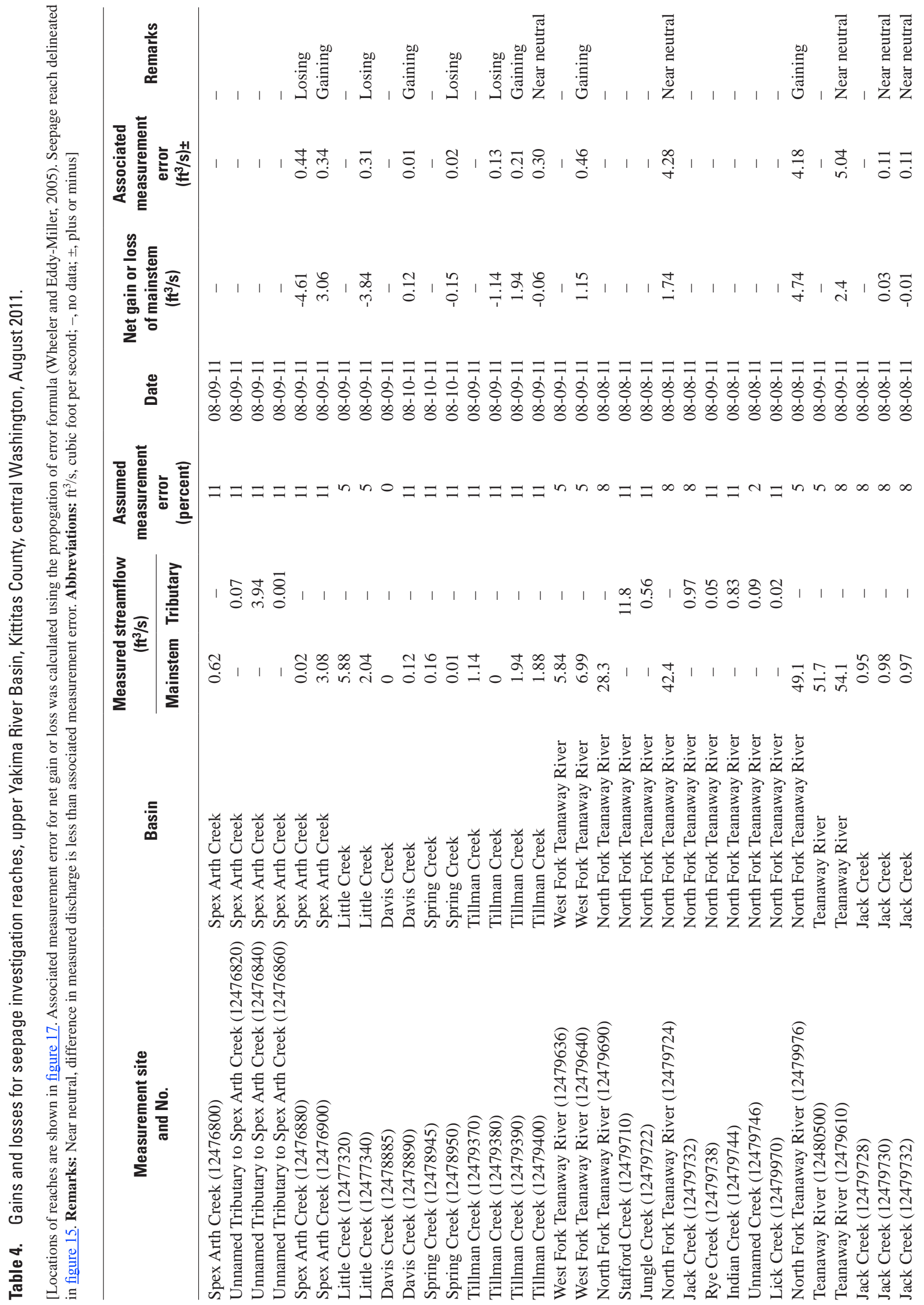




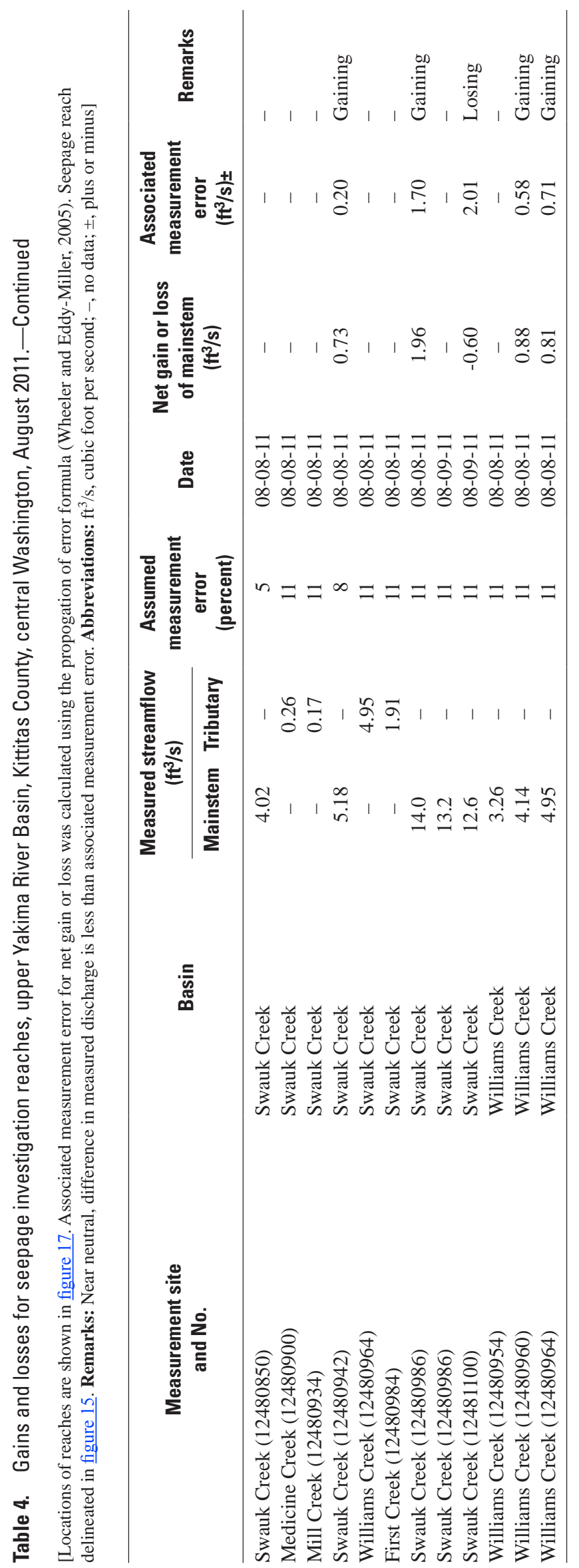




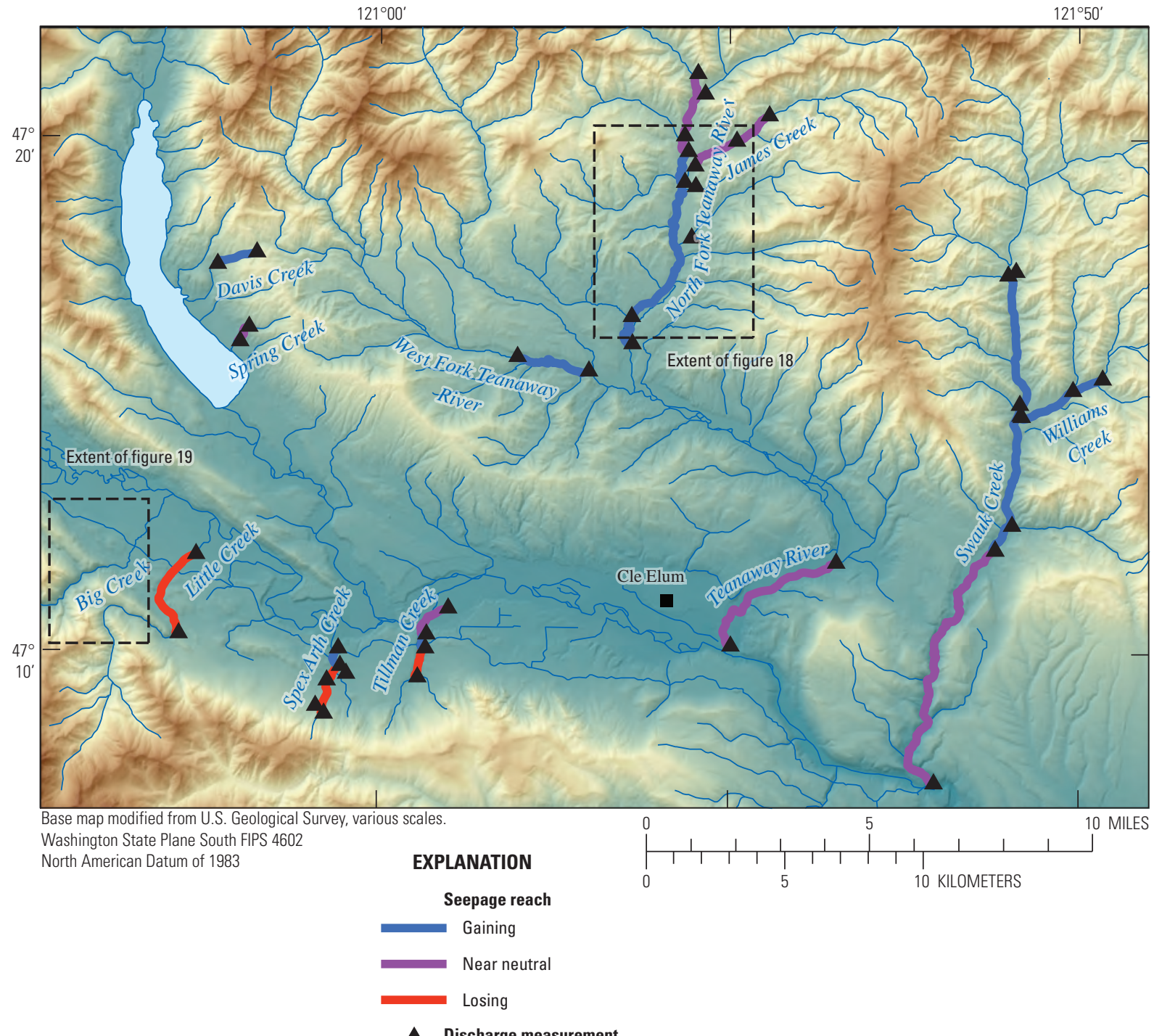

Figure 17. Gaining, near-neutral, and losing reaches measured during August 2011 seepage run, upper Yakima River Basin, Kittitas County, central Washington. 


\section{Longitudinal Thermal Profiling at Ambient Stream Velocity}

Several zones of potential groundwater recharge were delineated from the longitudinal temperature profiles of stream temperature measured at the North Fork Teanaway River (fig. 18) and Big Creek (fig. 19). Two zones of potential groundwater input were apparent from the longitudinal temperature profile measured in the North Fork Teanaway River (reaches A and B; figs. 18 and 20). The North Fork Teanaway River along the profiled reach was contained within a broad alluvial valley into which several small tributary streams entered. Groundwater gains were measured during the 2011 seepage run in the temperature profile reach of the North Fork Teanaway River. The Big Creek longitudinal temperature profile began in a bedrock-confined reach that was thinly covered with alluvium where temperature was relatively

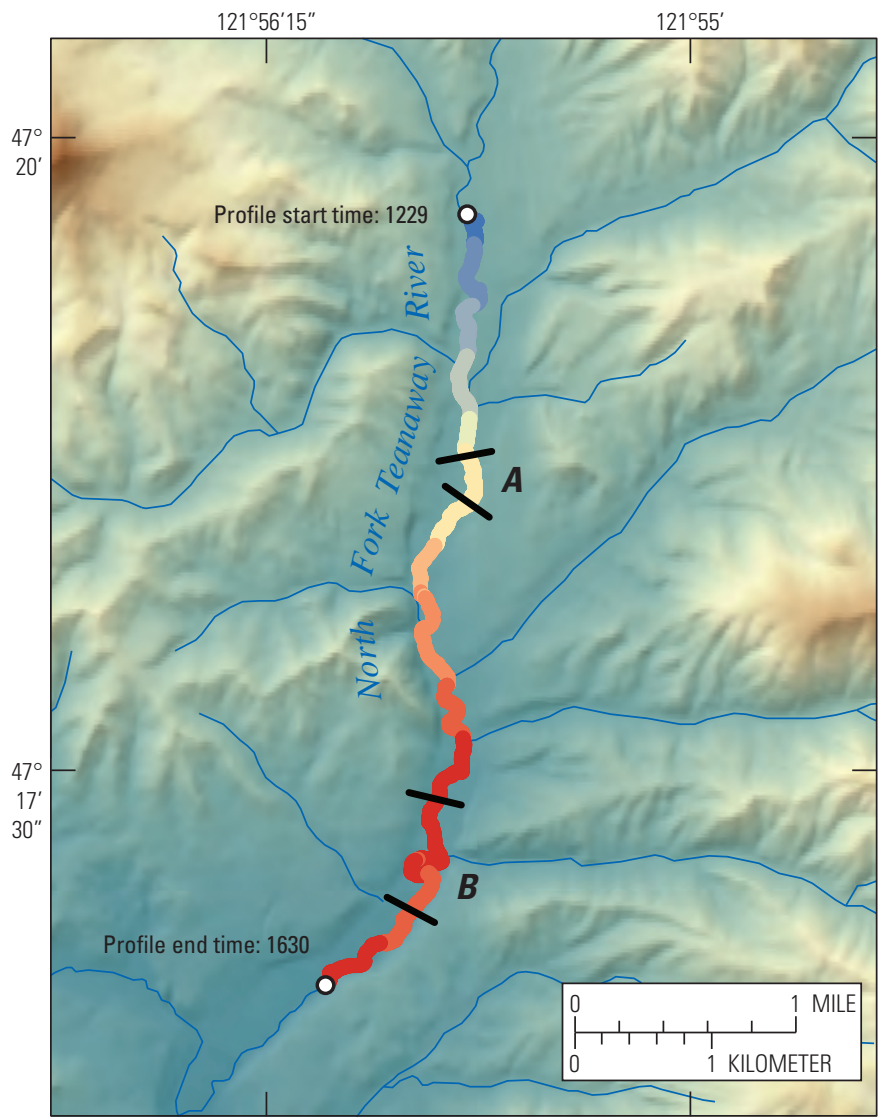

Base map modified from U.S. Geological Survey, various scales. Washington State Plane South FIPS 4602 North American Datum of 1983

\section{EXPLANATION}

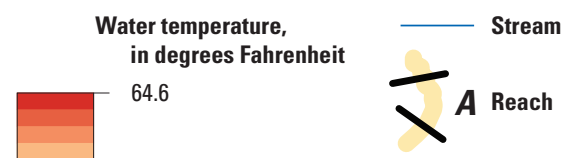

Figure 18. Longitudinal temperature profile at 54.7 North Fork Teanaway River on September 6, 2012, upper Yakima River Basin, Kittitas County, central Washington. Reaches $A$ and $B$ depart from the diurnal warming. constant (reach A; figs. 19 and 21). Reach A was well-shaded by a mature tree canopy and therefore did not receive high amounts of solar radiation. Slowly rising temperatures measured within this reach cannot be conclusively tied to groundwater inflow, but might be the result of reduced solar radiation. Downstream of reach A, Big Creek emerges from the mountain front into a broad alluvial fan with more limited tree cover, and the longitudinal temperature profile increases rapidly. Streams that emerge from a mountain front into an alluvial fan typically lose streamflow to the subsurface, which locally elevates the water table and contributes to gains downstream and in the larger streams that occupy the main valley (Konrad, 2006). Although Big Creek was not included in the 2011 seepage run, two zones of stabilizing temperature (reaches $\mathrm{B}$ and $\mathrm{C}$ ) were measured farther downstream suggesting that cold groundwater inputs were entering Big Creek along these reaches.

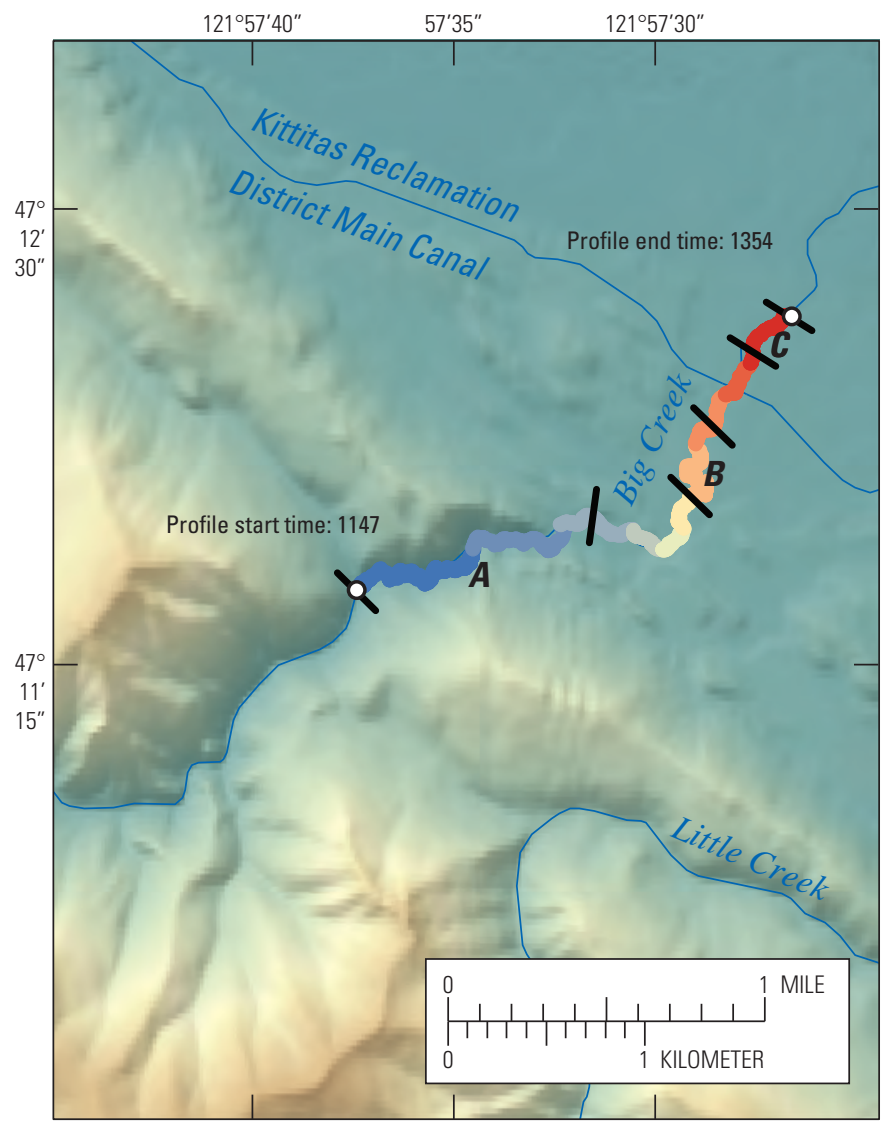

Base map modified from U.S. Geological Survey, various scales. Washington State Plane South FIPS 4602 North American Datum of 1983

EXPLANATION

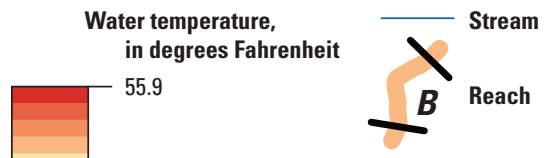

Figure 19. Longitudinal temperature profile at Big Creek on September 7, 2012, upper Yakima River Basin, Kittitas County, central Washington. Reaches A, $B$, and $C$ depart from diurnal warming. 


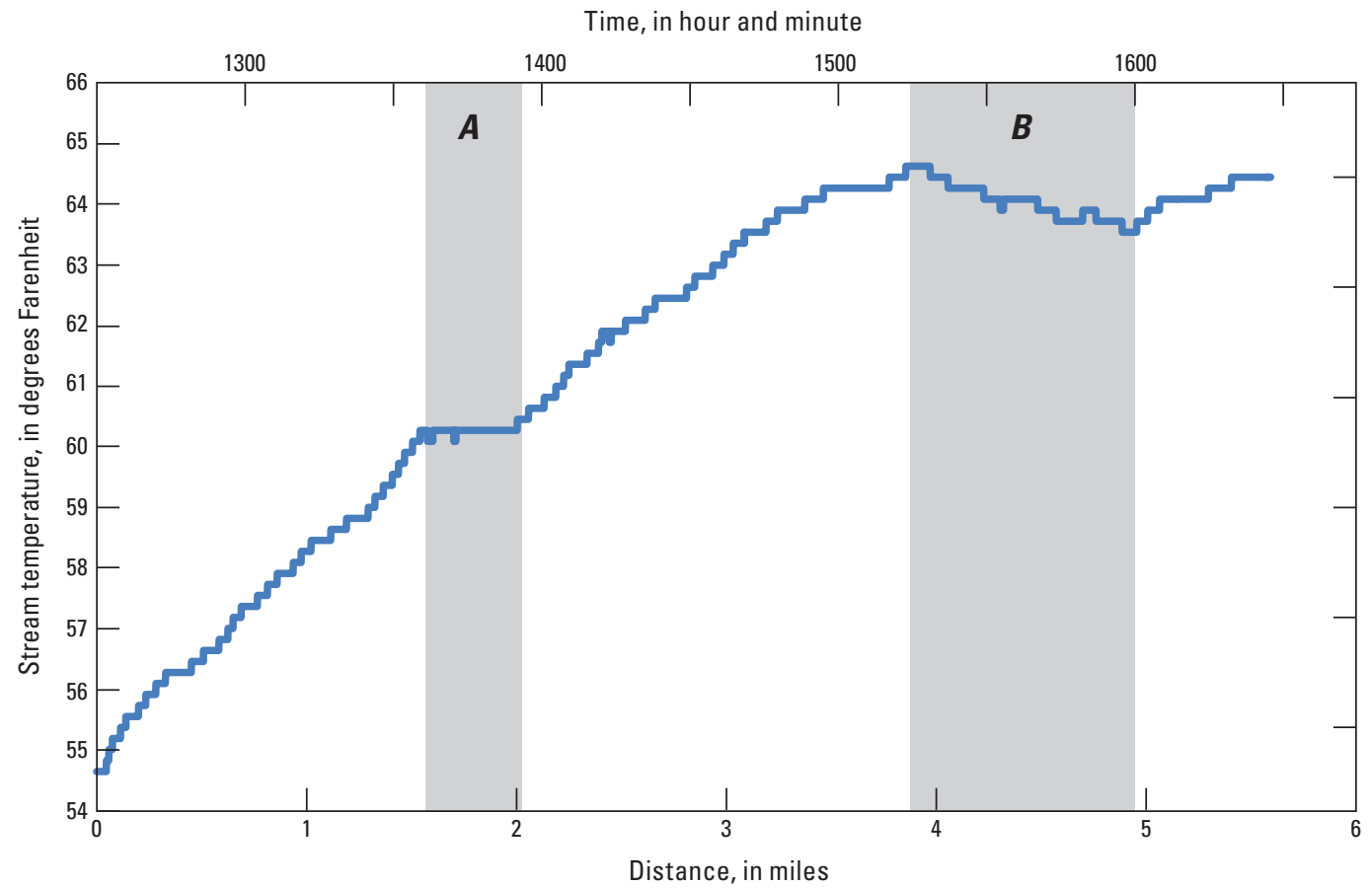

Figure 20. Longitudinal temperature profile at ambient flow velocity at North Fork Teanaway River on September 6, 2012, Yakima River Basin, Kittitas County, central Washington. Zones of departure from diurnal heating $A$ and $B$ are shown in gray.

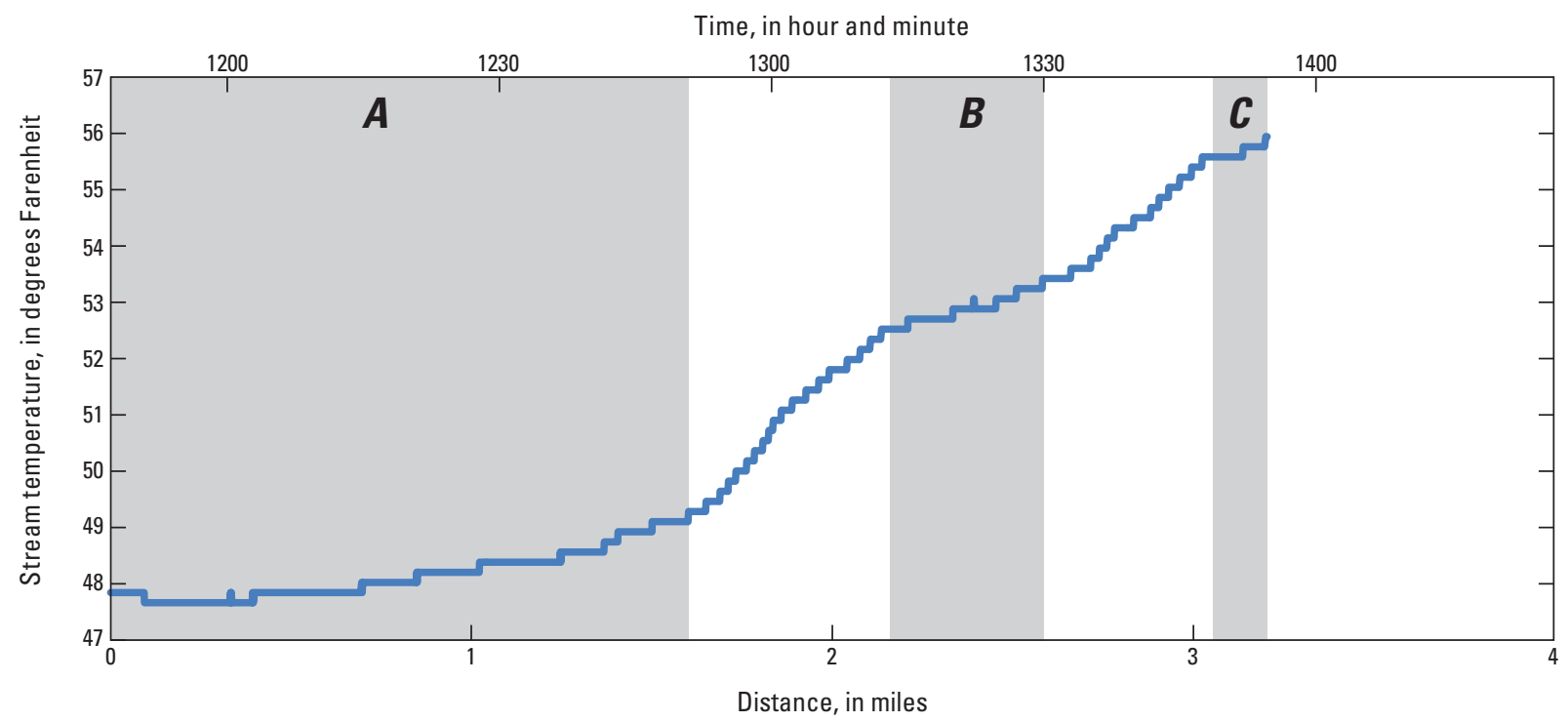

Figure 21. Longitudinal temperature profile at ambient flow velocity at Big Creek on September 7, 2012, Kittitas County, central Washington. Zones of departure from diurnal heating $A, B$, and $C$ are shown in gray. 


\section{Groundwater in Upper Kittitas County}

Groundwater in upper Kittitas County is derived from rainfall and snowmelt that percolates from the surface into sediment and rock. Topography, geologic structure, and the hydraulic characteristics of the aquifers control the general movement of groundwater. Groundwater generally flows from humid upland areas underlain by bedrock in the northern and western parts to sedimentary basins in the lowlands.

\section{Groundwater Occurrence and Flow System}

In upper Kittitas County, groundwater occurs under unconfined and confined conditions within aquifers comprised of unconsolidated sediments and bedrock. Bedrock hydrogeologic units include the basalt unit, the volcanic unit, the sediment unit, the metamorphic unit, and the intrusive unit (table 2). In many of the bedrock hydrogeologic units, primary porosity within the interstitial spaces between grains is low relative to fractures and other sources of secondary porosity. Conversely, primary porosity in the unconsolidated sediments is high relative to much of the bedrock aquifers resulting in a different type of groundwater-flow system within the unconsolidated sediment unit.

The bedrock hydrogeologic units are comprised of a diverse suite of rock types with varying hydraulic characteristics and amounts of primary and secondary porosity. The primary porosity of bedrock hydrogeologic units comprised of crystalline rocks including intrusive, metamorphic, volcanic, and basalt units is limited and does not contribute substantively to the availability of water within these units. In the coarse-grained strata in the sediment unit, however, enough groundwater occurs and moves through interconnected interstitial spaces to locally support some groundwater withdrawals (Vaccaro and others, 2009). In all types of bedrock units in the study area, fractures provide an important source of porosity, and the degree of their interconnection determines their permeability and ability to support withdrawals. Secondary porosity in interflow zones in flood basalts resulting from vesicles, breccia, and, if extruded into water, lava pillows contribute to high yield layers in the basalt unit. In these zones, groundwater flow is likely predominantly parallel to the structural gradient/ dip of the basalt (Vaccaro and others, 2009). These zones are separated from each other by dense and massive interflow zones with low hydraulic conductivity. Although related to the sedimentary and structural template of the study area, the fracture system within the bedrock aquifers including the number, size, and extent of interconnection is highly complex resulting in highly variable occurrence of groundwater and largely unknown flow paths, particularly at a local scale. Thus, it is not feasible to determine groundwater flow directions in the bedrock hydrogeologic units.
In the unconsolidated sediment unit, groundwater occurs and moves through the interconnected pore spaces (interstices) between particles. Coarse-grained sediments with high hydraulic conductivity (including alluvium and glacial outwash) comprise the major water-bearing units within the unconsolidated sediment unit. Groundwater occurs under unconfined conditions where these sediments are not overlain by a confining unit comprised of glaciolacustrine sediment, till, and other sediments with low hydraulic conductivity. Groundwater occurs under confined conditions beneath the confining unit, which occurs discontinuously throughout the extent of the unconsolidated sediment unit.

A water-level map was developed for the unconfined part of the unconsolidated sediment unit using water levels measured in wells open in the unconsolidated sediment unit to estimate directions of horizontal groundwater flow (fig. 22). Contours of equal water-level altitude for wells open to the unconsolidated sediment unit were drawn at $50-\mathrm{ft}$ intervals by interpolating between point measurements of water level collected between April and May 2011, topographic contours, and the altitudes of stream-surfaces. Groundwater in the study area flows within the unconsolidated sediment unit and generally follows the topography and surface-water drainage of the study area. Groundwater typically discharges into the Yakima River and its tributaries and does not move through the subsurface at the outlet of the study area (Vaccaro and others, 2009).

\section{Effects of Fractures on Groundwater Flow}

The complexity and size of the fracture-flow system of bedrock aquifers in upper Kittitas County precluded their explicit characterization during this study. Studies of fractured bedrock aquifers at other locations where smaller study areas permitted more detailed observations (for example, Shapiro and others, 2007), however, provide information about the characteristics and dynamics of flow through fractured bedrock aquifers that is applicable to the study area. The hydraulic properties of fractured-bedrock aquifers vary considerably over spatial scales resulting in complex groundwater-flow systems in these aquifers. For example, Shapiro and others (2007) determined that fractures in a fractured bedrock aquifer around Mirror Lake in central New Hampshire varied in hydraulic conductivity by six orders of magnitude. Despite highly transmissive fractures measured over small spatial scales, the bulk hydraulic conductivity on scales of $1,000 \mathrm{ft}$ to several $\mathrm{mi}$ was the same as the less transmissive fractures observed at small spatial scales (ig. 23 ). These less transmissive fractures acted as "bottlenecks" that impeded groundwater flow through the fractured bedrock aquifer (Shapiro and others, 2007). Thus, although high yield wells exist within the fractured bedrock aquifers of the upper Kittitas County study area, hydraulic properties suggested by these yields ultimately could be limited by less transmissive fractures that control the transmissivity of the overall groundwater-flow system. 

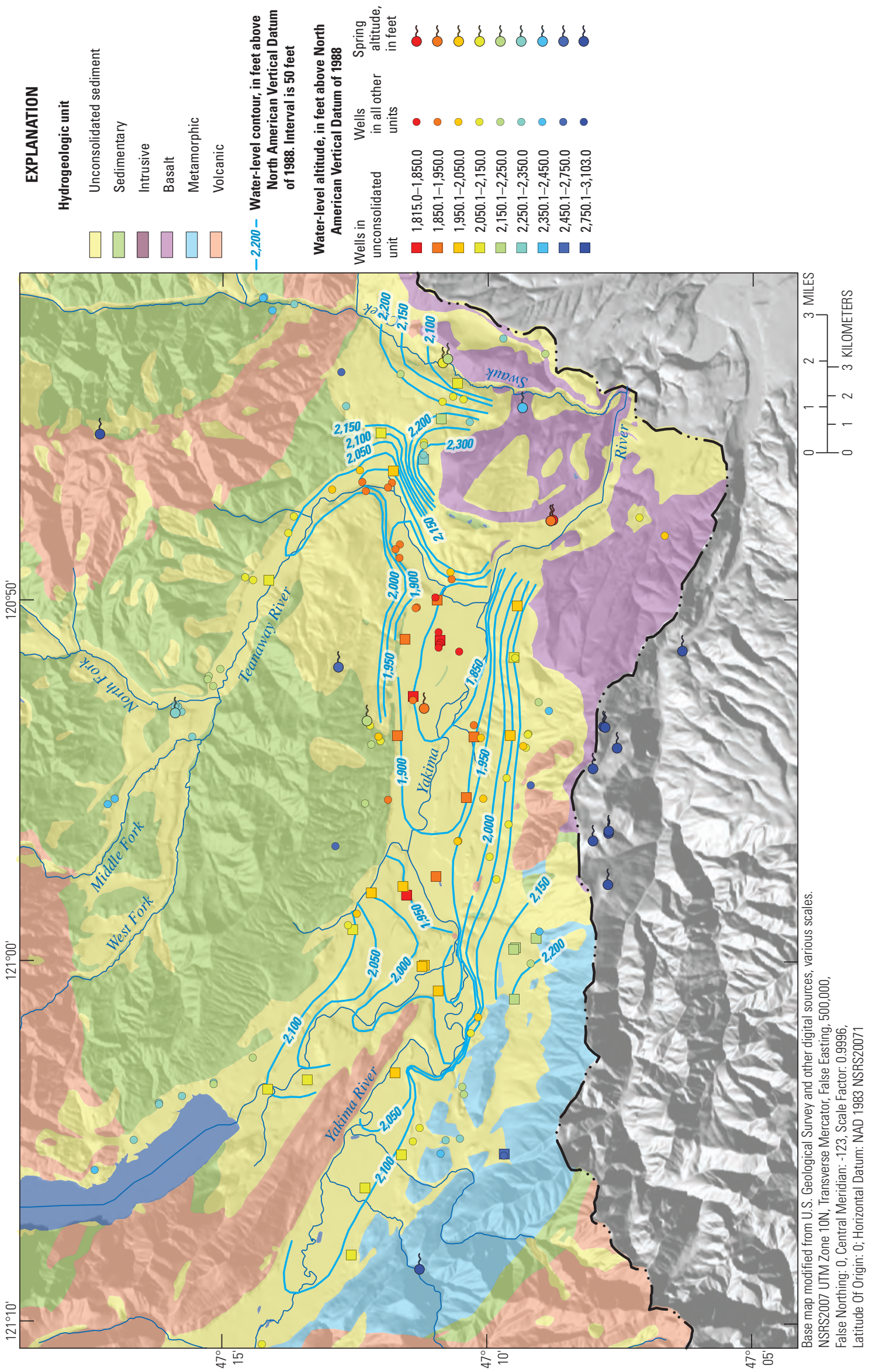

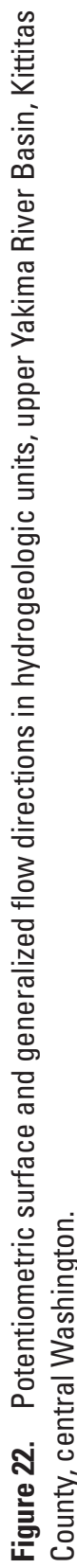




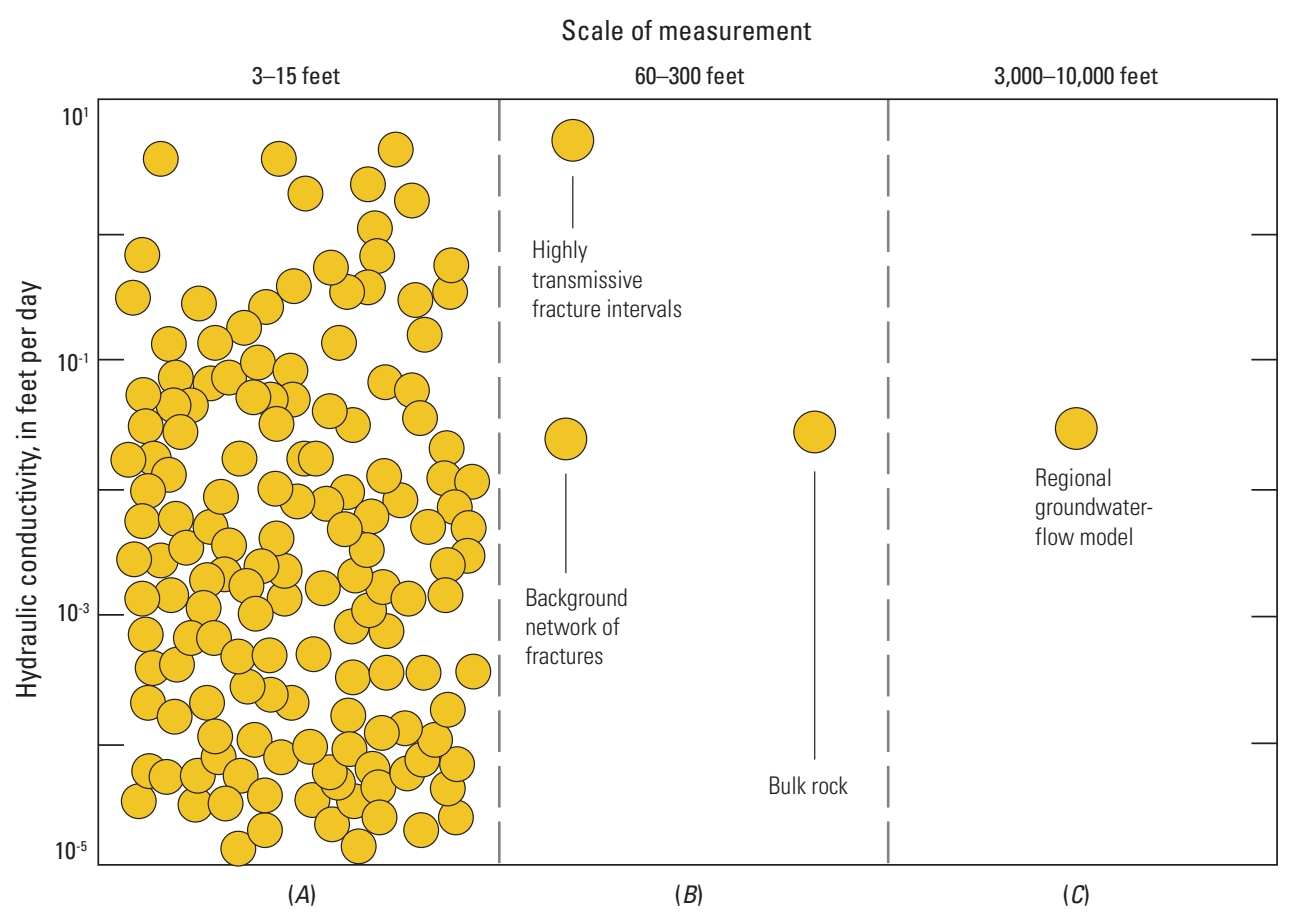

Figure 23. Hydraulic conductivity in fractured bedrock as estimated over increasingly larger physical dimensions from $(A)$ discrete-interval, single hole hydraulic tests, $(B)$ cross-hole hydraulic tests, and $(C)$ regional groundwater-flow models, Mirror Lake watershed and vicinity, New Hampshire. Modified from Shapiro and others, 2007.

At a local scale, the degree of inter-connection between transmissive fractures influences groundwater levels in adjacent wells differently than an aquifer where hydraulic properties are more homogenous. In a homogenous aquifer, drawdown diminishes with distance from the pumped well, but Hsieh and Shapiro (1996) and Hsieh and others (1999) hypothesize that the drawdown responses in fractured bedrock aquifer are determined by the spatial connectivity of high transmissivity fractures. Shapiro and others (2007) show that in intervals of wells connected through highly transmissive fractures (for example, 1B, 4B, and 5 in fig. 24), the drawdown response is similar and has no relation to distance. This is the result of the rapid fluid pressure response through the highly transmissive fracture zone that connects the wells. Other interconnected intervals (for example, 1A and 4A) show a similar drawdown response to each other, but because they are connected only by low-transmissivity fractures to the fracture system connecting $1 \mathrm{~B}, 4 \mathrm{~B}$, and 5 (fig. 24), the intervals have their own distinct drawdown response. These data suggest that over small spatial scales, variability in the hydraulic properties of different fracture systems and the degree to which fracture systems are interconnected can cause some wells to respond quickly to drawdown in adjacent wells where well intervals are closely connected by high transmissivity fractures. Drawdown responses may be independent where wells are hydraulically isolated by low-transmissivity fractures. In the upper Kittitas County study area, many wells within fractured bedrock aquifers are open over hundreds of feet and may be open to multiple high-transmissivity fractures to obtain sufficient well yields, which further complicates the relation between water levels in adjacent wells. The relation of the fracture flow system to areas receiving recharge also plays a critical role in groundwater dynamics within fractured bedrock aquifers. In homogenous aquifers, the effect of recharge on water-level fluctuations attenuates with depth; however, where high-transmissivity fractures are connected to zones near the surface receiving recharge, amplitudes in water-level fluctuations resulting from recharge may be more pronounced. 


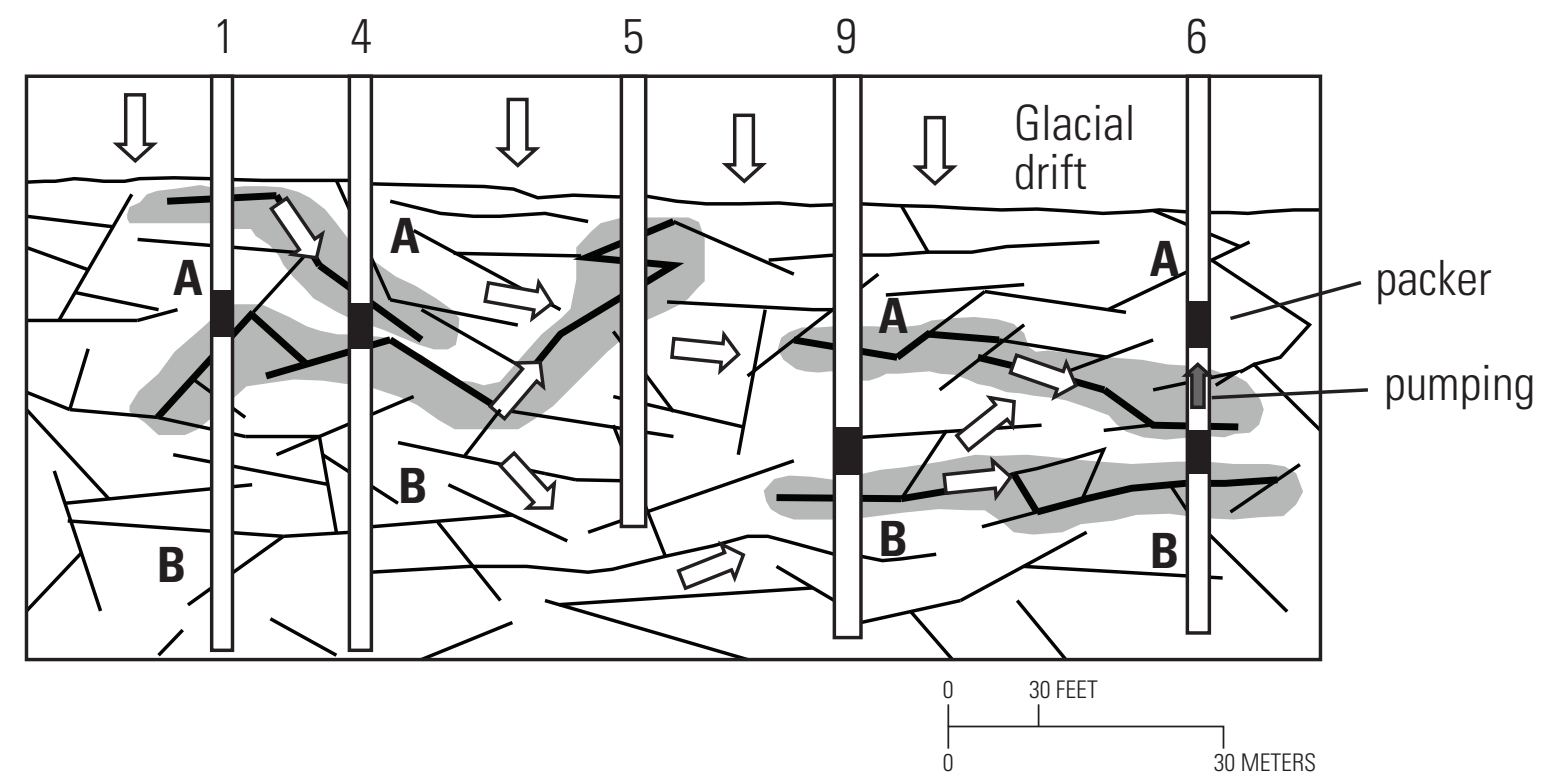

Figure 24. Hypothesized distribution of fractures having high transmissivity (depicted by zones of gray) in the rock underlying the well field; the intervals of high-transmissivity fractures are connected only by less transmissive fractures. Numbers refer to wells. Modified from Shapiro and others, 2007.

\section{Groundwater-Level Fluctuations}

Water levels in wells in the study area fluctuate as a result of changes in the rates of recharge to and discharge from the aquifer system, which can vary annually and seasonally as a result of temporal variability in precipitation and human activities like irrigation and well pumpage. Water levels rise and the amount of water stored in the aquifer increases when recharge exceeds discharge; conversely, when discharge exceeds recharge, water levels decline and water storage decreases. In the study area, recharge to and discharge from the aquifer system are not distributed evenly throughout the year. This results in general increases in water levels and storage during the late autumn through spring when most of the annual recharge from rainfall and snowmelt occur. In the summer and early autumn, when recharge from precipitation is lowest and withdrawals from wells are highest, water levels generally decline. For example, the water level in well 20N/16E-30C01, which is completed at a depth of $160 \mathrm{ft}$ in the sediment unit, was highest in May and lowest in September (fig. 25A), which is typical of wells throughout the study area. However, in wells that are hydraulically connected to surface-water features, such as canals, rivers, and reservoirs that are used for irrigation, there are notable exceptions to this seasonal hydrograph. These include well 19N/15E-08B02, which is completed at a depth of $105 \mathrm{ft}$ in the unconsolidated sediment unit, where the water level reached its highest point in August 2012 coincident with the largest flows in the KRD irrigation canal and reached its lowest level in April 2013 after months of no irrigation (fig. 25B).

Typically, shallow wells have larger fluctuations in water levels and respond more quickly to changes in recharge than deep wells because shallow wells are closer to the source of recharge. The largest seasonal water-level fluctuations in the study area, however, occurred in deep wells completed within bedrock aquifers where flow and storage are controlled by fractures. In the volcanic unit, for example, water levels fluctuated between about 6 and $48 \mathrm{ft}$ in wells with a median depth of $370 \mathrm{ft}$, whereas water levels fluctuated between about 0.7 and $10 \mathrm{ft}$ in the unconsolidated sediment unit (table 5). The presence of water-bearing fractures with high hydraulic conductivity, but low storage capacity in recharge areas and the relatively low storage capacity of cemented sediments and crystalline rocks may contribute to unexpectedly large water fluctuations within fractured bedrock aquifers (Freeze and Cherry, 1979; Fetter, 1988). 


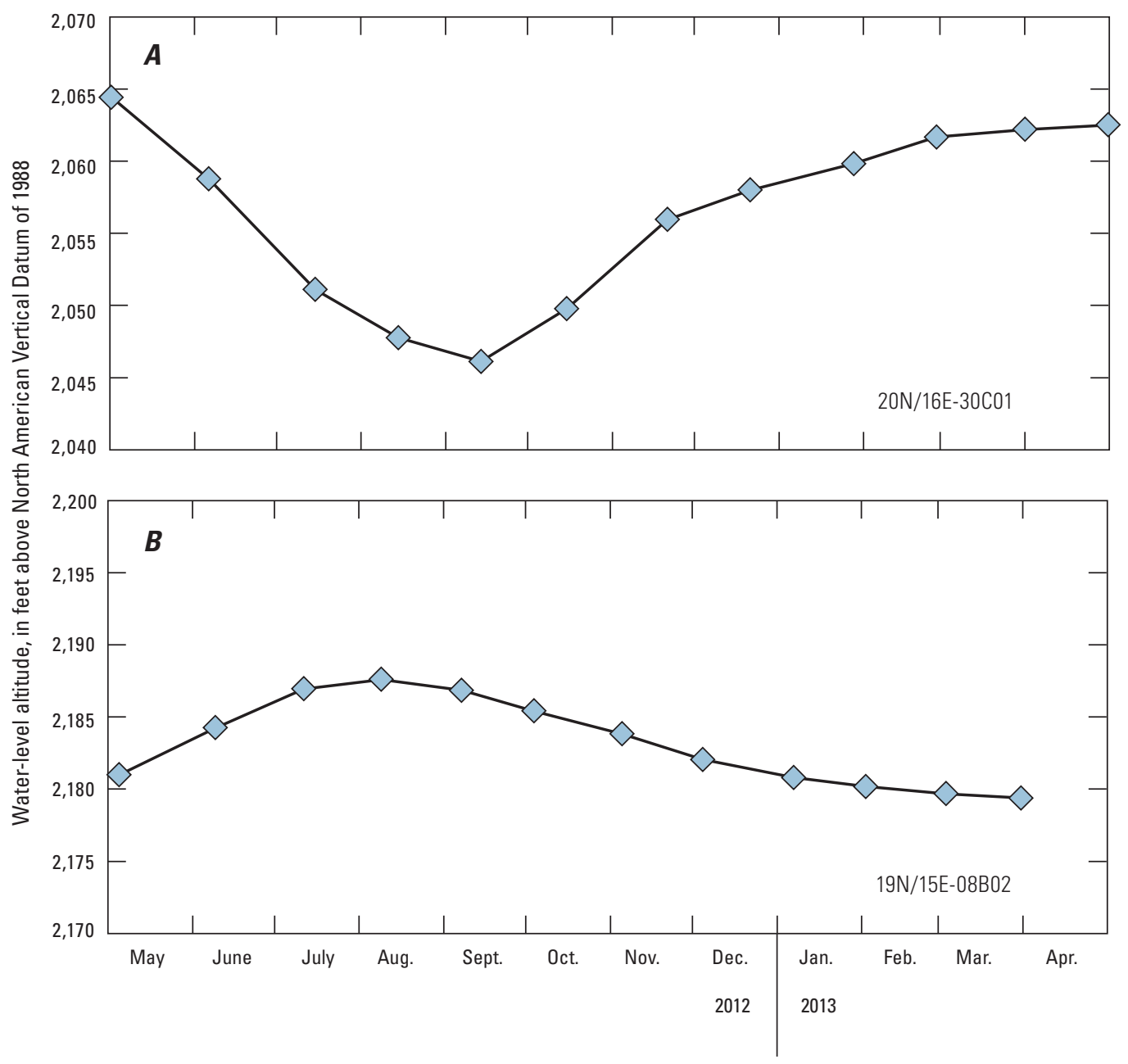

Figure 25. Water levels in wells $(A)$ 20N/16E-30C01 and $(B)$ 19N/15E-08B02, upper Yakima River Basin, Kittitas County, central Washington, May 2012-April 2013.

Table 5. Statistical summary of water-level fluctuations and well depth by hydrogeologic unit, upper Yakima River Basin, Kittitas County, central Washington, May 2012-April 2013.

[Abbreviation: -, not available]

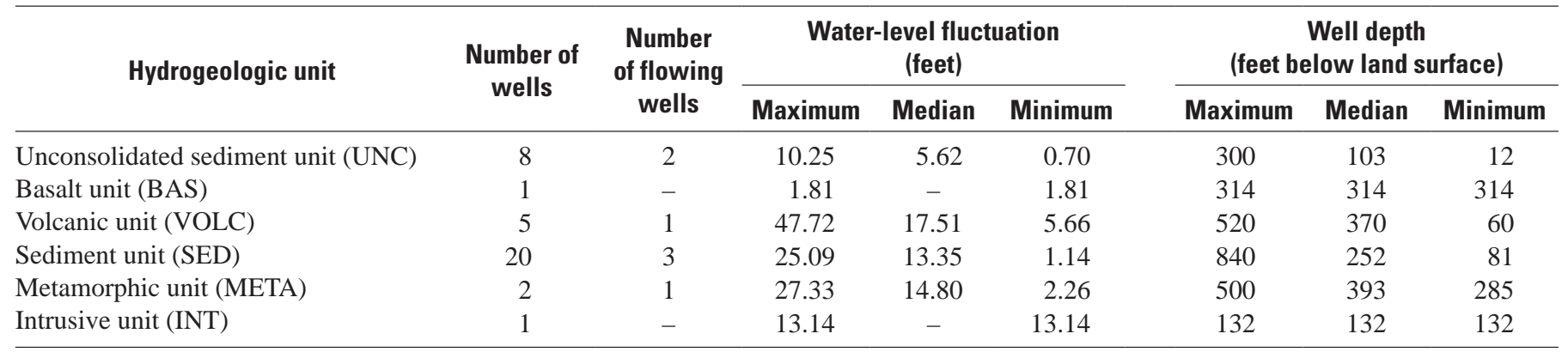




\section{Groundwater Use}

Groundwater pumping in the Yakima River Basin was estimated as part of the USGS Yakima River Basin groundwater study for eight categories of use for 1960-2001 (Vaccaro and Sumioka, 2006). The eight categories of pumping were public water supply (including wells for Group B, systems defined as supplies with less than 15 connections), self-supplied domestic (permit-exempt wells), irrigation, frost protection, livestock and dairy operations, industrial and commercial processes, fish and wildlife propagation, and groundwater claims. Pumpage estimates were based on methods that varied by the category and primarily represent pumpage associated with groundwater rights. Methods, pumpage estimates, reliability of the estimates, and a comparison with appropriated quantities are described by Vaccaro and Sumioka (2006) and Vaccaro and others (2009).

The pumping estimates described in Vaccaro and Sumioka (2006) and Ely and others (2011) for the entire Yakima River Basin can be used to provide estimates for the upper Kittitas County study area. Pumping rates for most categories remained fairly stable for the latter part of the period (1980-2001), as WaDOE largely ceased the approval of new groundwater rights. Groundwater pumping for hatcheries increased significantly in the late 1990s because of an expansion of hatchery operations in Cle Elum, but it should be noted that these withdrawals are not consumptive, as the groundwater is returned directly to the Yakima River. Domestic and public water supply withdrawals increased because of population growth and the potential effects of the withdrawals were a major source of concern. To better understand the effects of increased withdrawals, the estimates for permit-exempt (domestic) groundwater pumpage needed to be refined.

In Washington State, water users are required to apply for a water right permit from the WaDOE to withdraw groundwater unless they meet certain groundwater permit exemptions. Washington State Statute 90.44.050 (Washington State Department of Ecology, 2006) outlines these exemptions as:

- Providing water for livestock (no gallon per day limit).

- Watering a non-commercial lawn or garden one-half acre in size or less.

- Providing water for a single home or group of homes (limited to 5,000 gal/d).

- Providing water for industrial purposes, including irrigation (limited to 5,000 gal/d but no acre limit).

In order to evaluate permit-exempt well use in the upper Kittitas County study area, consistent and reproducible methods were required. Although small compared to the larger amount of water used for irrigation and public supply, self-supplied permit-exempt well groundwater pumpage is important to quantify. Because most exempt wells are not metered, methods to estimate the amount of water pumped from these wells were needed. Various sources were accessed to make these estimates, including public water supply information from the Washington State Department of Health (WaDOH, written commun., February 13, 2012), population data from the Washington State Office of Financial Management ( 2012) and water use/per capita rates from the Yakima River Basin (Vaccaro and Sumioka, 2006).

From 2000 to 2010, the population of Kittitas County increased by 22.6 percent, and the population of the study area increased by 19.6 percent (table 6). For comparison, the percent change for the State of Washington during the same period was 14.1 percent. The distribution of census blocks with a population greater than zero in 2010 are shown in figure 6. Due to an absence of data about seasonal population changes, the results presented herein are solely based on U.S. Census Bureau populations reported by the Washington State Office of Financial Management (2012) and population-served quantities reported by the public water supply systems.

From 2000 to 2010, the estimated full-time residential population served by public supply, Group A water systems in the study area increased from 5,300 to 5,711 (Ron Lane, U.S. Geological Survey, written commun., December 14, 2012). About 20 water suppliers serve this population, primarily in the more densely populated areas near Cle Elum. For 2010, the reported groundwater pumpage for the Group A public supply systems within the study area was estimated to be 1,017 acre-ft (0.91 million gallons per day [Mgal/d]) (Ron Lane, U.S. Geological Survey, written commun., December 14, 2012). Because of differences in reporting public supply usage from 2000 to 2010, no estimates for Group A pumpage for 2000 have been calculated. After subtracting the publicsupply population from the total population of the study area, the estimated self-supply population was 2,076 for 2000 and 3,109 for 2010. In 2000, the number of people using exempt wells was approximately 28 percent of the total study area population, and in 2010 that number increased to approximately 35 percent. The results of the dasymetric mapping show the spatial distribution of the self-supplied population after being redistributed to the residential land use (parcel) data (fig. 26). For self-supplied census blocks in the KRD, the population totals were multiplied by $109 \mathrm{gal} / \mathrm{d}$ to estimate daily groundwater pumpage from exempt wells. Outside the KRD, the daily per capita rate of $251 \mathrm{gal} / \mathrm{d}$ was used. Within the study area, the estimated annual pumpage in 2000 was 436 acre-ft (0.39 Mgal/d) and 699 acre-ft (0.62 Mgal/d) in 2010. Estimates of commercial/industrial and irrigation groundwater pumpage for the study area were based on published values for the entire Yakima River Basin (Vaccaro and Sumioka, 2006). In 2000, the estimated industrial/commercial groundwater use was 61 acre-feet/ year (0.05 Mgal/day) and $828 \mathrm{acre-ft/yr} \mathrm{(0.74} \mathrm{Mgal/d)}$ for irrigation. 


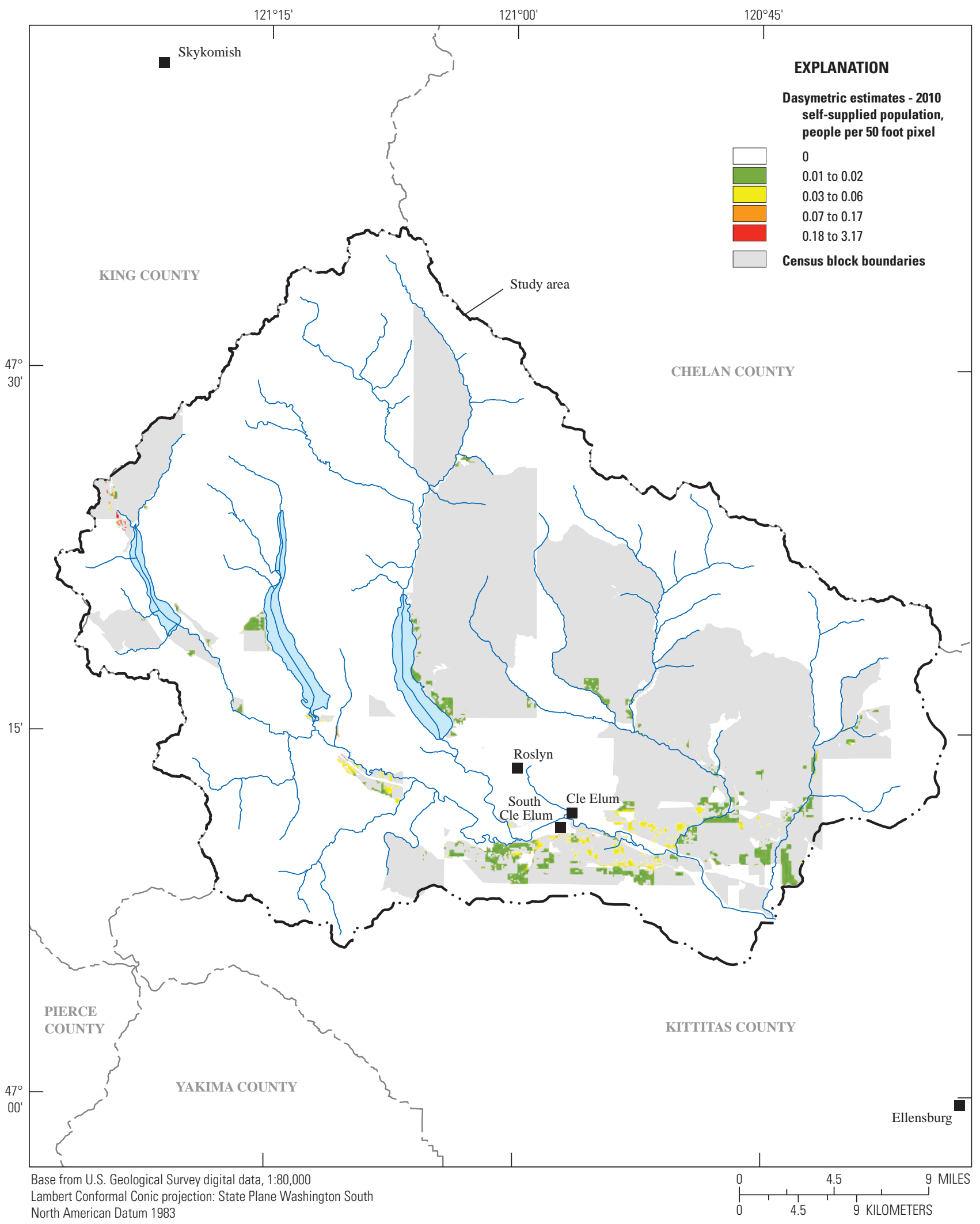

Figure 26. Dasymetric estimates of population using self-supplied (domestic private well) water for upper Yakima River Basin, Kittitas County, central Washington, 2010. 
Table 6. Population and estimated population served by public supply and domestic exempt wells, upper Yakima River Basin, Kittitas County, central Washington, 2000 and 2010.

\begin{tabular}{cccccc}
\hline \multirow{2}{*}{ Census year } & \multicolumn{2}{c}{ Population } & & \multicolumn{2}{c}{ Estimated population served by } \\
\cline { 2 - 3 } \cline { 5 - 6 } & Kittitas County & Study area & & Public supply wells & Exempt wells \\
\hline 2000 & 33,362 & 7,376 & & 5,300 & 2,076 \\
2010 & 40,915 & 8,820 & & 5,711 & 3,109 \\
\cline { 2 - 3 } \cline { 5 - 6 } Percent change & 22.6 & 19.6 & & 7.8 & 49.8 \\
\hline
\end{tabular}

\section{Water Budget for Upper Kittitas County and Selected Subbasins}

Water budgets provide a means for evaluating availability and sustainability of a water supply and a basis for assessing how a change in one part of the hydrologic cycle may affect other aspects of the cycle (Healy and others, 2007). For understanding groundwater in bedrock terrains, the most important factor is to understand a water balance (A. Shapiro, U.S. Geological Survey, written commun., January 10, 2008).

Although magnitudes of water-budget components vary across the study area, with simulated precipitation ranging from $110 \mathrm{in} / \mathrm{yr}$ in the Keehchelus Lake subbasin to $23 \mathrm{in} / \mathrm{yr}$ in the Horlick subbasin (fig. 7), the general patterns and distributions of the water budget exhibit similar characteristics (fig. 27A). Most water leaves the subbasins as runoff, with lesser amounts being evapotranspired.
Except for the Teanaway River and Horlick (which includes the lower Teanaway River) subbasins, roughly equal percentages of precipitation are evapotranspired or made available for recharge. In the PRMS models, almost all water designated as recharge returns to the streams as flow from the groundwater reservoir.

The monthly water budgets for all subbasins also exhibited similar patterns (fig. 27B). Precipitation falls mainly as rain and snow during November through March with little precipitation occurring in the summer months. Streamflow occurs later in the spring as snow melts and evapotranspiration occurs during the late spring and early summer when temperatures are warm but water is still available. The source of recharge in the PRMS models is predominantly either rainfall or snowmelt and occurs mostly from October through June. The PRMS model does not simulate the groundwater recharge that would occur from streamflow losses, because in basins such as the study area, such streamflow losses are eventually returned to streams. 


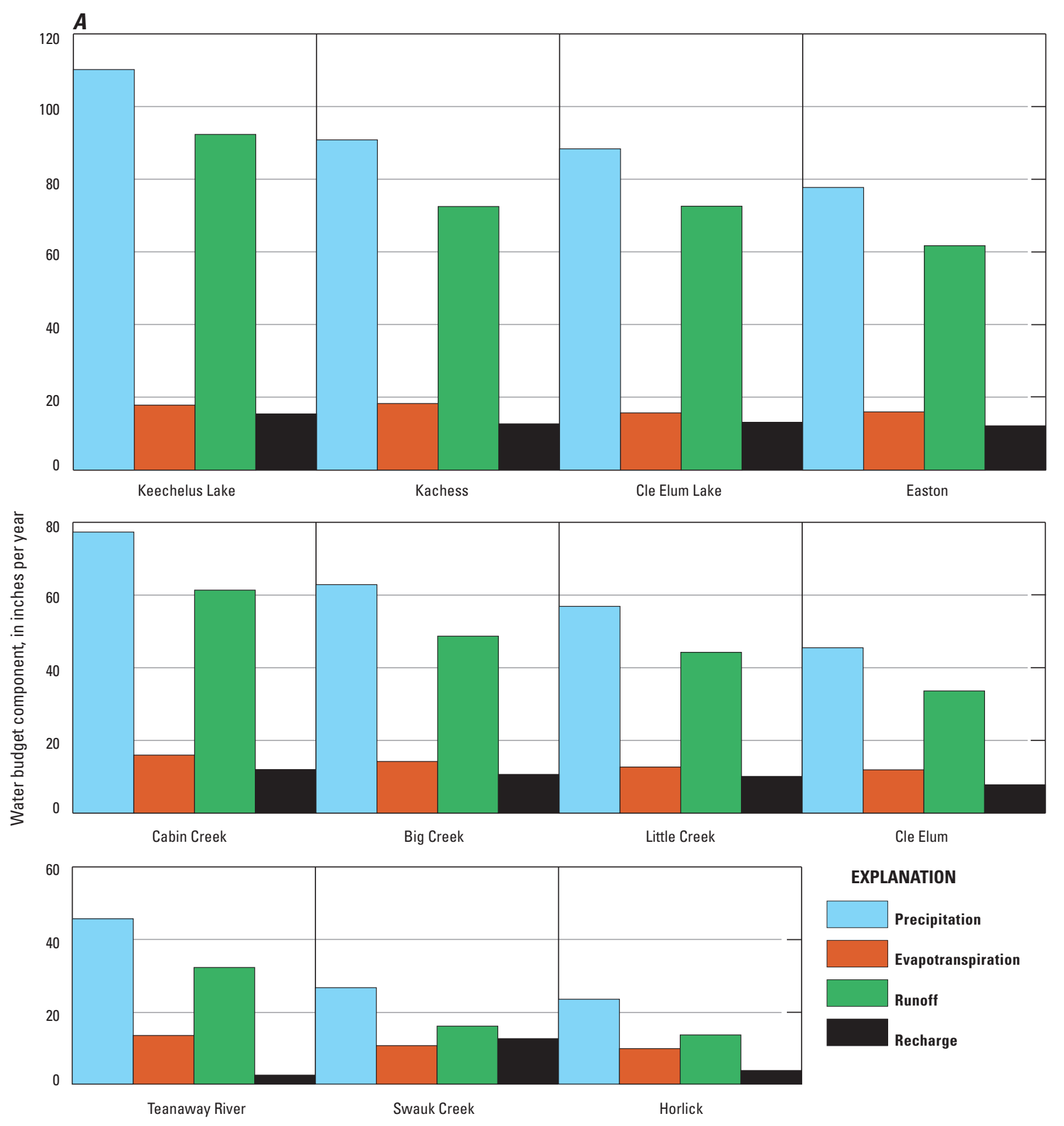

Figure 27. (A) Mean annual $(B)$ and mean monthly water budget components for modeled subbasins for upper Yakima River Basin, Kittitas County, central Washington. 


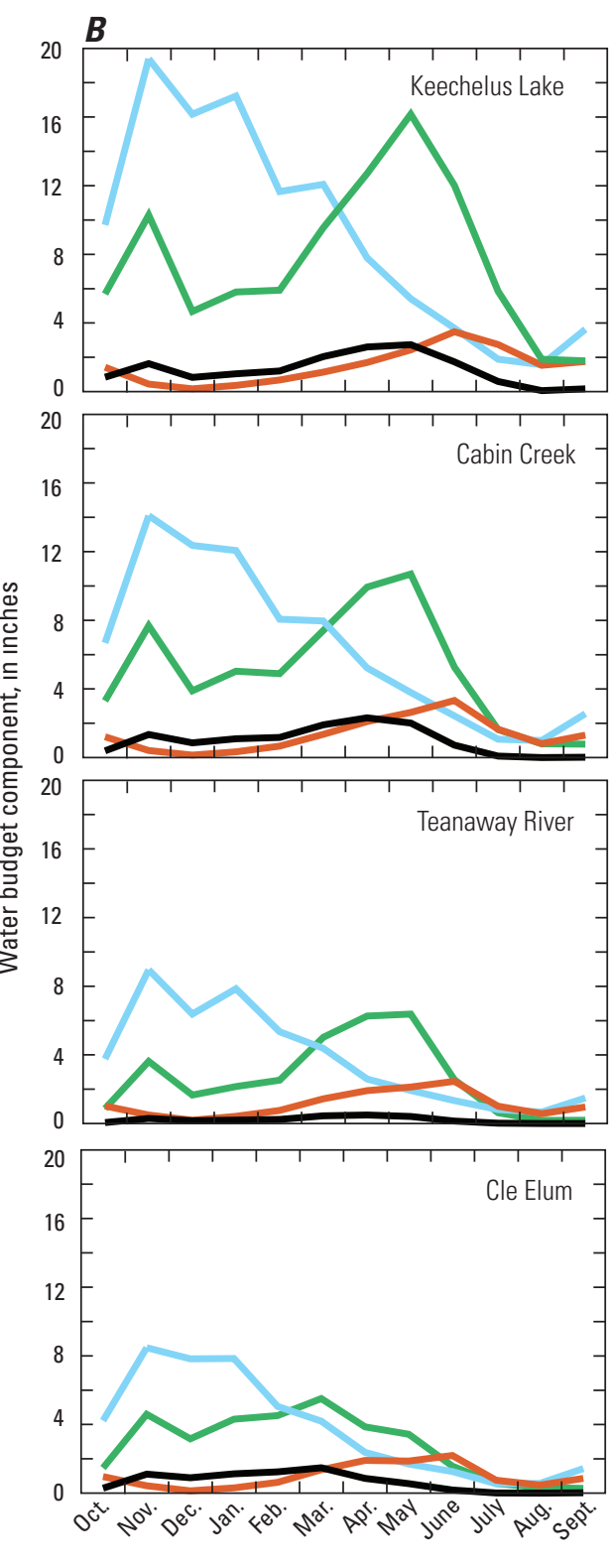

Month of water year
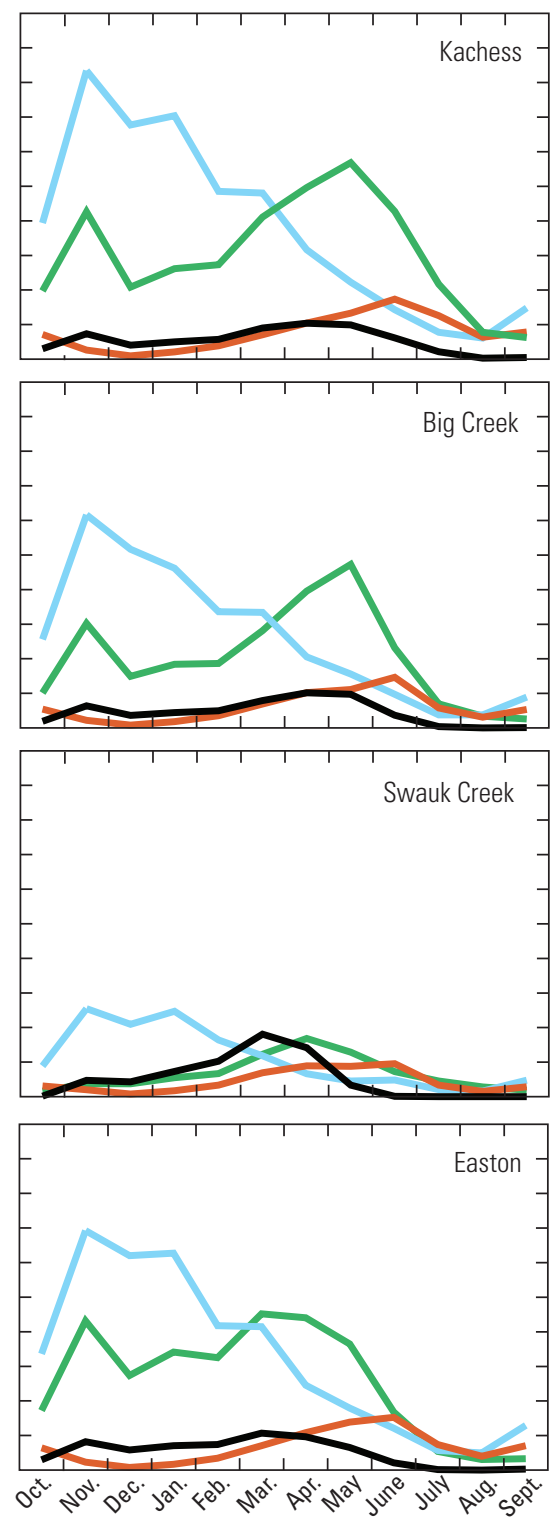

Month of water year
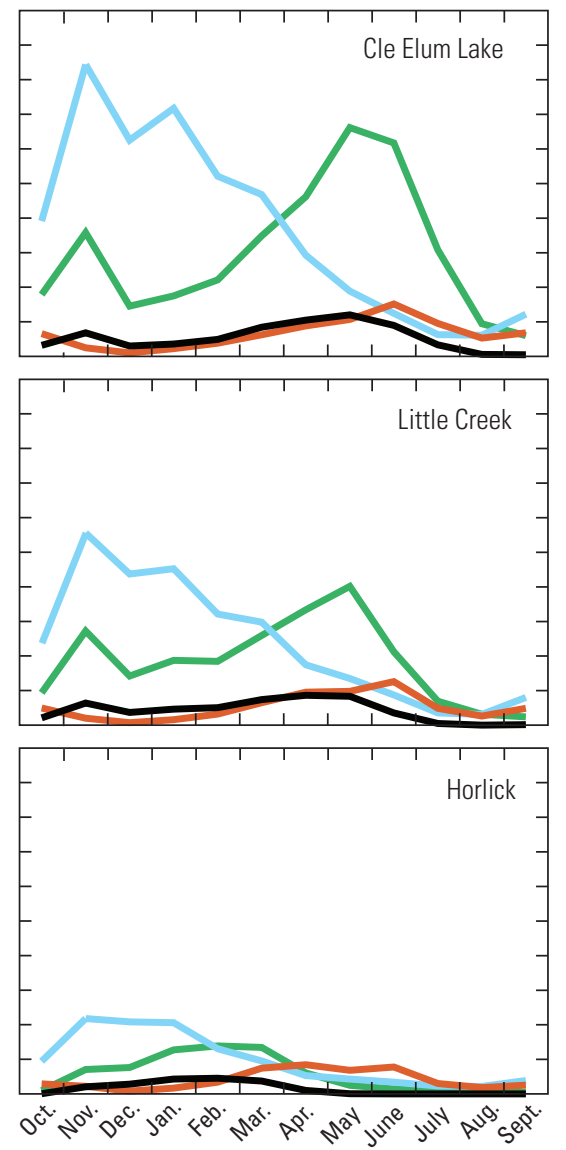

Month of water year

EXPLANATION

Precipitation

Evapotranspiration

Runoff

- Recharge

Figure 27.-Continued 


\section{Potential Effects of Groundwater Withdrawals on Surface-Water Features}

Groundwater moves continuously through aquifers from areas of groundwater recharge to areas of groundwater discharge (Barlow and Leake, 2012). In the upper Kittitas County study area, groundwater commonly discharges to streams, springs, lakes (reservoirs), and wells. Streams can be the primary location for groundwater discharge and groundwater is the main component of streamflow during the summer base flow period, as shown by the geochemistry analysis and seepage measurements conducted as part of this study. Where the altitude of an aquifer's potentiometric surface, or water table, is greater than the stream stage, the aquifer discharges groundwater into the stream resulting in a gaining stream; conversely, a stream loses water to the underlying aquifer if its stage is higher than the aquifer's water table. The rate of water exchange between a stream and adjoining aquifer depends, in part, on the hydraulic gradient between the aquifer and stream and the permeability of streambed sediments. In turn, the degree to which pumping draws down water levels in an aquifer will influence the magnitude and direction of exchange of water between aquifers and surface-water features. Because of their proximity to surface-water features like streams, pumping of wells in surficial unconfined aquifers pose a concern for depletion of streamflows; however, flow paths of water from deeper confined aquifers to surface-water features also exist, suggesting that pumpage within confined aquifers also may affect streamflows.

Groundwater discharge is a significant component of streamflow, and understanding the concepts relating to streamflow depletion from groundwater withdrawals is the subject of a comprehensive USGS report describing "the processes and factors that affect the timing, rates, and locations of streamflow depletion" (Barlow and Leake, 2012, p. 76). Basic principles of physics require that the volume of groundwater pumped and used consumptively must be offset by changes in flow to or from other sources (Theis, 1940). Groundwater withdrawn by wells initially comes from release of water from aquifer storage, but the withdrawal increasingly captures water, where captured water consists of either a reduction in the discharge to streams, springs, and other surface-water features, or an induction of discharge to the aquifer from the surface-water features. Both of these sources ultimately will reduce streamflow.

Barlow and Leake (2012) also presented four common misconceptions about streamflow depletion from groundwater withdrawals:

- M isconception 1. Total development of groundwater resources from an aquifer system is "safe" or "sustainable" at rates as much as the average rate of recharge.
- M isconception 2. Depletion is dependent on the rate and direction of water movement in the aquifer.

- Misconception 3. Depletion stops when pumping ceases.

- Misconception 4. Pumping groundwater exclusively below a confining layer (or simply deep enough) will eliminate the possibility of depletion of surface water connected to the overlying groundwater system.

Barlow and Leake (2012) provide discussion and examples to clear up these misconceptions, but the general message from their work and others, such as Theis (1940), is that groundwater pumping will have an effect on the surrounding hydrologic system and ultimately reduce streamflow.

Ely and others (2011) determined that about one-half of the total pumping in the Yakima River Basin was met by water released from aquifer storage and one-half from streamflow reductions $\left(194 \mathrm{ft}^{3} / \mathrm{s}\right)$. The vast majority of groundwater pumping in the Yakima River Basin is downstream of the upper Kittitas County study area, however, and the Yakima River Basin groundwater model did not incorporate the hydraulic properties of the fractured bedrock. Total pumping in the upper Kittitas County study area is relatively small, with average annual pumping rates for 1992-2001 being approximately $3.5 \mathrm{ft}^{3} / \mathrm{s}$. Consumptive pumping rates are even less if septic system and hatchery return rates are considered. The small annual pumping rates should not be misconstrued to mean that pumping will have a "small" effect on the hydrologic system. The magnitude, timing, and location of the effects are a function of the magnitude, timing, and location of the withdrawals and the hydraulic properties of the surrounding aquifer system. Pumping rates tend to increase in the summer months when stream stages and groundwater levels are lowest. Also, the nature of fractures could mean a large percentage of an individual well withdrawal could be met directly and almost immediately from a highly connected stream, spring, or neighboring well. Although the total studywide reduction may seem to be small, the local effect could be relatively large. The potential effect is further complicated if the effected source is a senior water user.

Hsieh and Shapiro (1996) and Hsieh and others (1999) hypothesized that the drawdown responses, and ultimately streamflow depletion, in fractured bedrock aquifers are determined by the spatial connectivity of high transmissivity fractures. Their data suggest that over small spatial scales, variability in the hydraulic properties of different fracture systems and the degree to which fracture systems are interconnected can cause some wells to respond quickly to pumping stresses in adjacent wells where well intervals are closely connected by high transmissivity fractures. Drawdown responses may be disconnected where wells are hydraulically isolated by low-transmissivity fractures. 
Estimating the detailed effects of groundwater pumping on streamflow in any hydrologic system is difficult and intrinsic to the estimation is error and uncertainty associated with the approximations, assumptions, and simplifications that must be made. The heterogeneous and variably fractured bedrock environment that largely underlies the study area adds additional layers of complexity to understanding potential streamflow depletion. Results of this study, the USGS Yakima River Basin groundwater study (Vaccaro and others, 2009), and numerous other studies in the hydrology of fractured rocks (for example, Hsieh and Shapiro 1996; Hsieh and others, 1999) show that groundwater and surface-water are connected, and changing the stresses in one part of the system (for example, increased pumping) will have direct effects on other parts of the system (for example, reduced streamflow, reduced spring flows, and lowered water levels). Simulated water budgets from PRMS models conceptually show the availability of water, because of an abundance of recharge relative to current (2013) withdrawals. However, water availability, which is a function of the water quantity and quality in the study area, does not necessarily equate to water sustainability. Alley and others $(1999$, p. 2$)$ defined groundwater sustainability as the "development and use of ground water in a manner that can be maintained for an indefinite time without causing unacceptable environmental, economic, or social consequences." The definition of unacceptable consequences is subjective, but many would likely deem decreases in streamflow or declines in water levels over small discrete areas over a limited time (such as can occur with highly connected transmissive fractures) to be unacceptable. The availability and sustainability of groundwater is an important consideration for water resource management scenarios.

\section{Summary and Conclusions}

A study of the hydrogeology, hydrology, and geochemistry of the upper (western) 860 square miles of the Yakima River Basin in Kittitas County in central Washington was done by the U.S. Geological Survey to address concerns of stakeholders about the over-allocation of water resources in upper Kittitas County and the potential effects of additional groundwater withdrawals on existing water users and streamflows. Hydrologic, geologic, and geochemical data of the groundwater and surface-water system were collected and analyzed to define the hydrogeologic framework of upper Kittitas County, provide information about groundwater occurrence and availability, describe the extent of groundwater/surface-water interactions, and determine the potential effects on streamflow resulting from groundwater withdrawals. These data provide multiple lines of evidence for the connection between the groundwater and surface-water systems, complex groundwater flow through fractured bedrock in much of the study area, and the subbasin compartmentalization of groundwater resources. Groundwater use for the study area was estimated and a water budget for the study area and subbasins in the study area was developed.

Six hydrogeologic units were differentiated from surficial geologic units previously mapped in the study area based on their lithologic and hydraulic characteristics. These hydrogeologic units include unconsolidated sediment and five bedrock units: basalt, volcanic, sedimentary, metamorphic, and intrusive. Prior geologic mapping and lithostratigraphic information from 271 well logs were used to construct a surficial hydrogeologic unit map and 4 hydrogeologic sections showing the spatial extent and thickness of these hydrogeologic units.

The complexity of the groundwater-flow system in the upper Kittitas County study area reflects the diversity and heterogeneous distribution of the geologic materials and the spatially variable geometry of these geologic materials. Groundwater occurs under both confined and unconfined conditions. In the unconsolidated sediment unit, groundwater flows through interstitial pore space, whereas in the bedrock units, groundwater primarily occurs in fractures and other sources of secondary porosity. Groundwater movement through the fractured bedrock aquifers is particularly complex, as hydraulic properties vary considerably depending on the hydraulic conductivity and connectivity of individual fractures. A wide range of groundwater ages determined through geochemical analyses of carbon-14, sulfur hexafluoride, and tritium in groundwater, reflect this complexity. Active flushing of the shallow groundwater system is indicated by the presence of young (post-1950s) groundwater; however, components of isotopically light, Pleistocene-age groundwater with a geochemically evolved composition occur at depth within the fractured bedrock aquifers of the study area. Spatially distinct stable isotope data in the subbasins of the study area demonstrate the presence of hydrogeologically isolated subbasins where little groundwater movement occurs across subbasin boundaries.

The connection between groundwater and surface water in the upper Kittitas County study area was supported by the geochemical and hydrologic data. The isotopic content of stream water indicates connectivity to local (subbasin) groundwater resources. Groundwater sustains streamflow, but the groundwater that sustains streamflow originates in the same subbasins that contain the streams. Bulk gains and losses of streamflow were measured during a seepage run in August 2011, demonstrating that streams and rivers in the study area both gain and lose streamflow to the underlying aquifers. Thermal profiling in two streams suggests that these gains are relatively discrete and may occur over reaches of less than 1 mile long. 


\section{Acknowledgments}

The authors would like to thank the many people who contributed their time and knowledge to help complete this study. The following organizations are noted for their assistance with the collection of data and resources they provided in support of this study: Washington State Department of Ecology, Kittitas County, Yakama Nation, GSI Water Solutions, Inc., U.S. Forest Service, and the U.S. Bureau of Reclamation. In addition, the authors would like to thank the many private landowners throughout the study area that graciously provided access to their wells. The following USGS employees are gratefully acknowledged for their contributions to the study: Lisl Fasser, Zoe Futornick, Raegan Huffman, Greg Justin, James Patterson, and Karen Payne for collection of groundwater and water-quality data; Kevin Wright, Gabe Landrum, Brian Campbell, Chris Bird, and Eric Porter for measuring streamflow during the seepage run; and the many other USGS employees whose everyday efforts support this and many other studies.

\section{References Cited}

Alley, W.M, Reilly, T.E., and Franke, O.L., 1999, Sustainability of ground-water resources: U.S. Geological Survey Circular 1186, 79 p.

Barlow, P.M., and Leake, S.A., 2012, Streamflow depletion by wells-Understanding and managing the effects of groundwater pumping on streamflow: U.S. Geological Survey Circular 1376, 84 p.

Brown, E.H., 1986, Geology of the Shuksan suite, North Cascades, Washington, U.S.A. in Evans, B.W., and Brown, E.H., eds., Blueschists and eclogites: Geological Society of America Memoir 164, p. 143-154.

Brown, E.H., and Dragovich, J.D., 2003, Tectonic elements and evolution of northwest Washington: Washington State Department of Natural Resources Geologic Map GM-52; 1 sheet, scale 1:625,000; 1 pamphlet, 10 p., accessed January 16, 2012, at http://www.dnr.wa.gov/ researchscience/Pages/Publications.aspx.

Busenberg, Eurybiades, and Plummer, L.N., 2000, Dating young groundwater with sulfur hexafluoride-Natural and anthropogenic sources of sulfur hexafluoride: Water Resources Research, v. 36, p. 3,011-3,030.
Busenberg, Eurybiades, Plummer, L.N., Bartholomay, R.C., and Wayland, J.E., 1998, Chlorofluorocarbons, sulfur hexafluoride, and dissolved permanent gases in ground water from selected sites in and near the Idaho National Engineering and Environmental Laboratory, Idaho, 1994-97: U.S. Geological Survey Open-File Report 98-274, 72 p.

Buttle, J.M., 1998, Fundamentals of small catchment hydrology, in Kendall, C., and McDonnell, J.J., eds., Isotope tracers in catchment hydrology: Amsterdam, Elsevier, p. 1-49.

Carnahan, B., Luther, H.A., and Wilkes, J.O., 1969, Applied numerical methods: New York, Wiley and Sons, Inc., 604 p.

Cheney, E.S., and Hayman, N.W., 2007, Regional Tertiary sequence stratigraphy and structure on the eastern flank of the central Cascade Range, Washington, in Stelling, P., and Tucker, D., eds., Floods, faults, and fire - Geological field trips in Washington State and southwest British Columbia: Geological Society of America Field Guide 9, p. 179-208.

Clark, I.D., and Fritz, Peter, 1997, Environmental isotopes in hydrogeology: New York, Lewis Publishers, 328 p.

Clesceri, L.S., Greenberg, A.E., and Eaton, A.D., 1998, Standard methods for the examination of water and wastewater (20th ed.): Washington, D.C., American Public Health Association [variously paged].

Coplen, T.B., 1988, Normalization of oxygen and hydrogen isotope data: Chemical Geology (Isotope Geoscience Section), v. 72, p. 293-297.

Coplen, T.B., Wildman, J.D., and Chen, J., 1991, Improvements in the gaseous hydrogen-water equilibration technique for hydrogen isotope ratio analysis: Analytical Chemistry, v. 63, p. 910-912.

Cuffney, T.F., Meador, M.R., Porter, S.D., and Gurtz, M.E., 1997, Distribution of fish, benthic invertebrate, and algal communities in relation to physical and chemical conditions, Yakima River Basin, Washington, 1990: U.S. Geological Survey Water-Resources Investigations Report 96-4280, 94 p.

Dickinson, W.R., 2004, Evolution of the North American Cordillera-Annual Review of Earth and Planetary Sciences: v. 32, p. 13-45, doi:10:1145/annurev. earth.32.101802.120257. 
Dragovich, J.D., Logan, R.L., Schasse, H.W., Walsh, T.J., Lingley, W.S., Jr., Norman, D.K., Gerstel, W.J., Lapen, T.J., Schuster, J.E., and Meyers, K.D., 2002, Geologic map of Washington-Northwest quadrant: Washington State Department of Geology and Earth Resources Geologic Map GM-50, 1 sheet (scale 1:250,000) and two accompanying explanatory sheets $(52 \times 36$ in. and $40 \times 33$ in. $)$, with $72 \mathrm{p}$. text, accessed January 17, 2012, at http://www.dnr.wa.gov/ Publications/ger gm50 geol map nw wa 250k.pdf.

Driscoll, F.G., 1986, Groundwater and wells (2d ed.): St. Paul, Minnesota, Johnson Division, 1,089 p.

Drost, B.W., Whiteman, K.J., and Gonthier, J.B., 1990, Geologic framework of the Columbia Plateau Aquifer System, Washington, Oregon, and Idaho: U.S. Geological Survey Water-Resources Investigations Report 87-4238, 10 p. [Also available at http://pubs.er.usgs.gov/publication/ wri874238.]

Ely, D.M., Bachmann, M.P., and Vaccaro, J.J., 2011, Numerical simulation of groundwater flow for the Yakima River Basin aquifer system, Washington: U.S. Geological Survey Scientific Investigations Report 2011-5155, 90 p.

Fasser, E.T., and Julich, R.J., 2011, Groundwater levels for selected wells in Upper Kittitas County, Washington: U.S. Geological Survey Data Series 649.

Ferris, J.G., Knowles, D.B., Brown, R.H., and Stallman, R.W., 1962, Theory of aquifer tests: U.S. Geological Survey Water-Supply Paper 1536-E, 174 p.

Fetter, C. W., Jr., 1988, Applied hydrogeology (2d ed.): Columbus, Ohio, Charles E. Merrill and Co., 592 p.

Fishman, M.J., ed., 1993, Methods of analysis by the U.S. Geological Survey National Water Quality LaboratoryDetermination of inorganic and organic constituents in water and fluvial sediments: U.S. Geological Survey OpenFile Report 93-125, 217 p. (Also available at http://pubs. er.usgs.gov/publication/ofr93125.)

Fishman, M.J., and Friedman, L.C., 1989, Methods for determination of inorganic substances in water and fluvial sediments: U.S. Geological Survey Techniques of WaterResources Investigations, book 5, chap. A1, 545 p. (Also available at http://pubs.er.usgs.gov/publication/twri05A1.)

Freeze, R.A., and Cherry, J.A., 1979, Groundwater: Englewood Cliffs, N.J., Prentice-Hall, 604 p.
Friedman, Irving, Smith, G.I., Gleason, J.D., Warden, Augusta, and Harris, J.M., 1992, Stable isotope composition of waters in southeastern California-1. Modern precipitation: Journal of Geophysical Research-Atmospheres, v. 97, p. 5,795-5,812.

Fry, J., Xian, G., Jin, S., Dewitz, J., Homer, C., Yang, L., Barnes, C., Herold, N., and Wickham, J., 2011, Completion of the 2006 National Land Cover Database for the Conterminous United States: Photogrammetric Engineering and Remote Sensing, v. 77, no.9, p. 858-864.

Garbarino, J.R., 1999, Methods of analysis by the U.S. Geological Survey National Water Quality LaboratoryDetermination of dissolved arsenic, boron, lithium, selenium, strontium, thallium, and vanadium using inductively coupled plasma-mass spectrometry: U.S. Geological Survey Open-File Report 99-093, 31 p. (Also available at http://pubs.er.usgs.gov/publication/ofr9993.)

Garbarino, J.R., Kanagy, L.K., and Cree, M.E., 2006, Determination of elements in natural-water, biota, sediment and soil samples using collision/reaction cell inductively coupled plasma-mass spectrometry: U.S. Geological Survey Techniques and Methods, book 5, sec., chap. B1, 88 p. (Also available at http://pubs.er.usgs.gov/publication/ tm5B1.)

Gonfiantini, R., 1978, Standards for stable isotope measurements in natural compounds: Nature, v. 271, p. 534-536.

Hammond, T.B., 2009, Soil water budget and style of flow along a climate gradient on the eastern slope of the Cascade Mountains, WA using oxygen and hydrogen stable isotopes: Ellensburg, Central Washington University, M.S. thesis, 152 p.

Haugerud, R.A., and Tabor, R.W., 2009, Geologic map of the North Cascade Range, Washington: U.S. Geological Survey Scientific Investigations Map 2940, 2 sheets, scale 1:200,000; 2 pamphlets, 29 p. and 23 p., accessed January 16, 2012, at http://pubs.er.usgs.gov/publication/ $\underline{\operatorname{sim} 2940 .}$.

Healy, R.H., Winter, T.C, La Baugh, J.W., and Franke, O.L., 2007, Water budgets-Foundation for effective waterresources and environmental management: U.S. Geological Survey Circular 1308, 90 p.

Hearn, P.P., Steinkampf, W.C., Bortleson, G.C., and Drost, B.W., 1985, Geochemical controls on dissolved sodium in basalt aquifers of the Columbia Plateau, Washington: U.S. Geological Survey Water-Resources Investigations Report 84-4304, 38 p. 
Hem, J.D., 1985, Study and interpretation of the chemical characteristics of natural water (3rd ed.): U.S. Geological Survey Water-Supply Paper 2254, 264 p.

Hinkle, S.R., and Ely, D.M., 2013, Chemical and isotopic data collected from groundwater, surface-water, and atmospheric precipitation sites in upper Kittitas County, Washington, 2010-12: U.S. Geological Survey Data Series 751, http:// dx.doi.org/10.3133/ds751.

Hinkle, S.R., Shapiro, S.D., Plummer, L.N., Busenberg, Eurybiades, Widman, P.K., Casile, G.C., and Wayland, J.E., 2010, Estimates of tracer-based piston-flow ages of groundwater from selected sites: National Water-Quality Assessment Program, 1992-2005: U.S. Geological Survey Scientific Investigations Report 2010-5229, 90 p.

Hsieh, P.A., and Shapiro, A.M., 1996, Hydraulic characteristics of fractured bedrock underlying the FSE well field at the Mirror Lake site, Grafton County, New Hampshire, in Morganwalp, D.W. and Aronson, D.A., eds., U.S. Geological Survey Toxic Substances Hydrology Program-Proceedings of the technical meeting, Colorado Springs, Colo., September 20-24, 1993: U.S. Geological Survey Water-Resources Investigations Report 94-4015, v. 1 , p. $127-130$.

Hsieh, P.A., Shapiro, A.M., and Tiedeman, C., 1999, Computer simulation of fluid flow in fractured rocks at the Mirror Lake FSE well field, in Morganwalp, D.W. and Buxton, H.T., eds., U.S. Geological Survey Toxic Substances Hydrology Program-Proceedings of the technical meeting, Charleston, S.C., March 8-12, 1999: U.S. Geological Survey Water-Resources Investigations Report 99-4018C, v. 3, p. 777-781.

Jones, M.A., Vaccaro, J.J., and Watkins, A.M., 2006, Hydrogeologic framework of sedimentary deposits in six structural basins, Yakima River Basin, Washington: U.S. Geological Survey Scientific Investigations Report 2006-5116, 24 p., 7 pls., accessed September 7, 2010, at http://pubs.water.usgs.gov/sir2006-5116.

Kahle, S.C., Morgan, D.S., Welch, W.B., Ely, D.M., Hinkle, S.R., Vaccaro, J.J., and Orzol, L.L., 2011, Hydrogeologic framework and hydrologic budget components of the Columbia Plateau Regional Aquifer System, Washington, Oregon, and Idaho: U.S. Geological Survey Scientific Investigations Report 2011-5124, 66 p., http://pubs.usgs. gov/sir/2011/5124/.

Kalin, R.M., 2000, Radiocarbon dating of groundwater systems, in Cook, P.G., and Herczeg, A.L., eds., Environmental tracers in subsurface hydrology: Boston, Mass., Kluwer Academic Publishers, p. 111-144.
Kendall, Carol, and Coplen, T.B., 2001, Distribution of oxygen-18 and deuterium in river waters across the United States: Hydrological Processes, v. 15, p. 1,363-1,393.

Kittitas County, 2012, Group A and B well locations shapefile: Website, Information Technology_Geographic Information Systems, accessed January 2012 at http://www.co.kittitas. wa.us/it/gis.aspx.

Konrad, C.P., 2006, Location and timing of river-aquifer exchanges in six tributaries to the Columbia River in the Pacific Northwest of the United States: Journal of Hydrology, v. 329, p. 444-470, doi:10.1016/j. jhydrol.2006.02.028.

Lucas, L.L., and Unterweger, M.P., 2000, Comprehensive review and critical evaluation of the half-life of tritium: Journal of Research of the National Institute of Standards and Technology, v. 105, p. 541-549.

Magirl, C.S., Julich, R.J., Welch, W.B., Curran, C.R., Mastin, M.C., and Vaccaro, J.J., 2009, Summary of seepage investigations in the Yakima River basin, Washington: U.S. Geological Survey Data Series 473. (Also available at http://pubs.usgs.gov/ds/473/.)

Mastin, M.C., and Vaccaro, J.J., 2002, Watershed models for decision support in the Yakima River Basin, Washington: U.S. Geological Survey Open-File Report 02-404, 46 p. (Also available at http://pubs.usgs.gov/of/2002/ofr02404.)

McCrea, J.M., 1950, On the isotopic chemistry of carbonates and a paleotemperature scale: Journal of Chemical Physics, v. 18, p. 849-857.

Neuman, S.P., 2005, Trends, prospects and challenges in quantifying flow and transport through fractured rocks: Hydrogeology Journal, v. 13, p. 124-147.

National Oceanic and Atmospheric Administration, 2008, NOAA calibration scales for various trace gases: National Oceanic and Atmospheric Administration Web site, accessed January 18, 2013, at http://www.esrl.noaa.gov/ gmd/hats/standard/scales.html.

Oberg, K.A., Morlock, S.E., and Caldwell, W.S., 2005, Quality-assurance plan for discharge measurements using acoustic Doppler current profilers: U.S. Geological Survey Scientific Investigations Report 2005-5183, 44 p.

Omernik, J.M., 1987, Ecoregions of the conterminous United States (map supplement): Annals of the Association of American Geographers, v. 77, no. 1, p. 118-125, scale $1: 7,500,000$. 
Plummer, L.N., Eggleston, J.R., Andreasen, D.C., Raffensperger, J.P., Hunt, A.G., and Casile, G.C., 2012, Old groundwater in parts of the upper Patapsco aquifer, Atlantic Coastal Plain, Maryland, USA_Evidence from radiocarbon, chlorine-36 and helium-4: Hydrogeology Journal, v. 20, p. 1,269-1,294.

Plummer, L.N., Prestemon, E.C., and Parkhurst, D.L., 1994, An interactive code (NETPATH) for modeling NET geochemical reactions along a flow PATH, version 2.0: U.S. Geological Survey Water-Resources Investigations Report 94-4169, 130 p.

Porter, S.C., 1976, Pleistocene glaciation in the southern part of the North Cascade Range, Washington: Geological Society of America Bulletin, v. 87, p. 61-75.

Reidel, S.P., Fecht, K.R., Hagood, M.C., and Tolan, T.L., 1989, The geologic evolution of the central Columbia Plateau, in Reidel, S.P., and Hooper, P.R., eds., Volcanism and tectonism in the Columbia River flood-basalt province: Geological Society of America Special Paper 239, p. 247-264.

Reidel, S.P., Johnson, V.G., and Spane, F.A., 2002, Natural gas storage in basalt aquifers of the Columbia Basin, Pacific Northwest USA - A guide to site characterization: Richland, Wash., Pacific Northwest National Laboratory, PNNL-13962 [variously paged].

Robertson, J.A., and Gazis, C.A., 2006, An oxygen isotope study of seasonal trends in soil water fluxes at two sites along a climate gradient in Washington state (USA): Journal of Hydrology, v. 328, p. 375-387.

Sauer, V.B., and Meyer, R.W., 1992, Determination of error in individual discharge measurements: U.S. Geological Survey Open-File Report 92-144, 21 p. (Also available at http:// pubs.usgs.gov/of/1992/ofr92-144/.)

Shapiro, A.M., Hsieh, P.A., Burton, W.C., and Walsh, G.J., 2007, Integrated multi-scale characterization of groundwater flow and chemical transport in fractured crystalline rock at the Mirror Lake Site, New Hampshire, in Hyndman, D.W., Day-Lewis, F.D., and Singha, K., eds., Subsurface hydrology_-Data integration for properties and processes: American Geophysical Union Geophysical Monograph Series, v. 171, p. 201-225.

Sleeter, R., 2008, A new method for mapping population distribution: U.S. Geological Survey Fact Sheet 2008-3010, 2 p., http://pubs.usgs.gov/fs/2008/3010.

Struiver, Minze, and Polach, H.A., 1977, DiscussionReporting of 14C data: Radiocarbon, v. 19, p. 355-363.
Swanson, D.A., Anderson, J.L., Bentley, R.D., Camp, V.E., Gardner, J.N., and Wright, T.L., 1979, Reconnaissance geologic map of the Columbia River Basalt Group in Washington and adjacent Idaho: U.S. Geological Survey Open-File Report 79-1363, scale 1:250,000.

Tabor, R.W., 1994, Late Mesozoic and possible early Tertiary accretion in western Washington State-The HelenaHaystack mélange and the Darrington-Devils Mountain Fault Zone: Geological Society of America Bulletin, v. 106, no. 2, p. 217-232.

Tabor, R.W., Frizzell, V.A., Jr., Booth, D.B., and Waitt, R.B., 2000, Geologic map of the Snoqualmie Pass $30 \times 60$ minute quadrangle, Washington: U.S. Geological Survey Geologic Investigations Series I-2538, 1 sheets, scale 1:100,000; 1 pamphlet, 57 p., accessed January 16, 2012, at http://pubs. er.usgs.gov/publication/i2538.

Thatcher, L.L., 1962, The distribution of tritium fallout in precipitation over North America: Bulletin of the International Association of Scientific Hydrology, v. 7, p. 48-58.

Thatcher, L.L., Janzer, V.J., and Edwards, K.W., 1977, Methods for determination of radioactive substances in water and fluvial sediments: U.S. Geological Survey Techniques of Water-Resources Investigations, book 5, chap. A5, 95 p. (Also available at http://pubs.er.usgs.gov/ publication/twri05A5.)

Theis, C.V., 1940, The source of water derived from wellsEssential factors controlling the response of an aquifer to development: Civil Engineering, v. 10, no. 5, p. 277-280.

Tolan, T.L., Reidel, S.P., Beeson, M.H., Anderson, J.L., Fecht, K.R., and Swanson, D.A., 1989, Revisions to the estimates of the areal extent and volume of the Columbia River Basalt Group, in Reidel, S.P., and Hooper, P.R., eds., Volcanism and tectonism in the Columbia River flood-basalt province: Geological Society of America Special Paper 239, p. 1-20.

U.S. Geological Survey, 2012a, The Reston Chlorofluorocarbon Laboratory: U.S. Geological Survey Web site, accessed January 17, 2013, at http://water.usgs. gov/lab/.

U.S. Geological Survey, 2012b, Annual water-data reports: U.S. Geological Survey Web site, accessed March 15, 2013, at http://wdr.water.usgs.gov/.

U.S. Geological Survey, 2013, Reston Stable Isotope Laboratory (RSIL): U.S. Geological Survey Web site, accessed January 17, 2013, at http://isotopes.usgs.gov/. 
U.S. Geological Survey, variously dated, National field manual for the collection of water-quality data: U.S. Geological Survey Techniques of Water-Resources Investigations, book 9, chaps. A1-A9, accessed January 18, 2013, at http:// pubs.er.usgs.gov/publication/twri09.

Vaccaro, J.J., 2011, River-aquifer exchanges in the Yakima River Basin, Washington: U.S. Geological Survey Scientific Investigations Report 2011-5026, 98 p.

Vaccaro, J.J., Jones, M.A., Ely, D.M., Keys, M.E., Olsen, T.D., Welch, W.B., and Cox, S.E., 2009, Hydrogeologic framework of the Yakima River Basin Aquifer System, Washington: U.S. Geological Survey Scientific Investigations Report 2009-5152, 106 p., accessed September 7, 2010, at http://pubs.usgs.gov/sir/2009/5152.

Vaccaro, J.J., and Maloy, K.J., 2006, A thermal profile method to identify potential ground-water discharge areas and preferred salmonid habitats for long river reaches: U.S. Geological Survey Scientific Investigations Report 2006-5136, 16 p.
Vaccaro, J.J., and Sumioka, S.S., 2006, Estimates of groundwater pumpage from the Yakima River Basin Aquifer System, Washington, 1960-2000: U.S. Geological Survey Scientific Investigations Report 2006-5205, 56 p.

Washington State Department of Ecology, 2006, Washington Water Laws-A Primer: Washington State Department of Ecology, accessed May 23, 2013, at https://fortress.wa.gov/ ecy/publications/summarypages/98152.html.

Washington State Department of Ecology, 2011, GIS Data, 2010 Washington State Landuse shapefile: Washington State Department of Ecology Web site, accessed October 2011, at http://www.ecy.wa.gov/services/gis/data/data.htm.

Washington State Office of Financial Management 2012, Population, GIS data, Census 2000 and 2010 Tiger/Line files, Washington State Office of Financial Management database, accessed February 2012, at http://www.ofm. wa.gov/pop/geographic/default.asp.

Wheeler, J.D., and Eddy-Miller, C.A., 2005, Seepage investigation on selected reaches of Fish Creek, Teton County, Wyoming, 2004: U.S. Geological Survey Scientific Investigations Report 2005-5133, 15 p. (Also available at http:/pubs.usgs.gov/sir/2005/5133/.) 
Table 7. Selected physical and hydrologic data for wells, upper Yakima River Basin, Kittitas County, central Washington.

[Cross sections are shown in plate 2. USG S well No.: See diagramfor expla-tion of well-numbering system. Latitude / Longitude: Given in degrees, minutes, seconds, referenced to the North American Datum of 1983 (-D 83). L and-surface altitude: Referenced to the North American Vertical Datum of 1988 (-VD 88). H ydrogeologic unit of open interval: BAS, basalt; INT, intrusive; M, completed in multiple units; META, metamorphic; SED, sedimentary; UNC, unconsolidated sediment; UNK, unknown; VOLC, volcanic. Field inventoried: from Hinkle and Ely (2013). A bbreviations: ft, foot; ft/d, foot per day; gal/min, gallon per minute; -, not available]

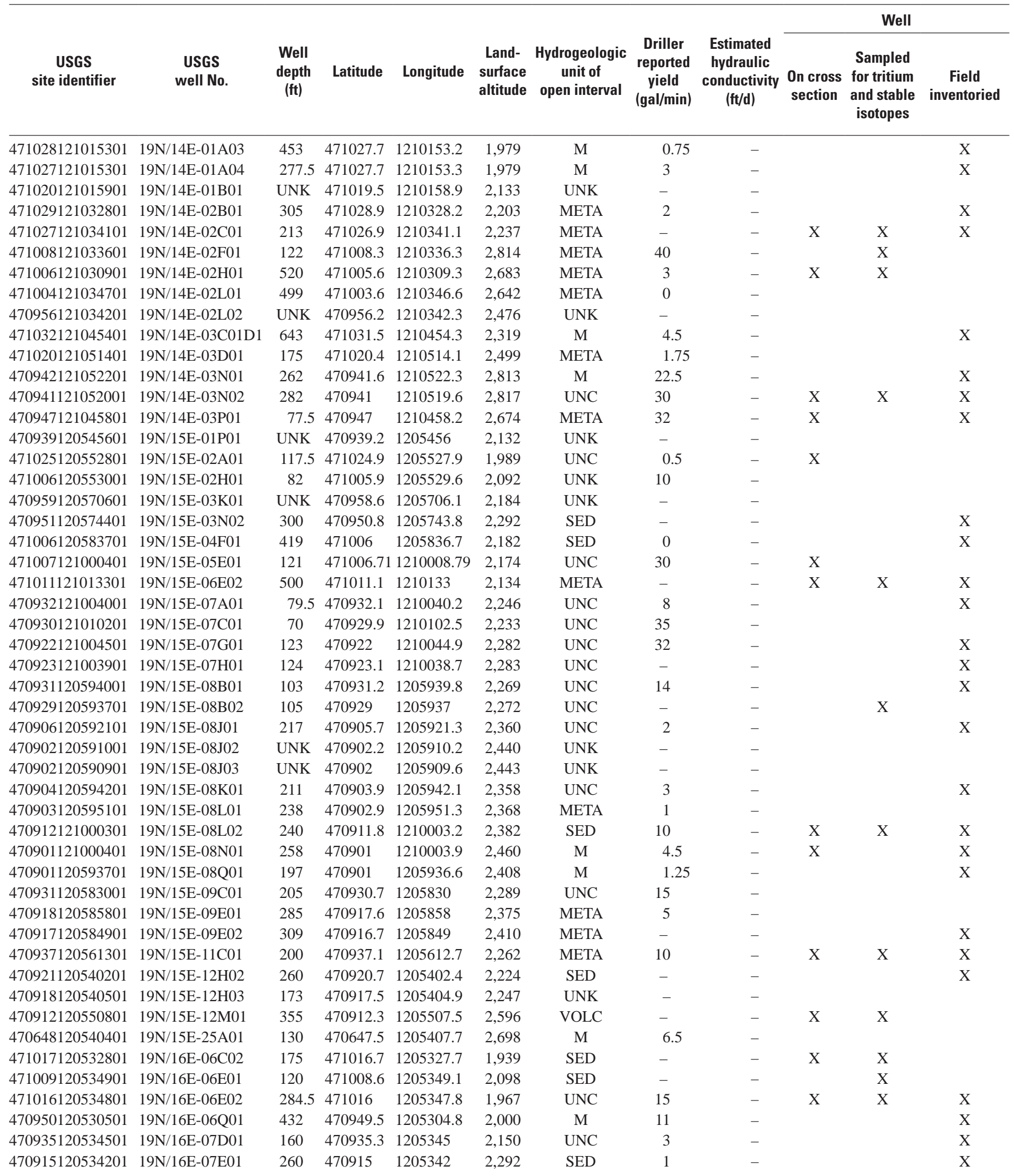


Table 7. Selected physical and hydrologic data for wells, upper Yakima River Basin, Kittitas County, central Washington.-Continued

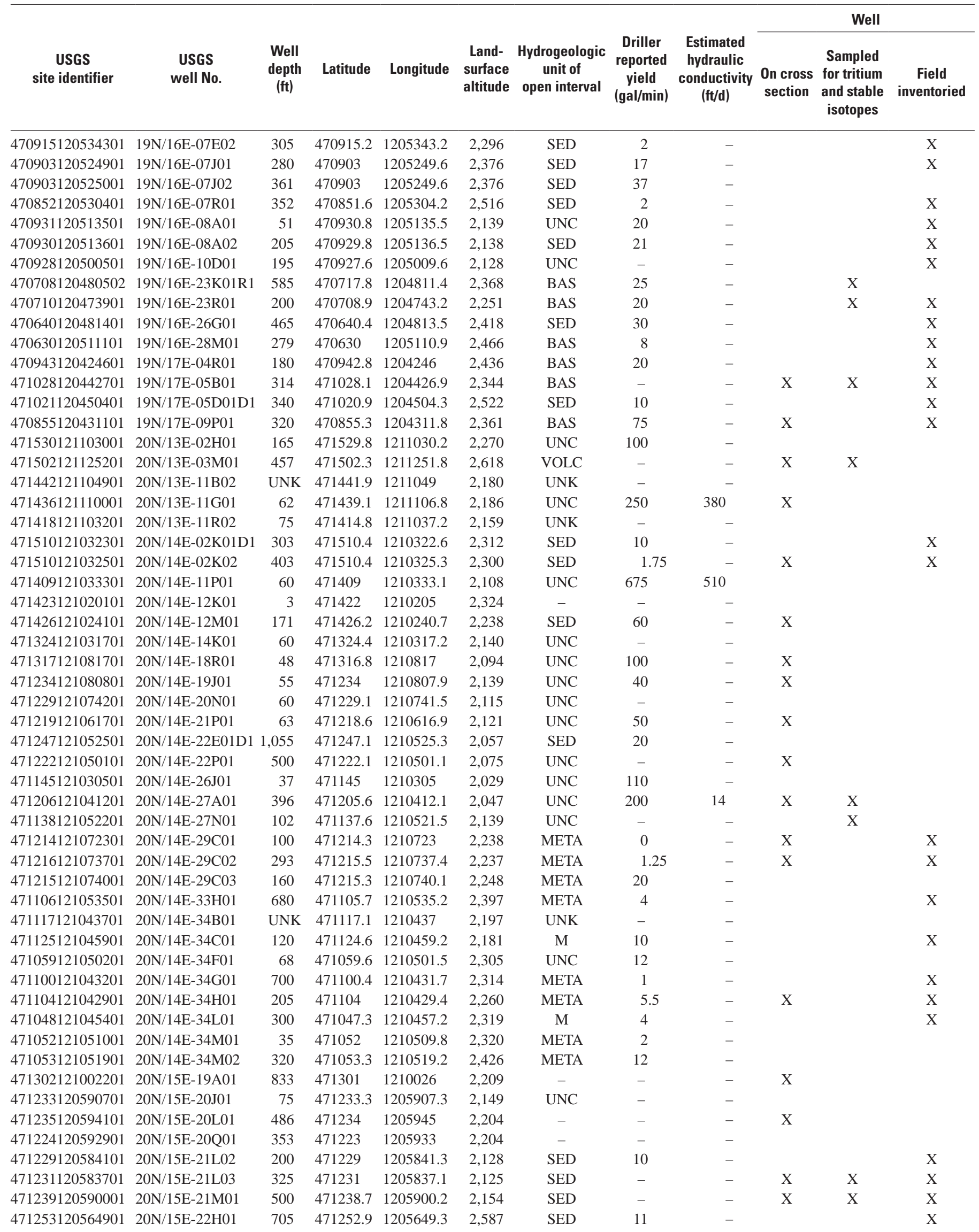


Table 7. Selected physical and hydrologic data for wells, upper Yakima River Basin, Kittitas County, central Washington.-Continued

\begin{tabular}{|c|c|c|c|c|c|c|c|c|c|c|c|}
\hline \multirow[b]{2}{*}{$\begin{array}{c}\text { USGS } \\
\text { site identifier }\end{array}$} & \multirow[b]{2}{*}{$\begin{array}{c}\text { USGS } \\
\text { well No. }\end{array}$} & \multirow[b]{2}{*}{$\begin{array}{c}\text { Well } \\
\text { depth } \\
\text { (ft) }\end{array}$} & \multirow[b]{2}{*}{ Latitude } & \multirow[b]{2}{*}{ Longitude } & \multirow[b]{2}{*}{$\begin{array}{l}\text { Land- } \\
\text { surface } \\
\text { altitude }\end{array}$} & \multirow[b]{2}{*}{$\begin{array}{c}\text { Hydrogeologic } \\
\text { unit of } \\
\text { open interval }\end{array}$} & \multirow[b]{2}{*}{$\begin{array}{c}\text { Driller } \\
\text { reported } \\
\text { yield } \\
\text { (gal } / \mathrm{min} \text { ) }\end{array}$} & \multirow[b]{2}{*}{$\begin{array}{l}\text { Estimated } \\
\text { hydraulic } \\
\text { conductivity } \\
\text { (ft/d) }\end{array}$} & \multicolumn{3}{|c|}{ Well } \\
\hline & & & & & & & & & $\begin{array}{l}\text { On cross } \\
\text { section }\end{array}$ & $\begin{array}{l}\text { Sampled } \\
\text { for tritium } \\
\text { and stable } \\
\text { isotopes }\end{array}$ & $\begin{array}{c}\text { Field } \\
\text { inventoried }\end{array}$ \\
\hline 471228120561701 & 20N/15E-23M01 & 873 & 471227.7 & 1205617.3 & 2,308 & SED & 0.75 & - & & & \\
\hline 471221120553901 & 20N/15E-23Q01 & 770 & 471221 & 1205539 & 2,371 & SED & 1.5 & - & $\mathrm{X}$ & $\mathrm{X}$ & \\
\hline 471212120540001 & 20N/15E-25A01 & 180 & 471212.3 & 1205400 & 2,353 & SED & - & - & & & $\mathrm{X}$ \\
\hline 471132120543901 & 20N/15E-25P01 & 10.1 & 471131 & 1205443 & 1,891 & UNC & - & - & & & \\
\hline 471154120553201 & 20N/15E-26H01 & 180 & 471153.6 & 1205532.1 & 2,013 & SED & - & - & & $\mathrm{X}$ & $\mathrm{X}$ \\
\hline 471129120562501 & 20N/15E-26N01 & 608 & 471128 & 1205629 & 1,910 & - & - & - & $\mathrm{X}$ & & \\
\hline 471143120563501 & 20N/15E-27J01 & 840 & 471142 & 1205639 & 1,924 & - & - & - & $\mathrm{X}$ & & \\
\hline 471142120571502 & 20N/15E-27L02 & 1,170 & 471141 & 1205719 & 1,984 & - & - & - & & & \\
\hline 471128120581501 & 20N/15E-28Q01 & 160 & 471127.7 & 1205819.4 & 1,964 & UNC & 1,460 & 130 & $\mathrm{X}$ & & \\
\hline 471132120580401 & 20N/15E-28Q04 & 225 & 471132.3 & 1205810.4 & 2,015 & UNC & 200 & - & & & \\
\hline 471131120575601 & 20N/15E-28R01 & 215 & 471130 & 1205759.9 & 1,924 & UNC & 1,600 & 100 & $\mathrm{X}$ & & \\
\hline 471137120575201 & 20N/15E-28R03 & 220 & 471136.4 & 1205755.8 & 2,000 & UNC & - & - & & & \\
\hline 471210120591001 & 20N/15E-29A01 & 216 & 471209 & 1205914 & 2,189 & - & - & - & & & \\
\hline 471127121005701 & 20N/15E-30Q01 & 40 & 471127 & 1210056.8 & 1,985 & UNC & 250 & - & & & \\
\hline 471059121013401 & 20N/15E-31E02 & 273 & 471059.7 & 1210133.6 & 2,000 & UNC & 51 & - & & & $\mathrm{X}$ \\
\hline 471056121004101 & 20N/15E-31K01 & 216 & 471056.5 & 1210049.2 & 1,976 & UNC & 40 & 4.4 & & & \\
\hline 471112121000701 & 20N/15E-32D01 & 22 & 471112 & 1210006.7 & 1,979 & UNC & 28 & - & & $\mathrm{X}$ & \\
\hline 471115121000901 & 20N/15E-32D02 & 43.5 & 471114.7 & 1210008.7 & 1,979 & UNC & 40 & - & & & \\
\hline 471115120584301 & 20N/15E-33D01 & 516 & 471114 & 1205847 & 1,949 & - & - & - & $\mathrm{X}$ & & \\
\hline 471103120585101 & 20N/15E-33E01 & 374 & 471102 & 1205855 & 1,937 & - & - & - & $\mathrm{X}$ & & \\
\hline 471516120520601 & 20N/16E-05F01 & 300 & 471516.5 & 1205206.3 & 2,206 & SED & 4 & - & $\mathrm{X}$ & $\mathrm{X}$ & $\mathrm{X}$ \\
\hline 471518120521201 & 20N/16E-05F02 & 140 & 471517.9 & 1205212.2 & 2,235 & SED & 76 & - & & & $\mathrm{X}$ \\
\hline 471504120515501 & 20N/16E-05K01 & 200 & 471503.5 & 1205154.7 & 2,189 & SED & 25 & - & $\mathrm{X}$ & & $\mathrm{X}$ \\
\hline 471535120534701 & 20N/16E-06D01 & 87 & 471535.4 & 1205347.5 & 2,271 & SED & 7 & - & & & $\mathrm{X}$ \\
\hline 471435120492201 & 20N/16E-10B01 & 504 & 471435.4 & 1204922.5 & 2,161 & SED & 3 & - & $\mathrm{X}$ & $\mathrm{X}$ & $\mathrm{X}$ \\
\hline 471432120495101 & 20N/16E-10E01 & 140 & 471432.5 & 1204951.3 & 2,118 & SED & 20 & - & $\mathrm{X}$ & $\mathrm{X}$ & $\mathrm{X}$ \\
\hline 471427120492701 & 20N/16E-10G01 & 400 & 471426.6 & 1204926.6 & 2,144 & SED & 4.5 & - & $\mathrm{X}$ & & $\mathrm{X}$ \\
\hline 471408120492701 & 20N/16E-10Q01 & 12 & 471408.6 & 1204926.6 & 2,081 & UNC & 220 & 240 & $\mathrm{X}$ & $\mathrm{X}$ & $\mathrm{X}$ \\
\hline 471347120480901 & 20N/16E-14B01 & 465 & 471346.5 & 1204809 & 2,126 & SED & - & - & $\mathrm{X}$ & $\mathrm{X}$ & $\mathrm{X}$ \\
\hline 471340120474001 & 20N/16E-14H01 & 165 & 471340.5 & 1204741.1 & 2,120 & SED & 50 & - & $\mathrm{X}$ & $\mathrm{X}$ & $\mathrm{X}$ \\
\hline 471257120465601 & 20N/16E-24B01 & 245 & 471256.9 & 1204656.2 & 1,993 & SED & 4.5 & - & $\mathrm{X}$ & & $\mathrm{X}$ \\
\hline 471246120464601 & 20N/16E-24G01 & 245 & 471246 & 1204645.9 & 1,978 & SED & 4 & - & $\mathrm{X}$ & $\mathrm{X}$ & \\
\hline 471224120464001 & 20N/16E-24Q01 & 400 & 471223 & 1204644 & 1,964 & SED & 7.5 & - & $\mathrm{X}$ & $\mathrm{X}$ & $\mathrm{X}$ \\
\hline 471219120465901 & 20N/16E-24Q02D1 & 510 & 471218.8 & 1204659.1 & 2,076 & SED & 13 & - & & $\mathrm{X}$ & $\mathrm{X}$ \\
\hline 471225120462401 & 20N/16E-24R01 & 405 & 471225.4 & 1204624.3 & 2,004 & SED & 5 & - & & & $\mathrm{X}$ \\
\hline 471149120464501 & 20N/16E-25G01 & 105 & 471149.2 & 1204645.4 & 1,938 & SED & 3.5 & - & $\mathrm{X}$ & $\mathrm{X}$ & $\mathrm{X}$ \\
\hline 471154120465401 & 20N/16E-25G02 & 205 & 471153.8 & 1204653.5 & 1,935 & SED & - & - & $\mathrm{X}$ & $\mathrm{X}$ & $\mathrm{X}$ \\
\hline 471147120462501 & 20N/16E-25H01 & 69 & 471147.3 & 1204625.4 & 2,003 & UNC & - & - & $\mathrm{X}$ & $\mathrm{X}$ & $\mathrm{X}$ \\
\hline 471140120482801 & 20N/16E-26L01 & 240 & 471140.3 & 1204827.5 & 1,906 & SED & 32 & - & & & $\mathrm{X}$ \\
\hline 471142120484601 & 20N/16E-26M01 & 165 & 471141 & 1204850.1 & 1,931 & SED & 30 & - & & $\mathrm{X}$ & $\mathrm{X}$ \\
\hline 471136120484201 & 20N/16E-26M02 & 200 & 471135.8 & 1204842.5 & 1,906 & SED & - & - & & $\mathrm{X}$ & $\mathrm{X}$ \\
\hline 471145120483601 & 20N/16E-26M03 & 303 & 471145.3 & 1204835.6 & 1,918 & SED & - & - & & $\mathrm{X}$ & $\mathrm{X}$ \\
\hline 471135120510101 & 20N/16E-28P01 & 190 & 471134.5 & 1205105.2 & 1,925 & UNC & - & - & & $\mathrm{X}$ & \\
\hline
\end{tabular}


Table 7. Selected physical and hydrologic data for wells, upper Yakima River Basin, Kittitas County, central Washington.-Continued

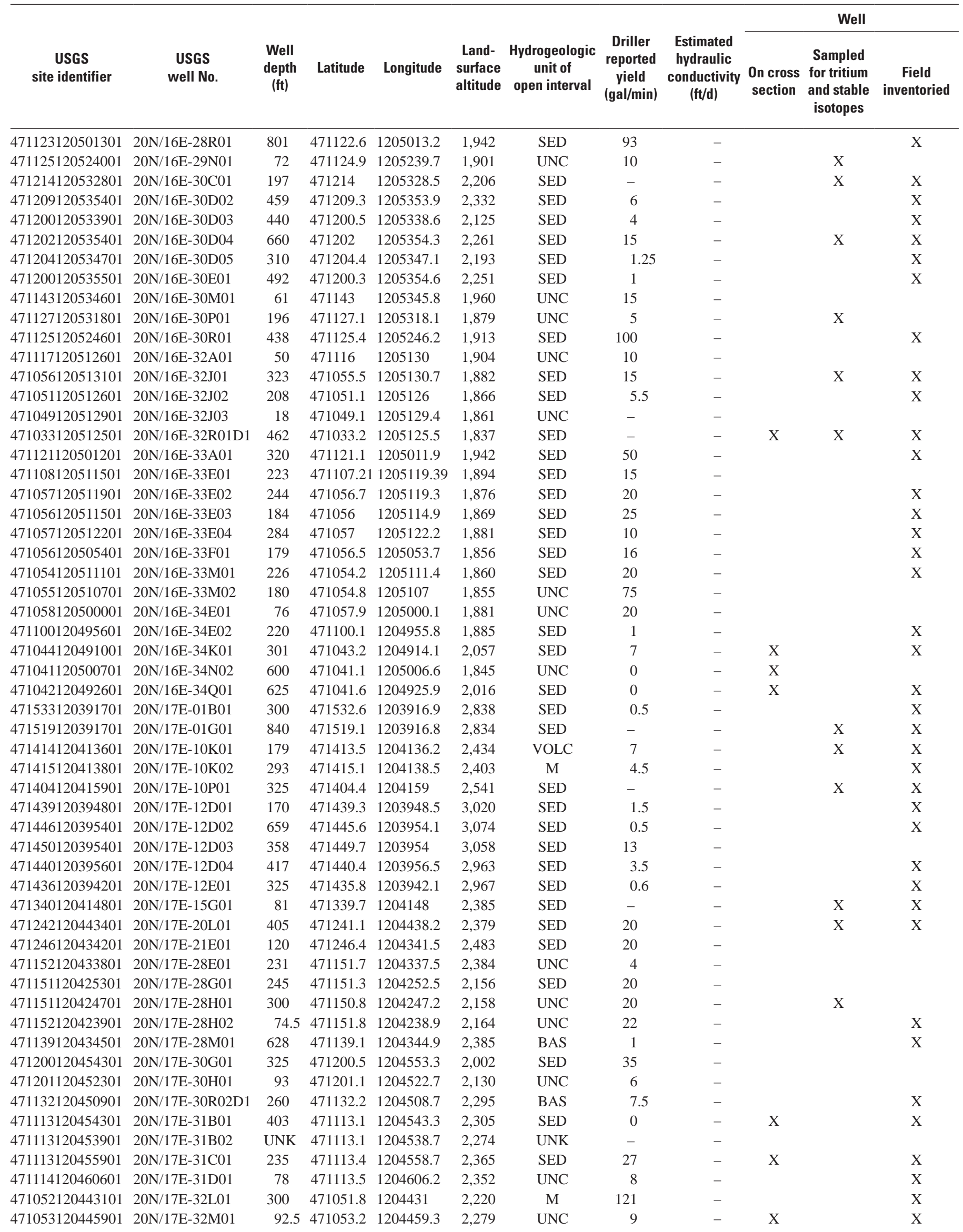


Table 7. Selected physical and hydrologic data for wells, upper Yakima River Basin, Kittitas County, central Washington.-Continued

\begin{tabular}{|c|c|c|c|c|c|c|c|c|c|c|c|}
\hline \multirow[b]{2}{*}{$\begin{array}{c}\text { USGS } \\
\text { site identifier }\end{array}$} & \multirow[b]{2}{*}{$\begin{array}{c}\text { USGS } \\
\text { well No. }\end{array}$} & \multirow[b]{2}{*}{$\begin{array}{c}\text { Well } \\
\text { depth } \\
\text { (ft) }\end{array}$} & \multirow[b]{2}{*}{ Latitude } & \multirow[b]{2}{*}{ Longitude } & \multirow[b]{2}{*}{$\begin{array}{l}\text { Land- } \\
\text { surface } \\
\text { altitude }\end{array}$} & \multirow[b]{2}{*}{$\begin{array}{l}\text { Hydrogeologic } \\
\text { unit of } \\
\text { open interval }\end{array}$} & \multirow[b]{2}{*}{$\begin{array}{c}\text { Driller } \\
\text { reported } \\
\text { yield } \\
\text { (gal } / \text { min) }\end{array}$} & \multirow[b]{2}{*}{$\begin{array}{c}\text { Estimated } \\
\text { hydraulic } \\
\text { conductivity } \\
\text { (ft/d) }\end{array}$} & \multicolumn{3}{|c|}{ Well } \\
\hline & & & & & & & & & $\begin{array}{l}\text { On cross } \\
\text { section }\end{array}$ & $\begin{array}{c}\text { Sampled } \\
\text { for tritium } \\
\text { and stable } \\
\text { isotopes }\end{array}$ & $\begin{array}{c}\text { Field } \\
\text { inventoried }\end{array}$ \\
\hline 471040120442201 & 20N/17E-32Q01 & 239 & 471039.9 & 1204422 & 2,209 & BAS & 15 & - & & & $\mathrm{x}$ \\
\hline 471035120440001 & 20N/17E-32R01 & 160 & 471035 & 1204400.1 & 2,094 & UNC & 20 & - & & & $\mathrm{x}$ \\
\hline 471903121162801 & 21N/12E-13A01 & 443 & 471903 & 1211627.6 & 2,432 & VOLC & 8 & - & & & \\
\hline 471859121163601 & 21N/12E-13A02 & 304 & 471858.6 & 1211636 & 2,465 & VOLC & 25 & - & & & $\mathrm{x}$ \\
\hline 471902121163501 & 21N/12E-13A03 & 304 & 471901.5 & 1211634.6 & 2,443 & VOLC & 20 & - & & & \\
\hline 471836121184101 & 21N/12E-14N01 & 71 & 471831 & 1211845.6 & 2,397 & UNC & 100 & - & & & \\
\hline 471814121192201 & 21N/12E-22A01 & 200 & 471807.3 & 1211917 & 2,476 & VOLC & 3 & 0.02 & $\mathrm{X}$ & & \\
\hline 471808121194001 & 21N/12E-22C01 & 370 & 471808.3 & 1211939.9 & 2,508 & VOLC & - & - & $\mathrm{X}$ & $\mathrm{X}$ & $\mathrm{X}$ \\
\hline 471758121171101 & 21N/12E-24F01 & 80 & 471757.5 & 1211711.3 & 2,535 & SED & 3 & - & & & $\mathrm{x}$ \\
\hline 471613121165201 & 21N/12E-36G01 & 47 & 471613 & 1211651.9 & 2,305 & UNC & 42 & - & $\mathrm{X}$ & & \\
\hline 471552121170001 & 21N/12E-36Q01 & 240 & 471552.4 & 1211659.7 & 2,277 & M & - & - & $\mathrm{X}$ & $\mathrm{X}$ & \\
\hline 471938121161001 & 21N/13E-07E01 & 218 & 471937.8 & 1211609.7 & 2,418 & SED & 5 & - & & & $\mathrm{X}$ \\
\hline 471939121153001 & 21N/13E-07G01 & 400 & 471939.1 & 1211530.1 & 2,472 & VOLC & 42 & - & & $\mathrm{X}$ & \\
\hline 471946121153001 & 21N/13E-07G02 & 497 & 471945.7 & 1211530 & 2,433 & SED & 1 & - & & & $\mathrm{x}$ \\
\hline 471947121154201 & 21N/13E-07G03D1 & 472 & 471947.2 & 1211541.9 & 2,360 & SED & 0.75 & - & & & $\mathrm{x}$ \\
\hline 471935121152401 & 21N/13E-07J01 & 155 & 471934.7 & 1211524.2 & 2,457 & SED & 17 & - & & & $\mathrm{x}$ \\
\hline 471930121161301 & 21N/13E-07M01 & 260 & 471930.1 & 1211612.6 & 2,413 & VOLC & 14.5 & - & & & $\mathrm{X}$ \\
\hline 471803121125101 & 21N/13E-21H01 & 175 & 471802.9 & 1211250.7 & 2,319 & SED & - & - & & $\mathrm{x}$ & $\mathrm{x}$ \\
\hline 471727121134601 & 21N/13E-21N01 & 280 & 471726.9 & 1211346.1 & 2,307 & SED & 3 & - & & & \\
\hline 471941121061701 & 21N/14E-08H01D1 & 104 & 471940.6 & 1210617.1 & 2,279 & VOLC & 40 & - & & & \\
\hline 471938121061701 & 21N/14E-08H02 & 423 & 471937.6 & 1210616.9 & 2,280 & UNC & 8 & - & $\mathrm{X}$ & & $\mathrm{x}$ \\
\hline 471933121054201 & 21N/14E-09F01 & 350 & 471933.4 & 1210541.9 & 2,911 & VOLC & 16 & - & & & $\mathrm{X}$ \\
\hline 471931121055601 & 21N/14E-09M01 & 198 & 471930.8 & 1210555.8 & 2,599 & VOLC & 12 & - & $\mathrm{X}$ & & $\mathrm{x}$ \\
\hline 471911121060601 & 21N/14E-09N01 & 251 & 471911.2 & 1210605.6 & 2,309 & VOLC & 20 & - & & & \\
\hline 471914121055201 & 21N/14E-09P01 & 658 & 471913.8 & 1210551.7 & 2,575 & M & 12 & - & $\mathrm{x}$ & & $\mathrm{X}$ \\
\hline 471906121054301 & 21N/14E-16C01 & 400 & 471905.5 & 1210542.7 & 2,649 & SED & 11 & - & & & $\mathrm{x}$ \\
\hline 471906121054201 & 21N/14E-16C02 & 500 & 471905.5 & 1210542.7 & 2,650 & SED & 1.5 & - & $\mathrm{X}$ & & $\mathrm{x}$ \\
\hline 471901121054501 & 21N/14E-16C03 & 317 & 471901.2 & 1210544.6 & 2,618 & SED & 5 & - & $\mathrm{X}$ & & $\mathrm{x}$ \\
\hline 471824121055501 & 21N/14E-16P01 & 510 & 471823.9 & 1210554.7 & 2,465 & M & 5.5 & - & $\mathrm{X}$ & & \\
\hline 471824121054801 & 21N/14E-16P02 & 193 & 471824.1 & 1210548.3 & 2,586 & VOLC & 30 & - & & & \\
\hline 471725121054401 & 21N/14E-21P01 & 520 & 471724.8 & 1210548.4 & 2,371 & VOLC & 10 & - & $\mathrm{x}$ & $\mathrm{X}$ & $\mathrm{x}$ \\
\hline 471645121050501 & 21N/14E-28R01 & 220 & 471640.7 & 1210458.4 & 2,290 & SED & 50 & 1.6 & $\mathrm{X}$ & & $\mathrm{x}$ \\
\hline 471612121035601 & 21N/14E-34H02 & 285 & 471612.3 & 1210356.3 & 2,375 & SED & 10 & - & & & $\mathrm{X}$ \\
\hline 471612121035101 & 21N/14E-34H03 & 345 & 471612 & 1210351.2 & 2,399 & SED & 5 & - & $\mathrm{X}$ & & $\mathrm{x}$ \\
\hline 471612121035901 & 21N/14E-34H04 & 300 & 471612.2 & 1210359.1 & 2,374 & SED & 11 & - & & & \\
\hline 471546121034501 & 21N/14E-34R01 & 664 & 471546 & 1210344.8 & 2,302 & SED & - & - & $\mathrm{X}$ & $\mathrm{X}$ & $\mathrm{X}$ \\
\hline 471542121031001 & 21N/14E-35P01 & 474 & 471542.3 & 1210309.6 & 2,833 & SED & 3 & - & & & $\mathrm{x}$ \\
\hline 471711120554001 & 21N/15E-26C01 & 345 & 471710.9 & 1205539.8 & 2,597 & SED & 4 & - & $\mathrm{X}$ & & $\mathrm{x}$ \\
\hline 471703120553101 & 21N/15E-26F01 & 270 & 471702.8 & 1205530.9 & 2,554 & SED & 15 & - & $\mathrm{X}$ & & $\mathrm{x}$ \\
\hline 471554120530801 & 21N/16E-31E01 & 358 & 471553.5 & 1205307.6 & 2,321 & SED & 3 & - & $\mathrm{X}$ & & $\mathrm{x}$ \\
\hline 471554120525401 & 21N/16E-31K01 & 665 & 471554.3 & 1205254 & 2,266 & SED & - & - & & & $\mathrm{x}$ \\
\hline 471555120525801 & 21N/16E-31K02 & 580 & 471555.2 & 1205257.5 & 2,290 & SED & 2.5 & - & & & $\mathrm{x}$ \\
\hline 471551120525701 & 21N/16E-31K03 & 282 & 471551.4 & 1205257.3 & 2,283 & SED & 3.5 & - & $\mathrm{X}$ & & $\mathrm{X}$ \\
\hline 471547120530601 & 21N/16E-31P01 & 118 & 471547.3 & 1205305.8 & 2,304 & SED & 9 & - & & & $\mathrm{x}$ \\
\hline 471818120433901 & 21N/17E-22N01 & 75 & 471727.7 & 1204203.1 & 2,743 & SED & 12 & 3.6 & & & \\
\hline 471727120415601 & 21N/17E-22P02 & 135 & 471727 & 1204155.5 & 2,748 & SED & 15 & - & & & $\mathrm{X}$ \\
\hline 471602120383201 & 21N/17E-36J01 & 60 & 471601.7 & 1203832 & 3,111 & VOLC & 20 & - & & & $\mathrm{x}$ \\
\hline 471830120374401 & 21N/18E-18K01 & 215 & 471830.2 & 1203743.9 & 4,361 & SED & 29 & - & & & $\mathrm{x}$ \\
\hline 471826120373501 & 21N/18E-18Q01 & 99 & 471825.6 & 1203735.4 & 4,222 & SED & 24 & - & & & \\
\hline 472403121055801 & 22N/14E-16D01 & 76 & 472402.8 & 1210557.7 & 2,379 & UNC & 40 & 1,600 & & $\mathrm{X}$ & \\
\hline 472358121053401 & 22N/14E-16G01 & 74 & 472357.7 & 1210533.7 & 2,416 & UNC & 29 & 930 & & & \\
\hline 472104121061501 & 22N/14E-32J01 & 60 & 472104 & 1210618.2 & 2,257 & UNC & 100 & - & $\mathrm{X}$ & & \\
\hline 472613121032201 & 23N/14E-35M01 & 317 & 472613.4 & 1210322.3 & 2,938 & INT & 0 & - & & & $\mathrm{X}$ \\
\hline 472611121033101 & 23N/14E-35M02 & 132.5 & 472610.6 & 1210330.6 & 2,845 & INT & 5 & - & & $\mathrm{X}$ & $\mathrm{x}$ \\
\hline 472615121033601 & 23N/14E-35M03 & 52 & 472615.2 & 1210336.5 & 2,776 & INT & 60 & - & & & $\mathrm{x}$ \\
\hline
\end{tabular}





\section{Glossary}

Age Dating The age of groundwater is defined as the time it takes for a parcel of water to go from the water table to a downgradient measurement point (such as a well). Knowledge of groundwater age is essential to the determination of rates of groundwater movement, estimating rates of contaminant attenuation, and quantifying recharge rates. Hydrologists can estimate groundwater time of travel ("age dating”) by measuring concentrations of environmental tracers (certain widespread elements, compounds, or isotopes) in groundwater and relating changes in environmental tracers to time-changing atmospheric inputs or timechanging properties of those environmental tracers. The term "environmental" indicates widespread occurrence, as compared with a local-spatial-scale tracer injection used to understand tracer movement at one particular study site. In practice, the tracer (not the water) is dated. Groundwater mixing can complicate age dating.

Major Dissolved Gases The major dissolved gases in this report include nitrogen $\left(\mathrm{N}_{2}\right)$, oxygen $\left(\mathrm{O}_{2}\right)$, argon $(\mathrm{Ar})$, methane $\left(\mathrm{CH}_{4}\right)$, and carbon dioxide $\left(\mathrm{CO}_{2}\right)$. Four of these gases $\left(\mathrm{N}_{2}, \mathrm{O}_{2}\right.$, Ar, and $\left.\mathrm{CO}_{2}\right)$ are the volumetrically dominant gases in dry atmosphere and are incorporated into groundwater during recharge. Non-atmospheric $\mathrm{CO}_{2}$ is incorporated into groundwater (for example, from root respiration and from reduction/ oxidation, or redox, reactions), generally at concentrations considerably greater than those from atmospheric sources. Dissolved methane can be incorporated into groundwater as a result of redox reactions; although $\mathrm{CH}_{4}$ is not ubiquitously detected in groundwater, $\mathrm{CH}_{4}$ concentrations often become a volumetrically major dissolved gas. These five gases, often analyzed as a suite, can be used to infer recharge temperatures $\left(\mathrm{N}_{2}, \mathrm{Ar}\right)$, oxidation/ reduction state $\left(\mathrm{O}_{2}, \mathrm{CH}_{4}\right)$, and excess $\mathrm{N}_{2}$ from denitrification.

Piston Flow Piston flow is a term used to describe the manner in which groundwater flow can be conceptualized. The basic assumption of piston flow is that all water (and solutes) arriving at a sampling location, such as a well, follows the same path.

Conceptually, this is similar to flow through a pipe.

$\mathbf{S F}_{6} \quad$ Sulfur hexafluoride $\left(\mathrm{SF}_{6}\right)$ is a compound that has both natural and anthropogenic sources. Sulfur hexafluoride volatilizes into the atmosphere, and subsequently partitions into water that is in contact with the atmosphere. Sulfur hexafluoride concentrations have been increasing over time, facilitating the use of $\mathrm{SF}_{6}$ in age-dating applications where natural sources of $\mathrm{SF}_{6}$ are absent or negligible. 

Publishing support provided by the U.S. Geological Survey

Publishing Network, Tacoma Publishing Service Center

For more information concerning the research in this report, contact the Director, Washington Water Science Center

U.S. Geological Survey

934 Broadway, Suite 300

Tacoma, Washington 98402

http://wa.water.usgs.gov 
